\title{
Addendum to \\ Industrial Market Assessment of the Products of Mild Gasification
}

Topical Report

Work Performed Under Contract No.: DE-AC21-87MC24267

\section{For}

U.S. Department of Energy Office of Fossil Energy Morgantown Energy Technology Center

P.0. Box 880

Morgantown, West Virginia 26507-0880

\author{
By \\ University of North Dakota \\ Energy and Environmental Research Center \\ Box 8213 \\ University Station \\ Grand Forks, North Dakota 58202 \\ and \\ J.E. Sinor Consultants, Inc. \\ Niwot, Colorado 80544 \\ May 1992
}




\section{TABLE OF CONTENTS}

$\underline{\text { Page }}$

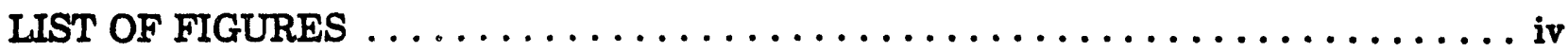

LIST OF TABLES $\ldots \ldots \ldots \ldots \ldots \ldots \ldots \ldots \ldots \ldots \ldots \ldots \ldots \ldots \ldots \ldots \ldots \ldots$

1.0 INTRODUCTION $\ldots \ldots \ldots \ldots \ldots \ldots \ldots \ldots \ldots \ldots \ldots \ldots \ldots \ldots \ldots \ldots$

2.0 MARKET OPPORTUNITIES FOR MIID GASIFICATION CHAR ........ 2

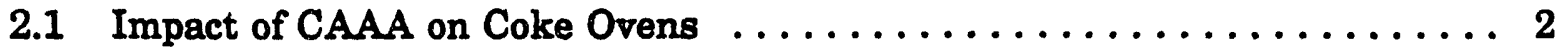

2.2 Impact of CAAA on Electric Utilities $\ldots \ldots \ldots \ldots \ldots \ldots \ldots \ldots \ldots \ldots, 2$

2.3 Impact of CAAA on Municipal Waste Combustors $\ldots \ldots \ldots \ldots \ldots \ldots \ldots 2$

2.4 Market for MGP Activated Carbon $\ldots \ldots \ldots \ldots \ldots \ldots \ldots \ldots \ldots \ldots, 2$

3.0 THE CLEAN AIR ACT AMENDMENTS OF 1990 AS THEY AFFECT THE COKE AND STEEL INDUSTRY $\ldots \ldots \ldots \ldots \ldots \ldots \ldots \ldots \ldots \ldots \ldots$

3.1 The MACT Option $\ldots \ldots \ldots \ldots \ldots \ldots \ldots \ldots \ldots \ldots \ldots \ldots \ldots \ldots \ldots$

3.2 The "Extension Track" Option $\ldots \ldots \ldots \ldots \ldots \ldots \ldots \ldots \ldots \ldots \ldots \ldots$

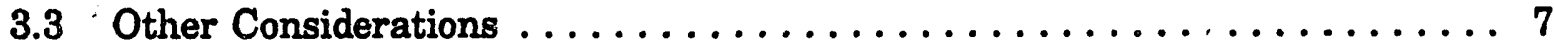

4.0 STRUCTURE OF THE COKE INDUSTRY $\ldots \ldots \ldots \ldots \ldots \ldots \ldots \ldots, \ldots$

4.1 The Merchant Coke Industry $\ldots \ldots \ldots \ldots \ldots \ldots \ldots \ldots \ldots \ldots, 14$

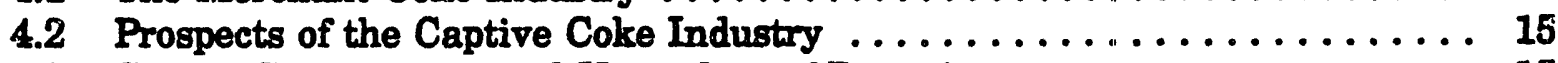

4.3 Cost of Construction and Upgrading of Batteries $\ldots \ldots \ldots \ldots \ldots \ldots \ldots 15$

5.0 ESTIMATE OF THE COKE SHORTFALL $\ldots \ldots \ldots \ldots \ldots \ldots \ldots \ldots \ldots, 17$

5.1 Alternative for Replacement of the Coke Shortfall $\ldots \ldots \ldots \ldots \ldots \ldots \ldots 21$

5.2 Loss of By-Products $\ldots \ldots \ldots \ldots \ldots \ldots \ldots \ldots \ldots \ldots \ldots \ldots \ldots \ldots \ldots, 22$

5.3 Coke Value $\ldots \ldots \ldots \ldots \ldots \ldots \ldots \ldots \ldots \ldots \ldots \ldots \ldots \ldots, 23$

6.0 COMPETTTION ANALYSTS $\ldots \ldots \ldots \ldots \ldots \ldots \ldots \ldots \ldots \ldots \ldots \ldots \ldots \ldots \ldots, 24$

6.1 Less Polluting Cokemaking Processes $\ldots \ldots \ldots \ldots \ldots \ldots \ldots \ldots \ldots, 24$

6.1.1 Nonrecovery Coking $\ldots \ldots \ldots \ldots \ldots \ldots \ldots \ldots \ldots \ldots \ldots, 24$

6.1.2 Formcoke $\ldots \ldots \ldots \ldots \ldots \ldots \ldots \ldots \ldots \ldots \ldots \ldots \ldots \ldots \ldots \ldots \ldots \ldots \ldots, 25$

6.1.3 Jumbo Coking $\ldots \ldots \ldots \ldots \ldots \ldots \ldots \ldots \ldots \ldots \ldots \ldots \ldots \ldots \ldots \ldots, 27$

6.1.4 Advanced Formcoking $\ldots \ldots \ldots \ldots \ldots \ldots \ldots \ldots \ldots \ldots \ldots \ldots \ldots \ldots, 27$

6.1.5 Other Findings $\ldots \ldots \ldots \ldots \ldots \ldots \ldots \ldots \ldots \ldots \ldots \ldots \ldots \ldots$

7.0 NONCOKING PROCESSES FOR MAKING STEEL $\ldots \ldots \ldots \ldots \ldots \ldots, 30$

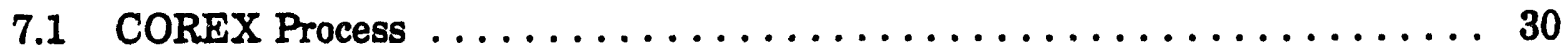

7.2 Other Direct Smelting Processes $\ldots \ldots \ldots \ldots \ldots \ldots \ldots \ldots \ldots \ldots, 30$

7.3 Direct-Reduced Iron $\ldots \ldots \ldots \ldots \ldots \ldots \ldots \ldots \ldots \ldots \ldots \ldots \ldots \ldots \ldots \ldots \ldots$

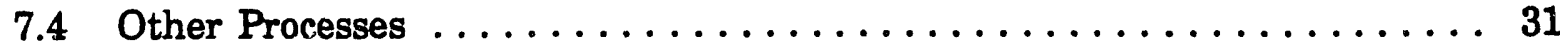

7.5 Summary $\ldots \ldots \ldots \ldots \ldots \ldots \ldots \ldots \ldots \ldots \ldots \ldots \ldots \ldots \ldots \ldots \ldots \ldots, 31$ 
8.0 MGP FORMCOKE MARKET OPPORTUNITY $\ldots \ldots \ldots \ldots \ldots \ldots \ldots \ldots \ldots$

$\ldots \ldots \ldots \ldots \ldots \ldots$

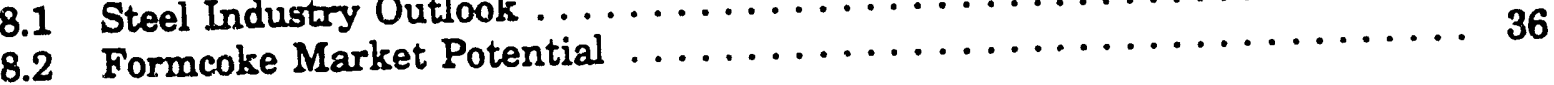

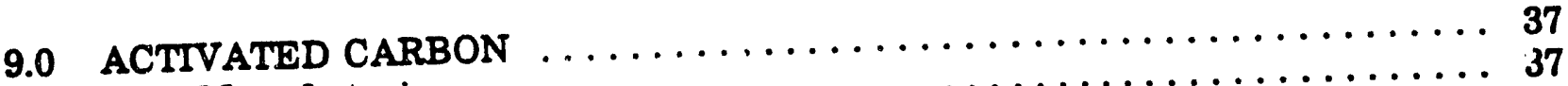

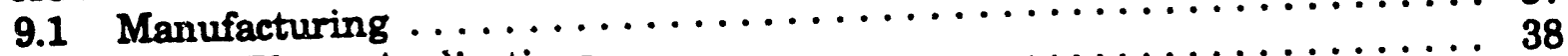

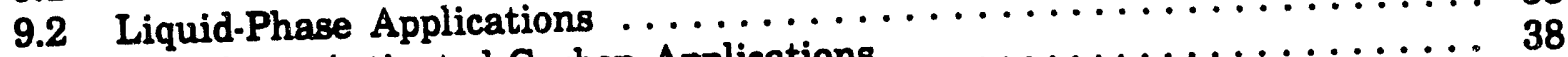

9.3 Gas-Phase Activated Carbon Applications $\ldots \ldots \ldots \ldots \ldots \ldots \ldots \ldots \ldots \ldots \ldots$

9.4 United States Production of Activated Carbon $\ldots \ldots \ldots \ldots \ldots \ldots \ldots \ldots \ldots$

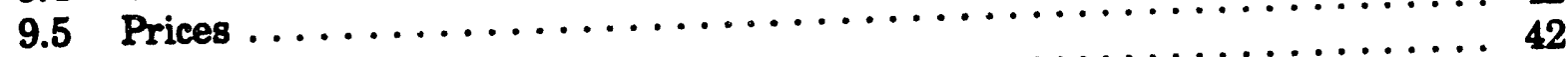

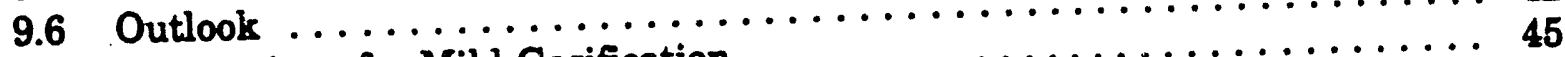

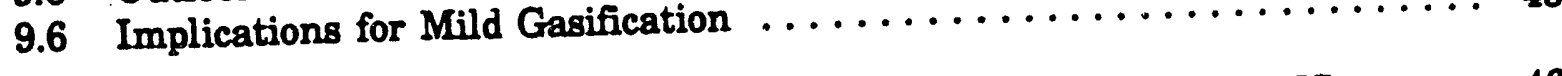

10.0 MIID GASTIFICATION CHAR FOR CONTROL OF TOXIC EMISSIONS . . . . 46

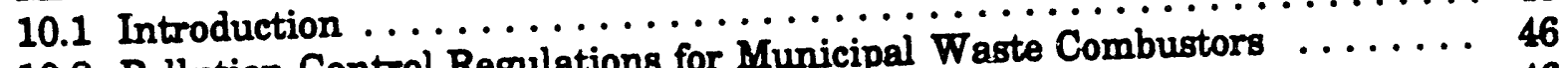

10.2 Pollution Control Regulations for Municipal Waste Combustors . . . 46

10.2.1 New Rules Issued by EPA . . . . . . . . . . . . . . . . . . . . . . . 4.47

10.2.2 Regulation of MWC Emissions by Local Jurisdictions . . . . . . . . . 47

10.3 The State of the Art for MWC Emission Control $\ldots \ldots \ldots \ldots \ldots \ldots \ldots \ldots \ldots$

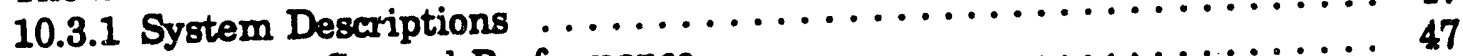

10.3.2 Pollution Control Performance $\ldots \ldots \ldots \ldots \ldots \ldots \ldots \ldots \ldots \ldots \ldots \ldots \ldots \ldots$

10.4 The Activated Char Filtration System $\ldots \ldots \ldots \ldots \ldots \ldots \ldots \ldots \ldots \ldots \ldots$

10.4.1 System Descriptions ......................... 50

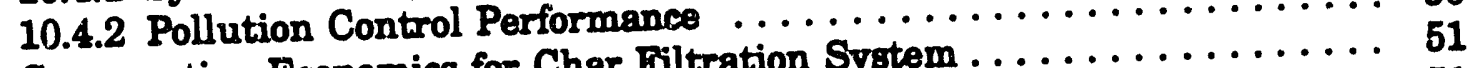

10.5 Comparative Economics for Char Filtration System ............... 51

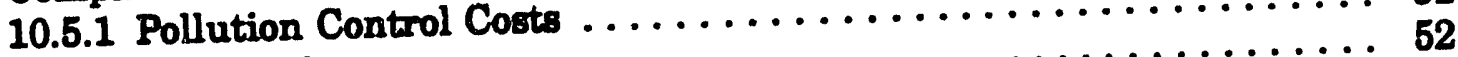

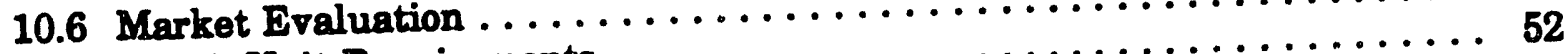

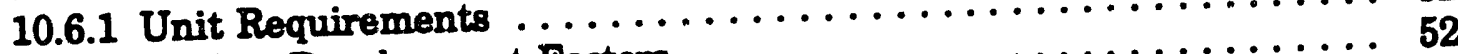

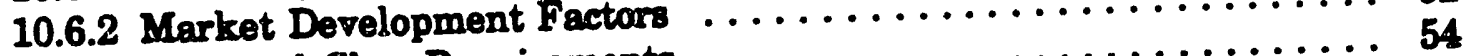

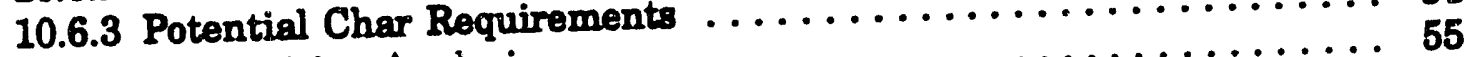

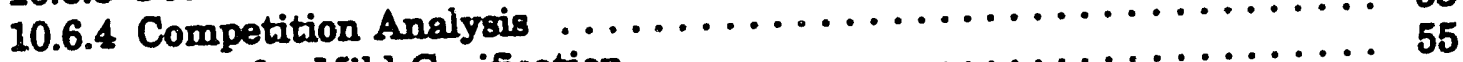

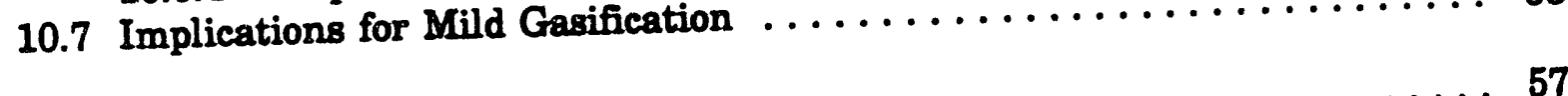

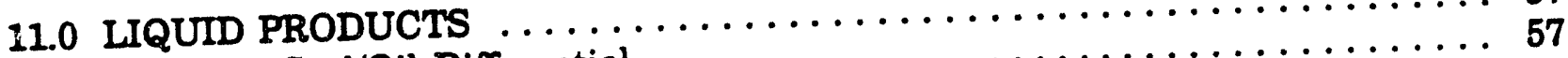

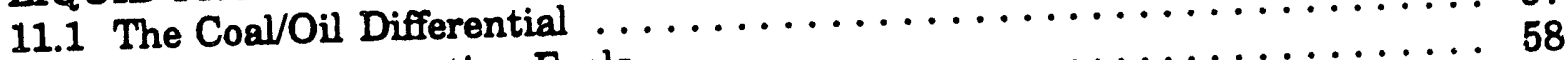

11.2 Liquid Transportation Fuels $\ldots \ldots \ldots \ldots \ldots \ldots \ldots \ldots \ldots \ldots \ldots \ldots \ldots \ldots$

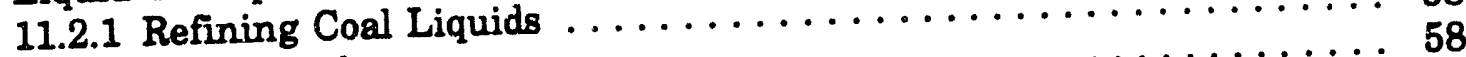

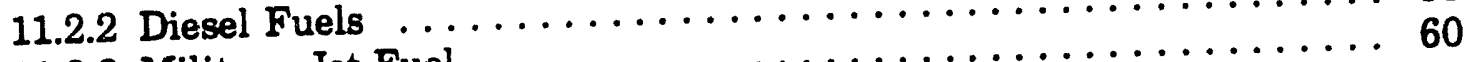

11.2.3 Military Jet Fuel . 


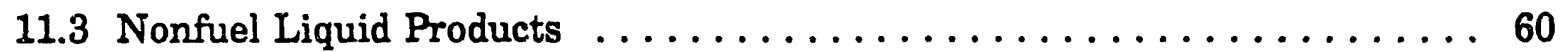

11.3.1 Benzene, BTX . . . . . . . . . . . . . . . . . 60

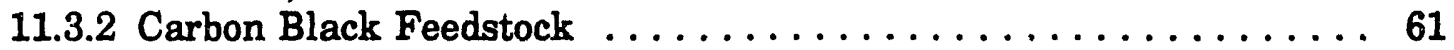

11.3.3 Creosote ........................... 61

11.3.4 Cresols and Cresylic Acid ................... 63

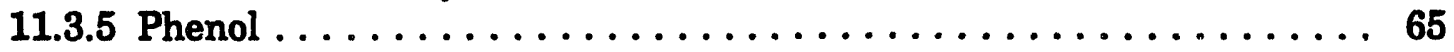

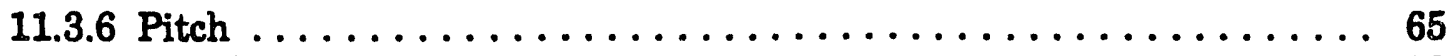

11.3.7 Tar Crude ........................... 68

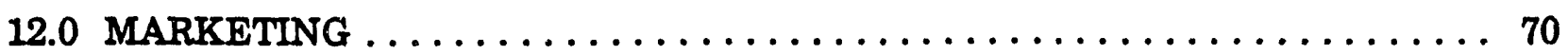

13.0 PROJECT FINANCIAL ANALYSIS $\ldots \ldots \ldots \ldots \ldots \ldots \ldots \ldots \ldots \ldots$

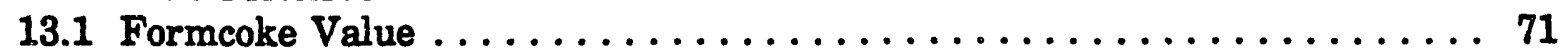

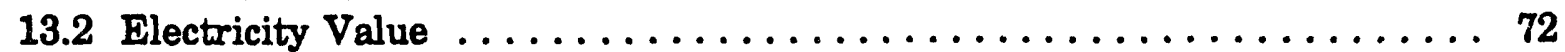

13.3 Product Rates ............................. 72

13.3.1 Formcoke .......................... 72

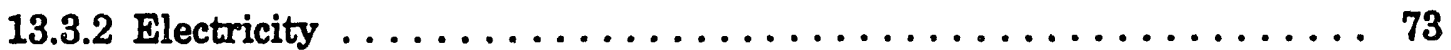

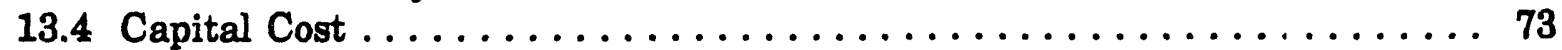

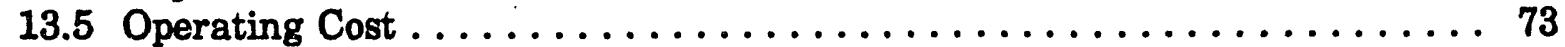

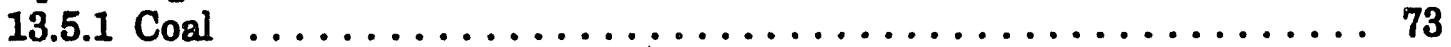

13.5.2 Limestone ............................... 73

13.5.3 Disposal Costs . ........................ 74

13.5.4 Water ................................. 74

13.5.5 Chemicals .......................... 74

13.5.6 Supplies and Maintenance $\ldots \ldots \ldots \ldots \ldots \ldots \ldots \ldots \ldots \ldots \ldots 74$

13.5.7 Labor . . . . . . . . . . . . . . . . . . . . 74

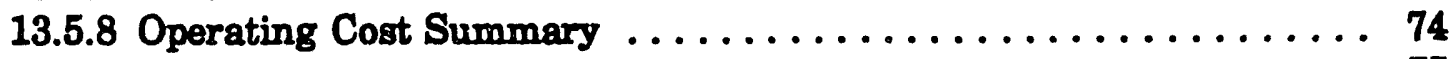

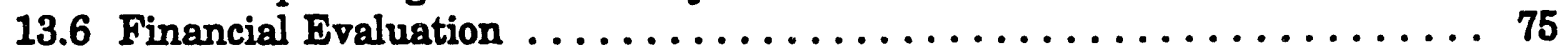

13.6.1 Evaluation Parameters ..................... 75

13.6.2 Base-Case Results ........................ 75

13.6.3 Sensitivity to Electricity Prices ................. 77

13.6.4 Sensitivity to Coal Cost . . . . . . . . . . . . . . . . 77

13.6.5 Probability Distribution on Cost Sensitivity ............ 79

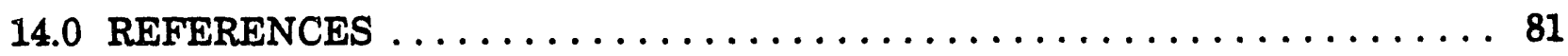




\section{LIST OF FIGURES}

Figure

Page

1 Mild gasification process integration $\ldots \ldots \ldots \ldots \ldots \ldots \ldots \ldots$

2 CAAA coke-oven enactment schedule $\ldots \ldots \ldots \ldots \ldots \ldots \ldots \ldots$

$3 \quad$ Coke-oven locations $\ldots \ldots \ldots \ldots \ldots \ldots \ldots \ldots \ldots \ldots \ldots \ldots \ldots$

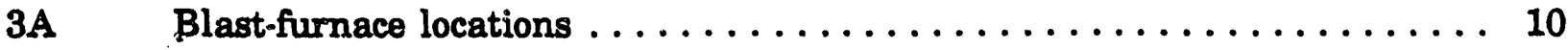

4 Cokemaking capacity assuming 40-year retirement age $\ldots \ldots \ldots \ldots \ldots 14$

5 Estimation of new cokemaking capacity needed $\ldots \ldots \ldots \ldots \ldots \ldots \ldots$

6 Total steel production and consumption in the United States . . . . . . . 19

7 Share of steel production by technology $\ldots \ldots \ldots \ldots \ldots \ldots \ldots \ldots$

8 Coke production in the United States $\ldots \ldots \ldots \ldots \ldots \ldots \ldots \ldots$

$9 \quad$ World direct-reduced iron production $\ldots \ldots \ldots \ldots \ldots \ldots \ldots \ldots \ldots$

$10 \quad$ United States raw stoel production $\ldots \ldots \ldots \ldots \ldots \ldots \ldots \ldots \ldots$

11 Steel industry net income $\ldots \ldots \ldots \ldots \ldots \ldots \ldots \ldots \ldots \ldots \ldots$

12 United States production of activated carbon products . . . . . . . . 39

13 Activated carbon producers $\ldots \ldots \ldots \ldots \ldots \ldots \ldots \ldots \ldots \ldots \ldots \ldots$

14 Mercury removal by emission control devices $\ldots \ldots \ldots \ldots \ldots \ldots \ldots \ldots$

15 Stadtwerke Düsseldorf activatod carbon scrubber $\ldots \ldots \ldots \ldots \ldots \ldots \ldots . . .49$

16 Estimated concentrations of pollutants in flue gas for different control technologies ........................ 51

17 Projected technologies to be used in MWC plants subject to NSPS

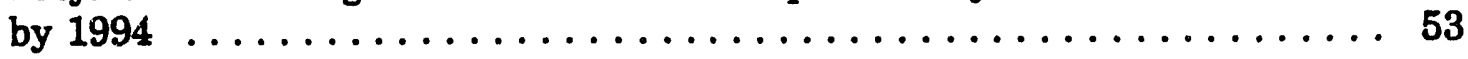

18 Solid waste flow projections $\ldots \ldots \ldots \ldots \ldots \ldots \ldots \ldots \ldots \ldots \ldots \ldots$

$19 \quad \mathrm{Coal} /$ crude oil discount factor $\ldots \ldots \ldots \ldots \ldots \ldots \ldots \ldots \ldots \ldots$

$20 \quad$ Locomotive diesel fuel consumption $\ldots \ldots \ldots \ldots \ldots \ldots \ldots \ldots$

$21 \quad$ Locomotive diestil fuel cost $\ldots \ldots \ldots \ldots \ldots \ldots \ldots \ldots \ldots$ 


\section{LIST OF FIGURES (continued)}

Figure

Historical benzene prices DCFROR as a function of coal costs and formcoke prices $\ldots \ldots \ldots \ldots \ldots 78$ 


\section{LIST OF TABLES}

Table

Page

1 CAAA Coke Oven Emission Limits $\ldots \ldots \ldots \ldots \ldots \ldots \ldots \ldots \ldots \ldots \ldots \ldots$

2 Coke Producers and Blast Furnaces in the United States, $1991 \ldots \ldots$

$3 \quad$ Age and Capacity of Steelmaking Coke Batteries in $1991 \ldots \ldots \ldots$

$4 \quad$ Age and Capacity of Steelmaking Coke Batteries after 1993-95 . . . . . . 15

$5 \quad$ Age and Estimated Capacity of Steelmaking Coke Batteries after 1998 . . 16

6 Unit Consumption of Coke in the Production of Iron and Steel . . . . . . 20

7 Estimated Total Coke Demand for 60 Million Tons of Raw Steel from BOFs . ............................ 21

8 Probable Cost of Replacement of the Coke Shortfall .............. 22

9 Coke Plant Products $\ldots \ldots \ldots \ldots \ldots \ldots \ldots \ldots \ldots \ldots \ldots \ldots \ldots \ldots$

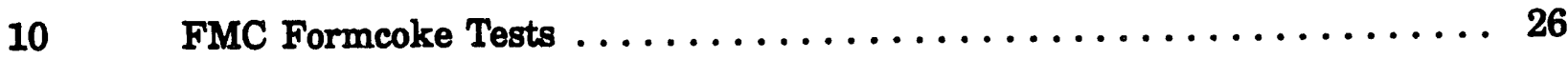

11 Advanced Formcoke Processes $\ldots \ldots \ldots \ldots \ldots \ldots \ldots \ldots \ldots$

12 Steel Mill Products Trends and Projections $\ldots \ldots \ldots \ldots \ldots \ldots \ldots \ldots$

13 Production of Activated Carbon by Type $\ldots \ldots \ldots \ldots \ldots \ldots \ldots$

$14 \quad$ U.S. Imports of Activated Carbon $\ldots \ldots \ldots \ldots \ldots \ldots \ldots \ldots$

$15 \quad$ U.S. Exports of Activated Carbon $\ldots \ldots \ldots \ldots \ldots \ldots \ldots \ldots \ldots$

16 Average Values of Shipments of Activated Carbon $\ldots \ldots \ldots \ldots \ldots . \ldots 4$

17 Operating Cost Summary $\ldots \ldots \ldots \ldots \ldots \ldots \ldots \ldots \ldots \ldots \ldots \ldots \ldots \ldots$

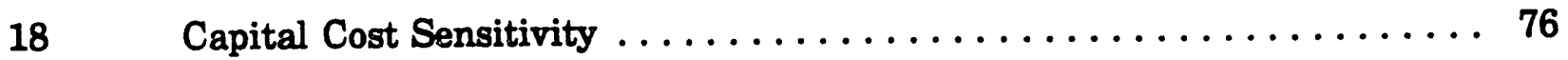

$19 \quad$ Electricity Price Sensitivity $\ldots \ldots \ldots \ldots \ldots \ldots \ldots \ldots \ldots \ldots \ldots$

$20 \quad$ Coal Cost Sensitivity $\ldots \ldots \ldots \ldots \ldots \ldots \ldots \ldots \ldots \ldots \ldots \ldots \ldots$

21 Probability Distribution on DCFROR as a Function of Capital Cost and Coke Prices ......................... 80 


\section{ADDENDUM TO \\ INDUSTRIAL MARKET ASSESSMENT OF THE PRODUCTS OF MILD GASIFICATION}

\subsection{INTRODUCTION}

The objective of this report is to review and update the 1988 report by J.E. Sinor Consultants Inc., "Industrial Market Assessment of the Products of Mild Gasification," and to more fully present market opportunities for two char-based products from the mild gasification process (MGP): formcoke for the iron and steel industry, and activated carbon for wastewater cleanup and flue gas scrubbing. Please refer to the original report for additional details.

In the past, coal conversion projects have usually been justified on the basis of gas and liquids produced, and the value of the residual char was limited to its fuel value. Some projects had limited success until gas and oil competition overwhelmed them. The strategy adopted for this assessment is to seek first a premium value for the char in a market that has advantages over gas and oil, and then to find the highest values possible for gases, liquids, and tars, either on-site or sold into existing markets.

During the intervening years since the 1988 report, there have been many changes in the national economy, industrial production, international competition, and environmental regulations. The Clean Air Act Amendments of 1990 (CAAA) will have a large impact on industry. There is considerable uncertainty about how the Act will be implemented, but it specifically addresses coke-oven batteries. This may encourage industry to consider formcoke produced via mild gasification as a low-pollution substitute for conventional coke. The chemistry and technology of coke in making steel were reviewed in the 1988 market assessment and will not be repeated here. The CAAA require additional pollution control measures for most industrial facilities, but this creates new opportunities for the mild gasification process. 


\subsection{MARKET OPPORTUNITIES FOR MILD GASIFICATION CHAR}

\subsection{Impact of CAAA on Coke Ovens}

The Act specifically addresses coke-oven emissions and proposes that emission limits be promulgated by December 31, 1992. The Environmental Protection Agency (EPA) has been negotiating with industry representatives and will hold public hearings. The production of formcoke from MGP char was discussed in the original market assessment. Development of the formcoke market (substitution of formcoke for oven coke) will depend on the coke and steel industry's reaction to the regulations and how they are enforced.

There is considerable speculation about the impact of the CAAA on the industry and on older coke ovens in particular. Industry estimates suggest that up to $40 \%$ of the older coke ovens may be forced to close due to the cost of adding more pollution controls. A report (1) by Research Triangle Institute states that no coke ovens will close solely because of the CAAA, but concludes that some older ovens will close simply because they will become too costly to operate.

Because of these closures, industry and government estimates of coke supply shortfall range from 2 to 6 million tons per year for the period 1993 to 2003. The U.S. Bureau of Mines (2) has presented the higher number, based on an analysis of the iron and steel industry.

\subsection{Impact of CAAA on Electric Utilities}

Another requirement of the CAAA is a reduction of $\mathrm{SO}_{2}$ and $\mathrm{NO}_{2}$ emissions from coal-fired electric utilities. Again, this creates a potential opportunity, this time to clean flue gases using an activated carbon scrubbing system. The activated carbon may be produced via mild gasification. Several German and Japanese companies are working on such a process to compete with selective catalytic reduction.

Activated carbon scrubbers may be useful in meeting future requirements to remove air toxics. Such regulations have not yet been promulgated for electric utilities.

\subsection{Impact of CAAA on Municipal Waste Combustors}

The CAAA of 1990 require that EPA promulgate limits on emissions of mercury from municipal waste combustors. Mild gasification char from lignite, and possibly from other types of coal, can be used as an adsorbent for mercury in stack gases from municipal waste combustors. Until the final regulations are issued, it is not known whether control systems will be required.

\subsection{Market for MGP Activated Carbon}

Investment risk in an MGP project can be reduced by expanding the number of marketable products. Production of activated carbon presents another attractive opportunity because the same facility, with the addition of a steam activation system, can then produce the activated carbon as well as formcoke (Figure 1). Two separate and noncompetitive product lines increase project viability by complementing the immediate but steady or declining formcoke market with the growing activated carbon market. 
MGP char can be activated with steam or chemicals to produce activated carbon to meet this new need as well as existing markets. Existing markets include water treatment, which is a large and growing market. A plant designed to produce formcoke could split the char product into both formcoke and activated carbon process streams. Current consumption of activated carbon is limited by product cost, nominally at about $\$ 1.00$ per pound, and also by limited enforcement of the Clean Water Act. Anticipation of new business as a result of passage of the Clean Water Act in 1987 encouraged manufacturers to increase production capacity for demand which did not materialize. Production capacity was then scaled back. Recently increased demand has again encouraged manufacturers to increase capacity.

The productive capacity of MGP plants will be large, requiring one to look for larger markets, which will be commodity-type markets. Such markets require a product that can compete on price and meet existing product specifications. Energy and processing accounts for about 80 percent of activated carbon cost, and material only 20 percent. The first target market is activated carbon used in wastewater treatment.

If MGP char could be steam activated as it exits the gasifier, the energy savings would offer a competitive price advantage over conventional carbon production. If the price is low enough, it may encourage wider applications of activated carbon and increase market size substantially.

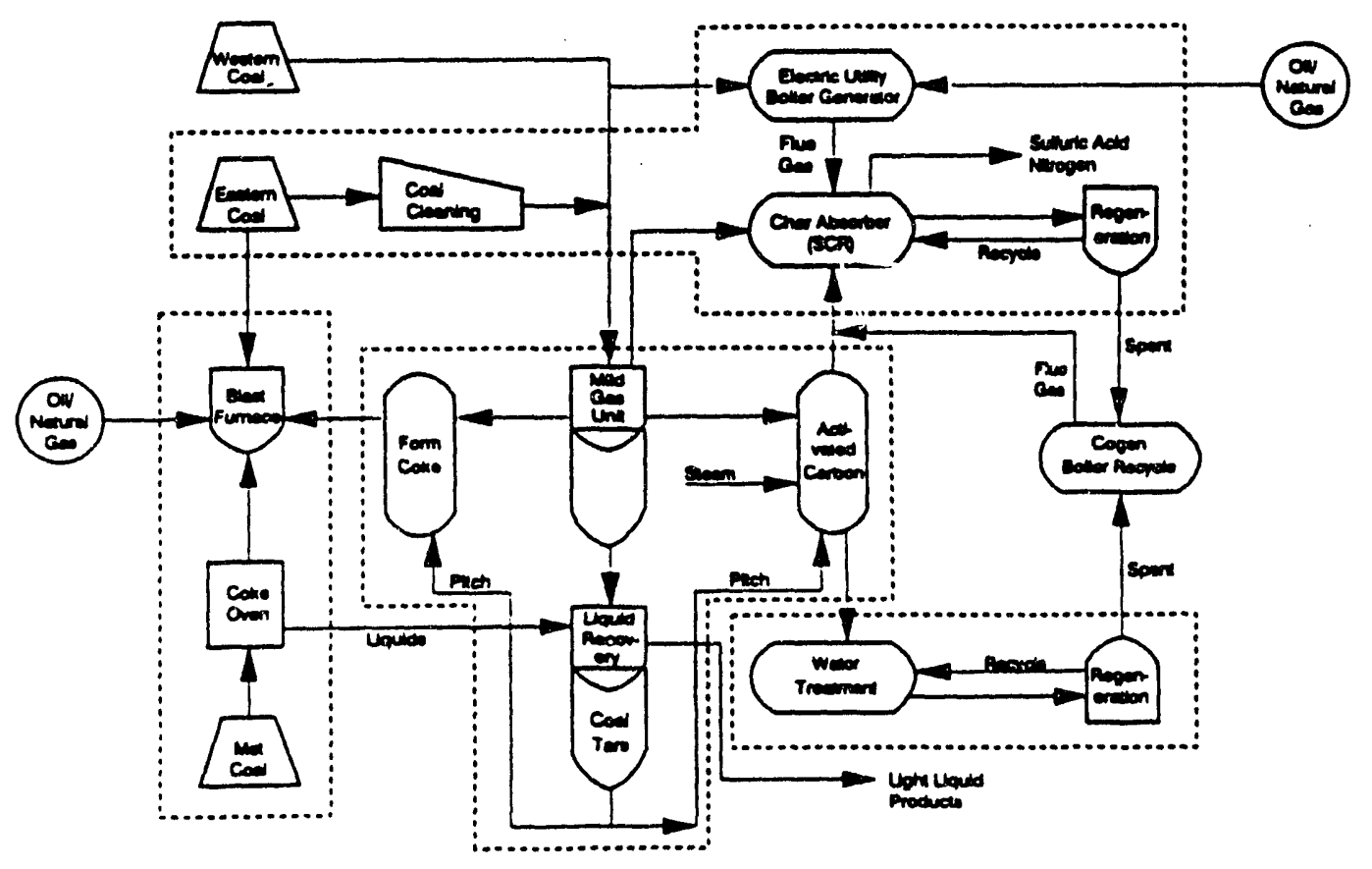

Figure 1. Mild gasification process integration. 
On-site regeneration of activated carbon is limited by the properties of the carbon and the application. If on-site regeneration is not possible, then the carbon must be replaced or sent to off-site regeneration. An alternative procedure includes recovering the fuel value of the spent carbon in a boiler rather than relying on off-site regeneration (Figure 1). 


\subsection{THE CLEAN AIR ACT AMENDMENTS OF 1990 AS THEY AFFECT THE COKE AND STEEL INDUSTRY}

The Act has seven titles of which only the first is of major technological importance to the steel industry, with four subsequent titles having a lesser effect. The five titles of interest are:

- Air toxics.

- Acid rain.

- Nonattainment areas.

- Permits.

- Enforcement.

The air toxics title singles out the coke industry in great detail. Basically, it deals with existing coke batteries, but includes new, replacement batteries and rebuilt, upgraded ones.

The limits on emission of pollutants are expressed as maximum percentages of visually leaking oven openings. There is no differentiation between heavy and light leaks.

The Act specifies three groups of controls:

- Maximum Achievable Control Technology (MACT)

- Lowest Achievable Emission Rate (LAER)

- An "ample margin of health safety," expressed as residual health risk-based standard $(R)$

It also mentions "work practice standards," especially the use of sodium silicate for sealing doors.

The Act gives coke managers two options to achieve the now pollution limits: the MACT option (Option I in Figure 2), and the "extension track" option (Option II in Figure 2). The emission limits which take effect at the dates shown in Figure 2 are listed in Table 1.

\subsection{The MACT Option}

Under Option I, the standards required, including a "work practice" standard if deemed desirable by the EPA, are to be established by December 31, 1992, and compliance secured by December 31, 1995. The MACT standards cannot be more lenient than:

- 8\% leaking doors maximum.

- $1 \%$ leaking lids.

- $5 \%$ leaking offtakes.

- 16 seconds of pollution emissions per charge. 


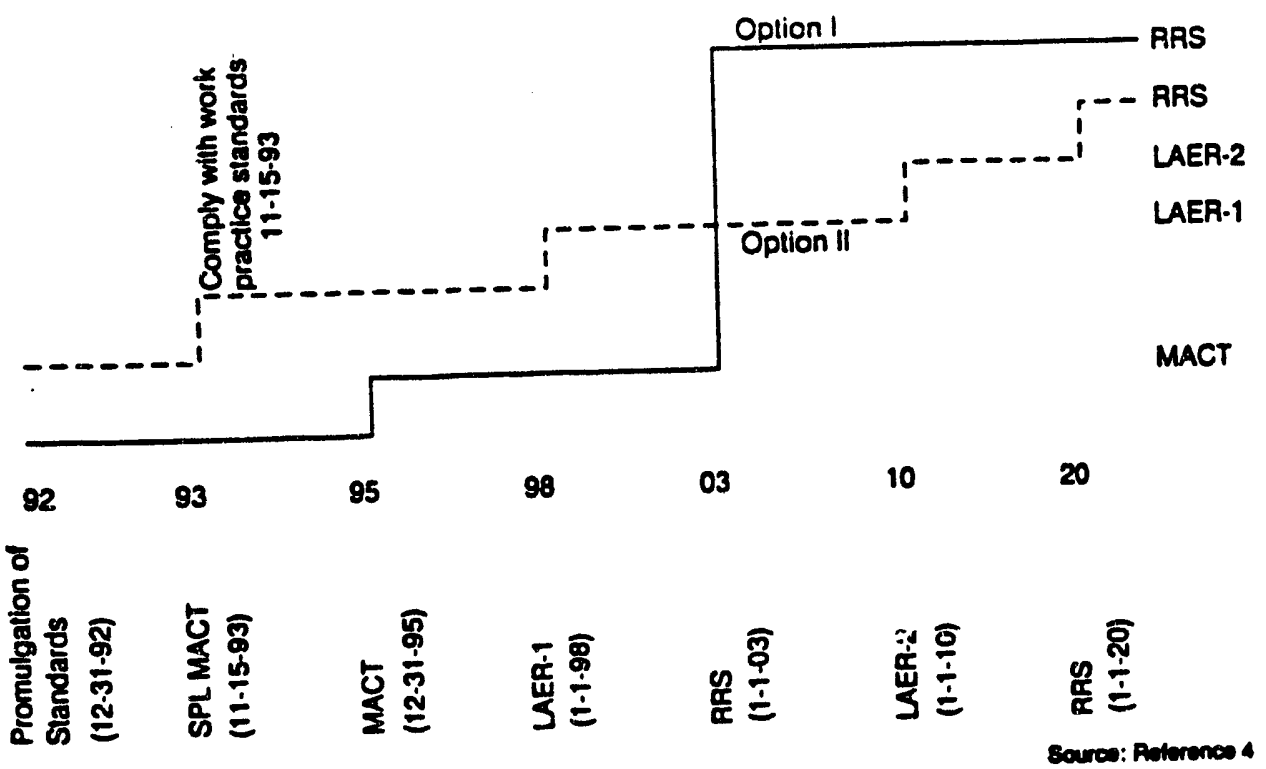

Figure 2. CAAA coke-oven enactment schedule.

TABLE 1

CAAA Coke (Vven Emission Limits

\begin{tabular}{|c|c|c|c|c|c|c|}
\hline & \multirow[b]{2}{*}{$\begin{array}{l}\text { Charging } \\
\text { Time (sec) }\end{array}$} & \multicolumn{3}{|c|}{ Leats, \% } & \multirow[b]{2}{*}{ Effective } & \multirow[b]{2}{*}{ Comment } \\
\hline & & Doors & Lids & Ofitakes & & \\
\hline $\begin{array}{l}\text { NESHAP } \\
\text { MACT } \\
\text { LAER-1 } \\
\text { LAER-2 }\end{array}$ & $\begin{array}{l}16 \\
16 \\
16 \\
16 \\
16 \\
16\end{array}$ & $\begin{array}{r}10 \\
8 \\
3 \\
5 \\
3 \\
5\end{array}$ & $\begin{array}{l}3 \\
1 \\
1 \\
1 \\
1 \\
1\end{array}$ & $\begin{array}{l}6 \\
5 \\
5 \\
5 \\
4 \\
4\end{array}$ & $\begin{array}{c}1987 \\
1993-95 \\
1998 \\
1998 \\
2010 \\
2010 \\
2003 \& 2020\end{array}$ & $\begin{array}{l}\text { Not Promulgated } \\
\text { For < } 6 \text { meter batteries } \\
6 \text { meter batteries } \\
<6 \text { meter batteries } \\
6 \text { meter batteries }\end{array}$ \\
\hline RRS & \multicolumn{6}{|c|}{ Residual risk standards to be determined } \\
\hline
\end{tabular}


Industry estimates indicate that the above will result in a $66 \%$ reduction of emissions in comparison with the performance mandated in 1970.

The standards are to be reviewed every 7 years by the EPA to determine whether increased stringency is warranted. The performance of the best $12 \%$ of batteries may be established as a standard after 1995.

The residual health risk standard is to be met by January 1, 2003. This will necessitate establishing maximum lifetime risk levels of 1 in 10,000 in the close vicinity of source areas and 1 in 1,000,000 in the surrounding areas in which post-MACT residual risks will have to be assessed. The compliance with residual risk (that remains after MACT) must be achieved by 2003 or the facility will be shut down. Doubts are being raised as to whether it is technically feasible to achieve the required risk levels.

Option I is likely to be elected only by companies planning to close their coke plants by 2003 or earlier.

\subsection{The "Extension Track" Option}

Under Option II, compliance with the above-mentioned work practices is to be achieved along with a special MACT by November 15, 1993. LAER-1 standards are to be published by December 31, 1992 (together with the MACT standards), and cannot be less stringent than $3 \%$ leaking doors (5\% for tall, more than 5-meter batteries) with some exclusion for just-charged doors, and the same other standards as in the MACT standard.

The visual estimate of leakages may be replaced by some mass emissions equivalent. Compliance must be achieved by 1998.

A new LAER standard (LAER-2) is to be proclaimed by January 1, 1998. If the EPA does not establish one, the new standard will be:

- $3 \%$ leaking doors (5\% for tall ovens) with no charging exclusion.

- 1\% leaking lids.

- $4 \%$ leaking offtakes.

- 16 seconds of pollution emissions.

Reduction of emissions from the 1970 standard is estimated to be $86 \%$.

Companies must comply with this standerd by January 1, 2010, but the LAER must be reviewed, reapproved, or tightened by January 1, 2007. 2020.

Finally, the undefined residual health risk standard must be met by January 1 ,

\subsection{Other Considerations}

Probably in recognition of the nonexistence or vagueness of the standards, the Act orders a number of supporting studies. The EPA is to study, jointly with the Department of Energy, the entire problem of controlling coke-oven emissions; $\$ 30$ million is envisaged for this 6.year study. 
The EPA itself is to evaluate the Jewell design of the Thompson nonrecovery, nonpolluting battery and other, unspecified technologies. It is to develop a better, visual standard of coke-oven leakage and a nonsubjective, mass emission standard as well, to quantify the amount of pollution. At least 50\% of the costs of these projects is to come from nonfederal sources. The Act does not specify from where or how these contributions are to be obtained.

The presently undefined "residual risk health standard" is to be developed by a joint study involving the Surgeon General and the EPA; the National Academy of Sciences is to work out the risk assessment methodology.

Title II, which deals with "acid rain," has little application to coke. It may, however, strongly affect the nonintegrated steel producers that use electric arc furnaces.

Title.III deals with the 80 to 100 nonattainment areas. As far as coke plants are concerned, this is a relatively minor problem, but the plants may be forced to install additional pollution controls as a result of excessive general pollution at their areas. Bans on further construction are also possible.

Title IV, "Permits," transfers the issuance of detailed operating permits to the states. From 1996 on, the permits will be issued for a maximum period of 5 years.

The "Enforcement" title specifies civil and criminal penalties for noncompliance, including the crime of false record-keeping.

Some possible consequences of the Act have been pointed out by Peters (2):

- By specifying the existence, but not the severity of leaks, the Act may actually result in increased pollution: a manager, staying within the permitted percentages, may disregard a large leak in favor of an easier-to-seal light leak.

- The compression of the standards-setting process into only 2 years may not allow enough time for proper development of standards by cooperation of the industry with the EPA-risking a spate of court actions.

- The timing of the compliance dates, coupled with the uncertainty caused by periodic reviews of the rules by the EPA and the periodic reissuance of permits by the states, and perhaps even localities, could present complex difficulties for the industry in attempting to comply with the Act. Planning of a new coke battery requires about 5 years from inception to start-up.

- The Act also does not address directly the complex question of air sampling and chemical determination of mass emission of contaminants implied in the future limits based on health risks. 


\subsection{STRUCTURE OF THE COKE INDUSTRY}

The great majority of coke plants (Figure 3) belong to steel companies. These plants are at the ironmaking and steelmaking sites (Figure 3A). The output of these captive batteries is often supplemented by imported coke or coke bought from independent producers. A complete listing of coke producers and blast-furnace operators is given in Table 2.

The age of the industry is considerable. Nearly $30 \%$ of all batteries are already more than 30 years old. Data from the American Iron and Steel Institute (AISI), updated for one closure in the first quarter of 1991, are shown in Table 3. Assuming a coke yield of $65 \%$, about 39 million tons of coal is required at full capacity utilization.

The average age of installations is close to 22 years, while 30 to 40 years may be regarded as the limit of productive coke battery life. If all existing batteries can be extended to a 40-year lifetime, and no new ones are built, the curve of future cokemaking capacity would appear as in Figure 4.

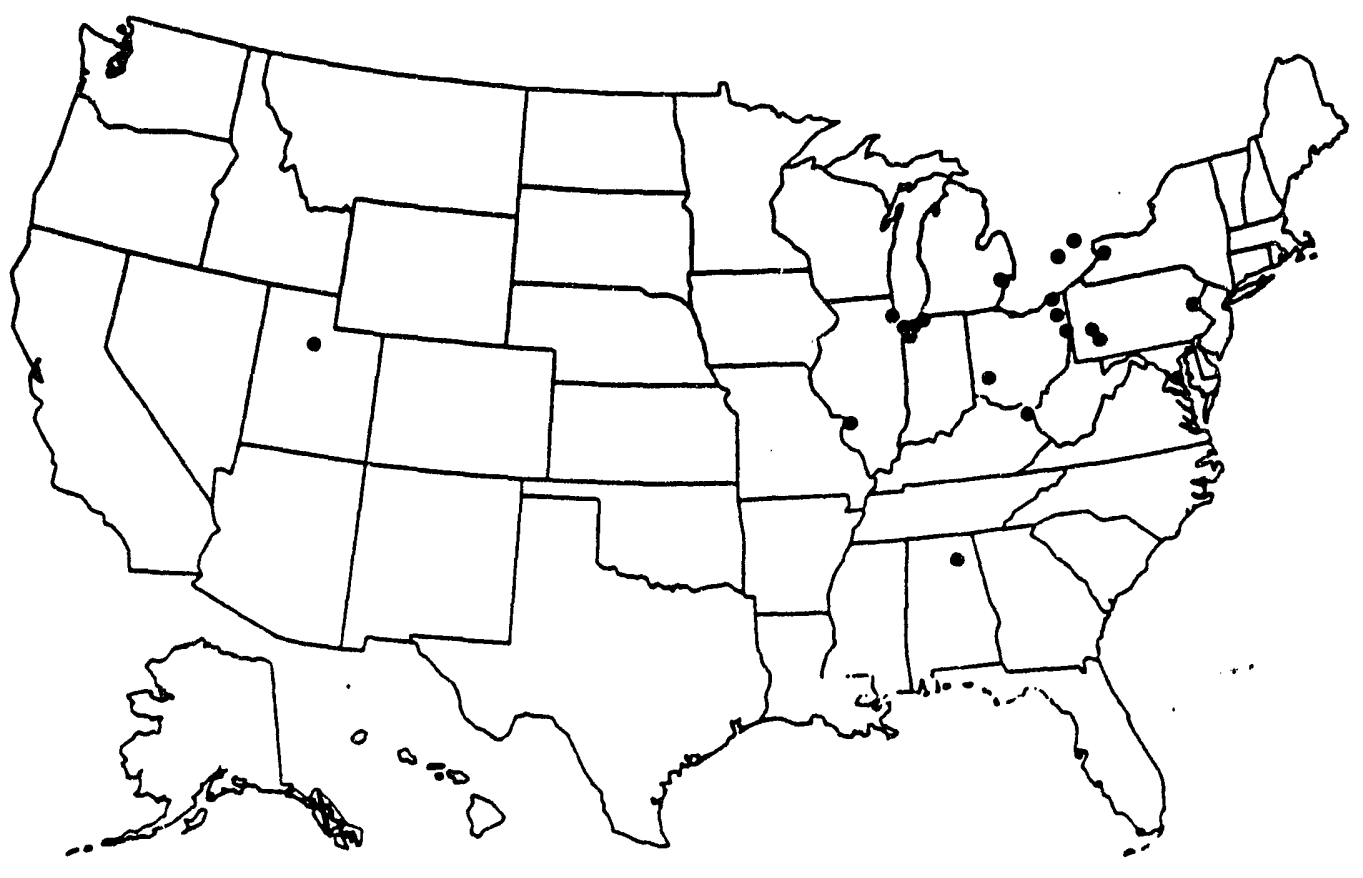

Figure 3. Coke-oven locations. 


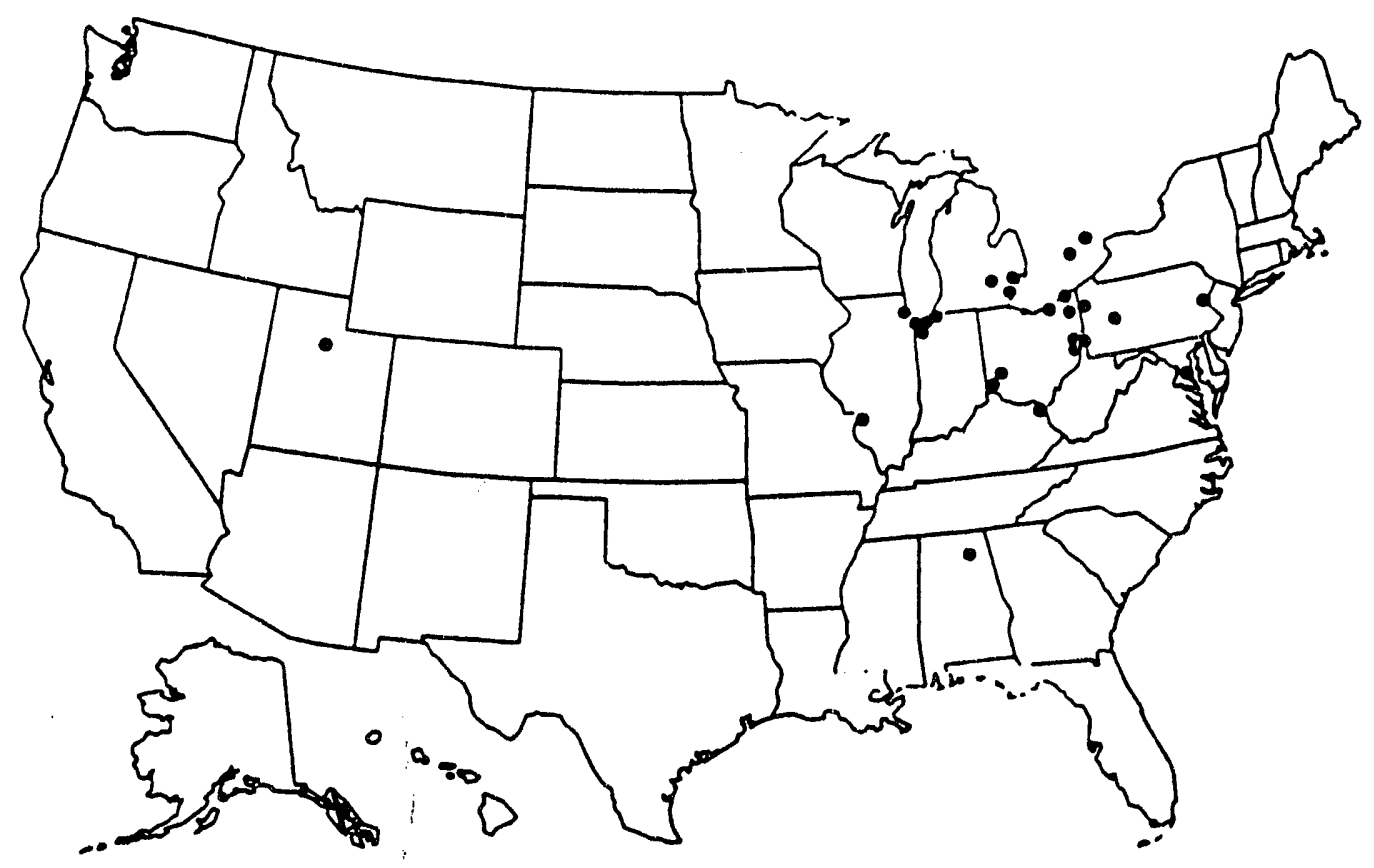

Figure 3A. Elast-furnace locations.

TABLE 2

Coke Producers and Blast Furnaces in the United States, 1991

Plant Name

Battery Coke Capacity

City, State (1000 Mg)

\section{Foundry}

ABC Coke

Tarrant, AL

353

113

117

Citizens Gas

Indianapolis, IN

79

93

305

Detroit Coke

Detroit, MII

617

Empire Coke

Holt, AL

54

Erie Coke

Erie, PA

107

Koppers Industries

Woodward, AL

82

125

55

97

128

161

252

continued... 
TABLE 2 (continued)

Coke Producers and Blast Furnaces in the United States, 1991

\begin{tabular}{|c|c|c|}
\hline Plant Name & City, State & $\begin{array}{c}\text { Battery Coke Capacity } \\
(1000 \mathrm{Mg})\end{array}$ \\
\hline Toledo Coke & Toledo, OH & 157 \\
\hline Tonawanda & Tonawanda, NY & 299 \\
\hline \multicolumn{3}{|l|}{ Furnace } \\
\hline Acme Steel & Chicago, IL & $\begin{array}{l}291 \\
291\end{array}$ \\
\hline Armco, Inc. & Middletown, $\mathrm{OH}$ & $\begin{array}{l}343 \\
544 \\
544\end{array}$ \\
\hline Armco, Inc. & Ashland, KY & $\begin{array}{l}430 \\
631\end{array}$ \\
\hline Bethlehem Steel & Bethlehem, PA & $\begin{array}{l}364 \\
364 \\
808\end{array}$ \\
\hline Bethlehem Steel & Burns Harbor, IN & $\begin{array}{l}880 \\
880\end{array}$ \\
\hline Bethlehem Steel & Lackawarnna, NY & $\begin{array}{l}397 \\
397\end{array}$ \\
\hline Bethiehem Steel & Sparrows Point, MD & $\begin{array}{l}220 \\
220 \\
795\end{array}$ \\
\hline Geneva Steel & Provo, UT & $\begin{array}{l}290 \\
290 \\
290 \\
290\end{array}$ \\
\hline Gulf States Steel & Gadsden, AL & $\begin{array}{l}379 \\
379\end{array}$ \\
\hline Inland Steel & East Chicago, IN & $\begin{array}{r}226 \\
343 \\
343 \\
381 \\
547 \\
1154\end{array}$ \\
\hline
\end{tabular}


TABLE 2 (continued)

Coke Producers and Blast Furnaces in the United States, 1991

\begin{tabular}{|c|c|c|}
\hline Plant Name & City, State & $\begin{array}{l}\text { Battery Coke Capacity } \\
(1000 \mathrm{Mg})\end{array}$ \\
\hline LTV Steel & Cleveland, $\mathrm{OH}$ & $\begin{array}{l}274 \\
274 \\
274 \\
366 \\
366\end{array}$ \\
\hline LTV Steel & Pittsburgh, PA & $\begin{array}{l}340 \\
340 \\
340\end{array}$ \\
\hline LTV Steel & Pittsburgh, PA & $\begin{array}{l}340 \\
432\end{array}$ \\
\hline LTV Steel & South Chicago, II & 596 \\
\hline LTV Steel & Warren, OH & 540 \\
\hline National Steel & Ecorse, MI & 345 \\
\hline National Steel & Granite City, $\pi$ & $\begin{array}{l}314 \\
314\end{array}$ \\
\hline New Boston & Portsmouth, OH & 364 \\
\hline Sharon Steel & Monessen, PA & $\begin{array}{l}100 \\
195\end{array}$ \\
\hline Shenango & Pittsburgh, PA & $\begin{array}{l}199 \\
322\end{array}$ \\
\hline Sloss Industries & Birmingham, AL & $\begin{array}{l}100 \\
100 \\
197\end{array}$ \\
\hline USX & Clairton, PA & $\begin{array}{l}285 \\
285 \\
285 \\
285 \\
285 \\
285 \\
299 \\
299 \\
299 \\
500 \\
500 \\
838\end{array}$ \\
\hline
\end{tabular}


TABLE 2 (continued)

Coke Producers and Blast Furnaces in the United States, 1991

\begin{tabular}{|c|c|c|}
\hline Plant Name & City, State & $\begin{array}{l}\text { Battery Coke Capacity } \\
(1000 \mathrm{Mg})\end{array}$ \\
\hline USX & Gary, IN & $\begin{array}{l}265 \\
265 \\
750 \\
750\end{array}$ \\
\hline Wheeling-Pittsburgh & East Steubenville, WV & $\begin{array}{l}199 \\
199 \\
215 \\
896\end{array}$ \\
\hline $\begin{array}{l}\text { Foundry } \\
\text { Furnace }\end{array}$ & & $\begin{array}{r}3,194 \\
28,327\end{array}$ \\
\hline Total & & 31,521 \\
\hline
\end{tabular}

Source: Research Triangle Institute. Industry Profile: Current Status in 1991.

Additional Blast Furnaces

McLouth

Rouge Steel

Trenton, MI

Weirton Steel

Dearborn, MII

Weirton, WV

\section{TABLE 3}

Age and Capacity of Steelmaking Coke Batteries in 1991

\begin{tabular}{cccc}
\hline Age, Years & $\begin{array}{c}\text { Number of } \\
\text { Batteries }\end{array}$ & $\begin{array}{c}\text { Capacity, } \\
\text { (Million Tons) }\end{array}$ & $\%$ \\
\hline 5 or less & 2 & 0.6 & 2.4 \\
6 to 10 & 9 & 5.0 & 19.9 \\
11 to 15 & 14 & 8.5 & 33.9 \\
16 to 20 & 3 & 1.6 & 6.4 \\
21 to 25 & 2 & 0.5 & 2.0 \\
26 to 30 & 4 & 1.6 & 6.4 \\
31 to 35 & 12 & 3.1 & 12.3 \\
More than 35 & 19 & 4.2 & 100.0 \\
Total & 65 & 25.1 & \\
Average capacity per battery & & 0.39 million tons \\
Average capacity per battery & & & \\
built after 1970 & & 0.51 million tons &
\end{tabular}




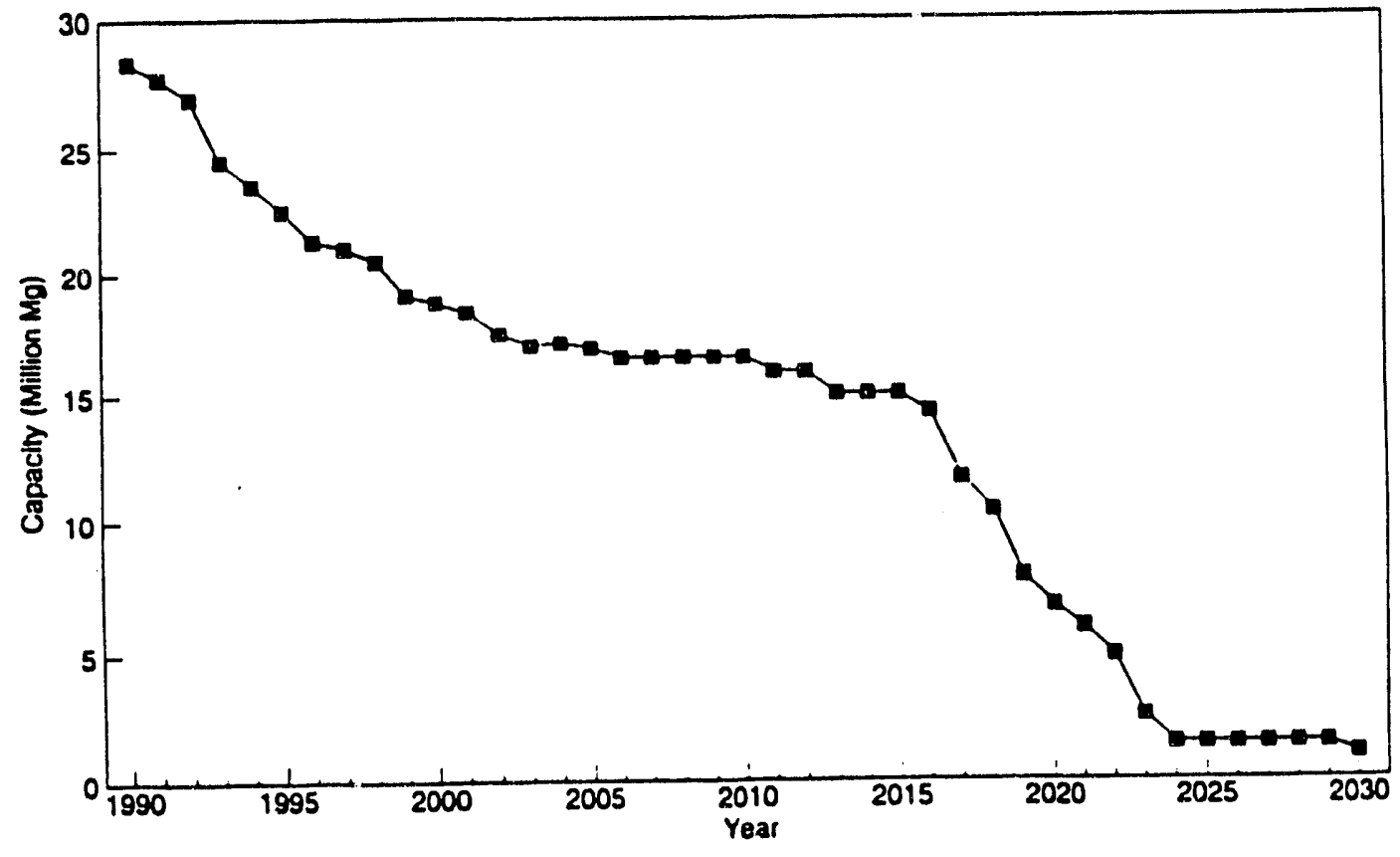

Source: J G. H. and Associstes

Figure 4. Cokemaking capacity assuming 40-year retirement age.

\subsection{The Merchant Coke Industry}

The part of the industry that is not owned by steel companies, usually called independent or merchant coke producers, consists of 13 batteries with a combined capacity of approximately 4 million tons per year. About 1.5 to 2 million tons is consumed by iron foundries, and the balance (made to blast-furnace standards) is sold to blast-furnace operators. Foundry coke is not suitable for blast furnaces.

Most of these batteries are old. However, age is not a strong criterion of a foundry coke battery's usefulness because the operating conditions of the ovens are much more lenient than those of the steel mill coke plants.

The coking temperature is lower, the kind of coal is less destructive to oven walls, and the ovens are lower, usually not more than 12 feet tall, consequently with much smaller door distortion, etc. Thus meeting a criterion of $5 \%$ leaking doors is not difficult, and $3 \%$ is probably attainable with moderate trouble and expense.

According to information from the American Coke and Coal Chemicals Institute, a majority of the existing batteries, perhaps 80\%, will be adapted to the 1993 or 1995 conditions. Hence, il can be assumed that little if any change will occur in the deliveries of coke, approximately 2 million tons per year, to the present steel mill customers up to the year 2003 and possibly beyond. 


\subsection{Prospects of the Captive Coke Industry}

From Table 3 it is possible to predict the status of the industry either for 1993 or 1995, but the period between these 2 years is uncertain. This is because of the existence of the two options for meeting the MACT standards: minagers confident of meeting the tougher LAER standard in 1998 and running their batteries beyond that year must meet MACT by 1993; those expecting to shut down in 2003, when the so-far-undefined risk standard will apply to their operations, have until 1995 to meet the MACT levels. Peters (2) assumed that batteries built before the Clean Air Act of 1970, older than 25 years in 1995, will be closed at the latest by 1995 . Two replacement batteries, presumably built to LAER standards, will have been built by 1995 or shortly thereafter. This information is summarized in Table 4.

About 26 million tons of coking coal will be needed for the 16.9 million tons of coke indicated in Table 4.

Estimates of the situation after 1998, the LAER year, are uncertain because of the probable construction of some batteries of the nonpolluting type. An estimate of the situation after 1998 is shown in Table 5.

\subsection{Cost of Construction and Upgrading of Batteries}

The cost of building a new large coke battery in the United States is estimated at $\$ 250$ to $\$ 300$ per ton of annual capacity; the practical limit of battery size is at the most 1.0 million tons per year. The cost of a nonrecovery battery is reportedly $\$ 200$ to $\$ 240$ per ton.

Costs of rebuilding or upgrading of coke batteries are quite variable because of the different degrees of work to be done, age of the battery, site specifics, etc. In 1987 (Federal Register, April 23, 1987), EPA estimated the cost of compliance to reach the 5\% maximum-leaking-doors-standard to be $\$ 3$ to $\$ 40$ million per battery.

\section{TABLE 4}

Age and Capacity of Steelmaking Coke Batteries after 1993-95

\begin{tabular}{cccc}
\hline Age, Years & $\begin{array}{c}\text { Number of } \\
\text { Batteries }\end{array}$ & $\begin{array}{c}\text { Capacity, } \\
\text { (Million Tons) }\end{array}$ & $\%$ \\
\hline 5 or less & 2 & 1.2 & 7.1 \\
6 to 10 & 2 & 0.6 & 3.6 \\
11 to 15 & 9 & 5.0 & 29.6 \\
16 to 20 & 14 & 8.5 & 50.2 \\
21 to 25 & 3 & 1.6 & 9.5 \\
Total & 30 & 16.9 & 100.0 \\
\hline
\end{tabular}




\section{TABLE 5}

Age and Estimated Capacity of Steelmaking Coke Batteries after 1998

\begin{tabular}{lccc}
\hline \multicolumn{1}{c}{ Age, Years } & $\begin{array}{c}\text { Number of } \\
\text { Batteries }\end{array}$ & $\begin{array}{c}\text { Capacity } \\
\text { (Million Tons) }\end{array}$ & $\%$ \\
\hline 5 or less (new batteries) & 8 & $5.0^{1}$ & 38.5 \\
6 to 10 (new nonpolluting & & & \\
batteries) & 4 & 3.0 & 23.0 \\
(upgraded batteries) & 8 & 5.0 & 38.5 \\
Total & 20 & 13.0 & 100.0 \\
\hline
\end{tabular}

1 Estimate by AISI.

Peters (2) quotes unpublished data from the AISI which indicate that the cost of meeting the MACT standard of $8 \%$ leaking doors would require the replacement of all doors and door jambs on all ezcept the newest batteries for an estimated average cost of $\$ 10$ million per battery. The AISI seems to have accepted the EPA estimate regarding the 5\% standard, but meeting a possible 3\% limitation would cause the closure of all batteries more than 30 years old, costing at least $\$ 250$ million each to replace and rebuilding others at a cost of about $\$ 100$ million per battery. Most steel companies would probably find such expenditures unacceptable. 


\subsection{ESTIMATE OF THE COKE SHORTFALL}

As discussed earlier, some coke ovens are likely to close, if only because of age. Producers must then decide whether to build new capacity, import coke, import steel, or consider new steelmaking technology. The process for estimating needed new coke capacity is illustrated in Figure 5. An estimate of total domestic steel demand begins the process. Figure 6 gives the historical United States production and consumption of steel. Technolugy changes (Figure 7) determine how mush coke is needed per average ton of steel produced. It was reported early this year that Geneva Steel in Orem, Utah, has shut down the last cperating open-hearth furnace in the United States. This brings to a final close the replacement of open-hearth furnaces with basic oxygen furnaces (BOF) and electric-arc furnaces, a process which began several decades ago. The open-hearth furnace has a heat time of about 6 hours, compared to 1 hour for the basic oxygen and electric-arc furnaces.

The increasing market share won by electric-arc furnaces, in combination with decreasing steel production, has resulted in sharply falling domestic coke production (Figure 8). Coke requirement per ton of BOF steel has actually remained fairly constant (Table 6).

Over the last decade, the number of coke plants and the number of batteries have decreased. In 1980, 60 coke plant locations had a total of 195 batteries. This total included 20 merchant coke plant locations with 47 batteries and 40 furnace coke plant locations with 148 batteries. Total production for these batteries in 1980 amounted to approximately 48 million metric tons of coke.

During the period from 1980 to 1991, the number of plants fell to 32, and the number of operating batteries present at coke plants declined by more than $50 \%$, to 90 batteries. During this period, at least one new coke battery was constructed and several batteries were modified. Total coke production, as shown in Figure 8, fell from about 48 million metric tons in 1979 to about 30 million metric tons in 1989. Production generally declined from 1980 to 1986, then rebounded slightly between 1986 and 1989. At its lowest level in 1986, coke production fell to 23.2 million tons, less than $50 \%$ of 1980 coke production. Coke production then gradually increased from 1986 to 1989 to about 30 million metric tons, approximately $62 \%$ of 1980 coke production.

Based on a projected demand for 60 million tons of BOF steel per year, the amount of coke needed is estimated in Table 7 and shown in Figure 8. Considering probable retirements, closures as a result of the CAAA, and new construction, Peters (2) estimates a coke shortfall of 6 to 7 million tons per year by 2003. This constitutes the basic opportunity for future formcoke production via mild gasification. It should be understood that the trend illustrated in Figure 8 is mostly a result of economic factors and not a specific result of the Clean Air Act Amendments of 1990. A detailed econometric analysis by Research Triangle Institute (1) concludes that by the year 2000 only one or two coke batteries will cease production as a result of the LAER standard, and only one small firm will incur significant economic impacts. 


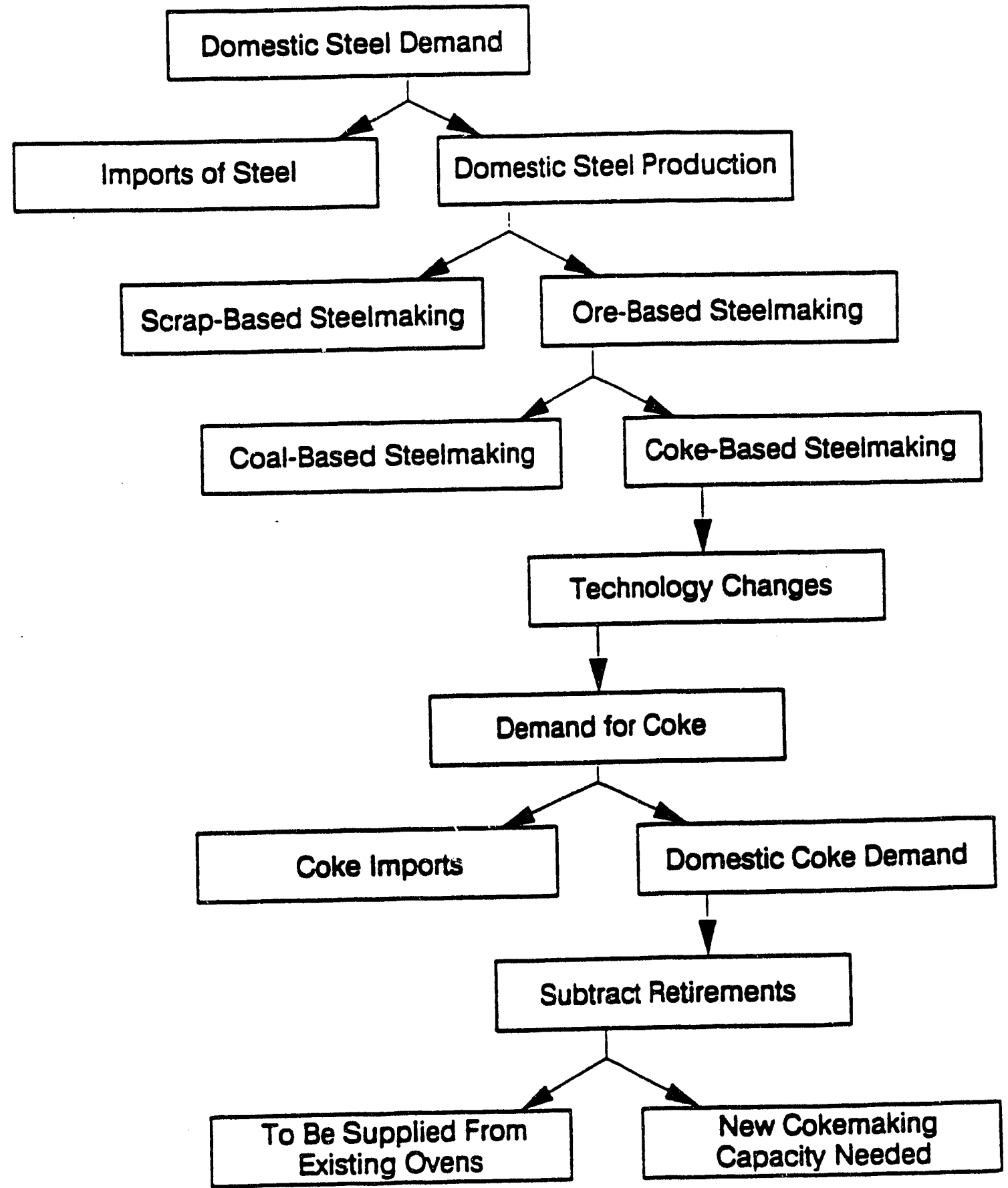

Figure 5. Estimation of new cokemaking capacity needed. 


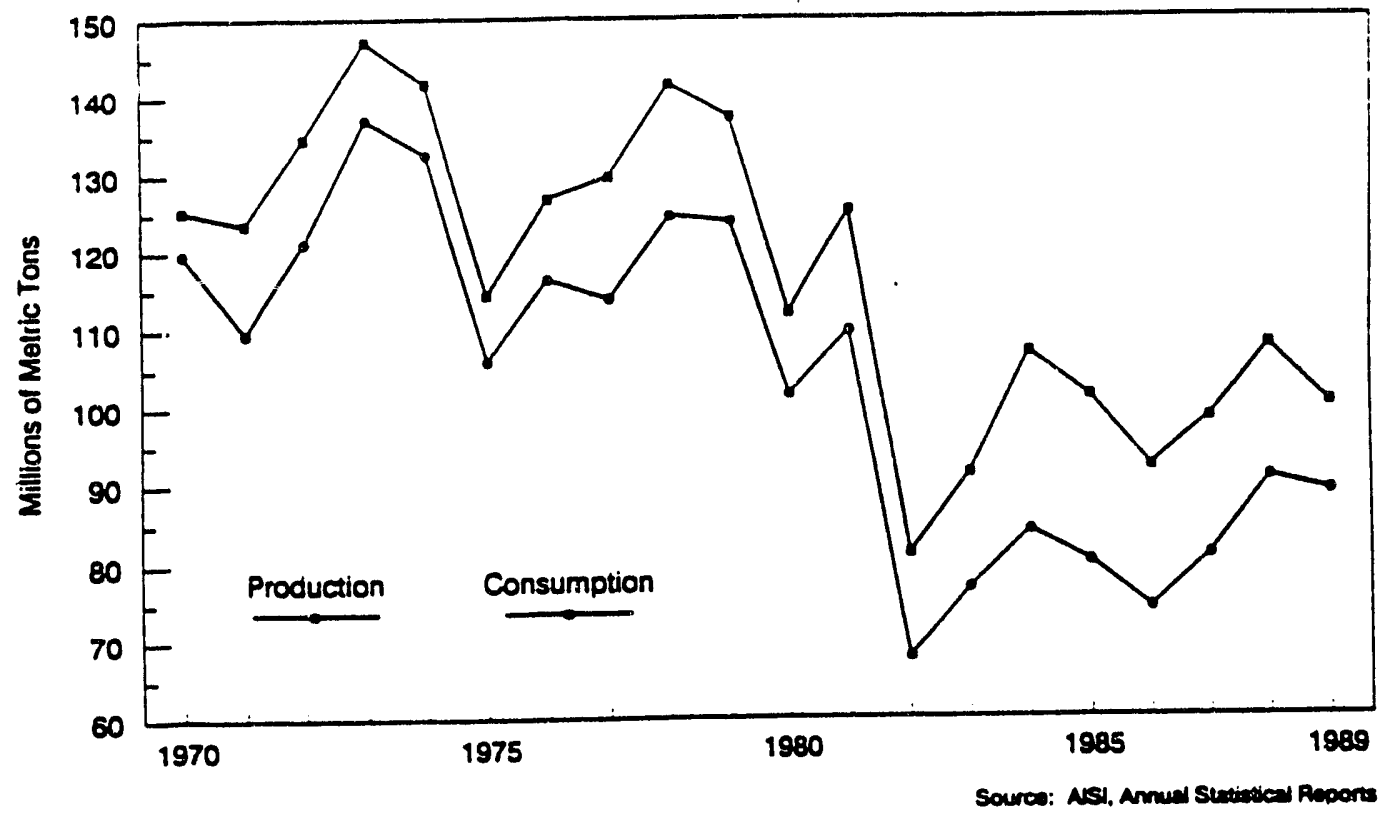

Figure 6. Total steel production and consumption in the United States.

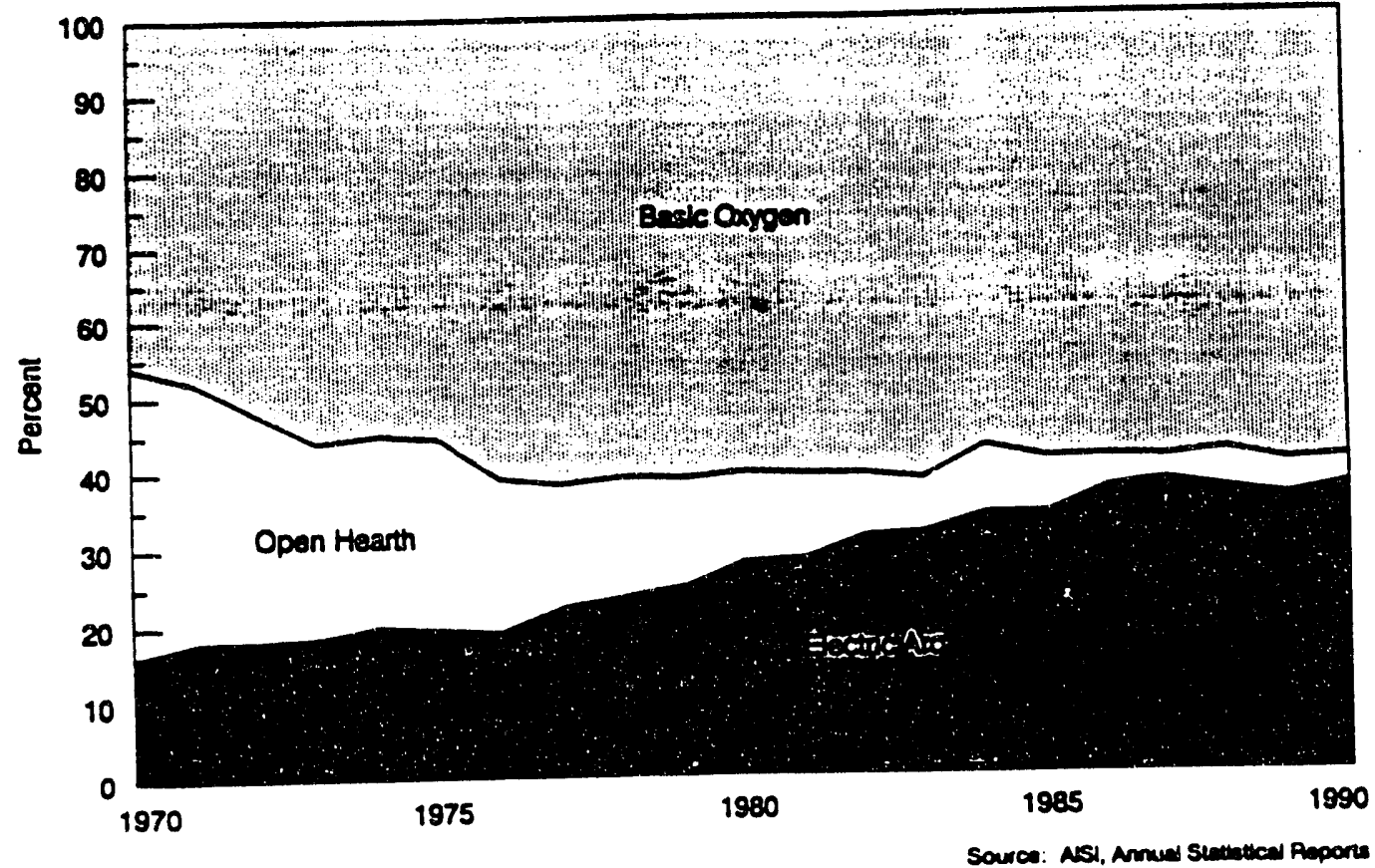

Figure 7. Share of steel production by technology. 


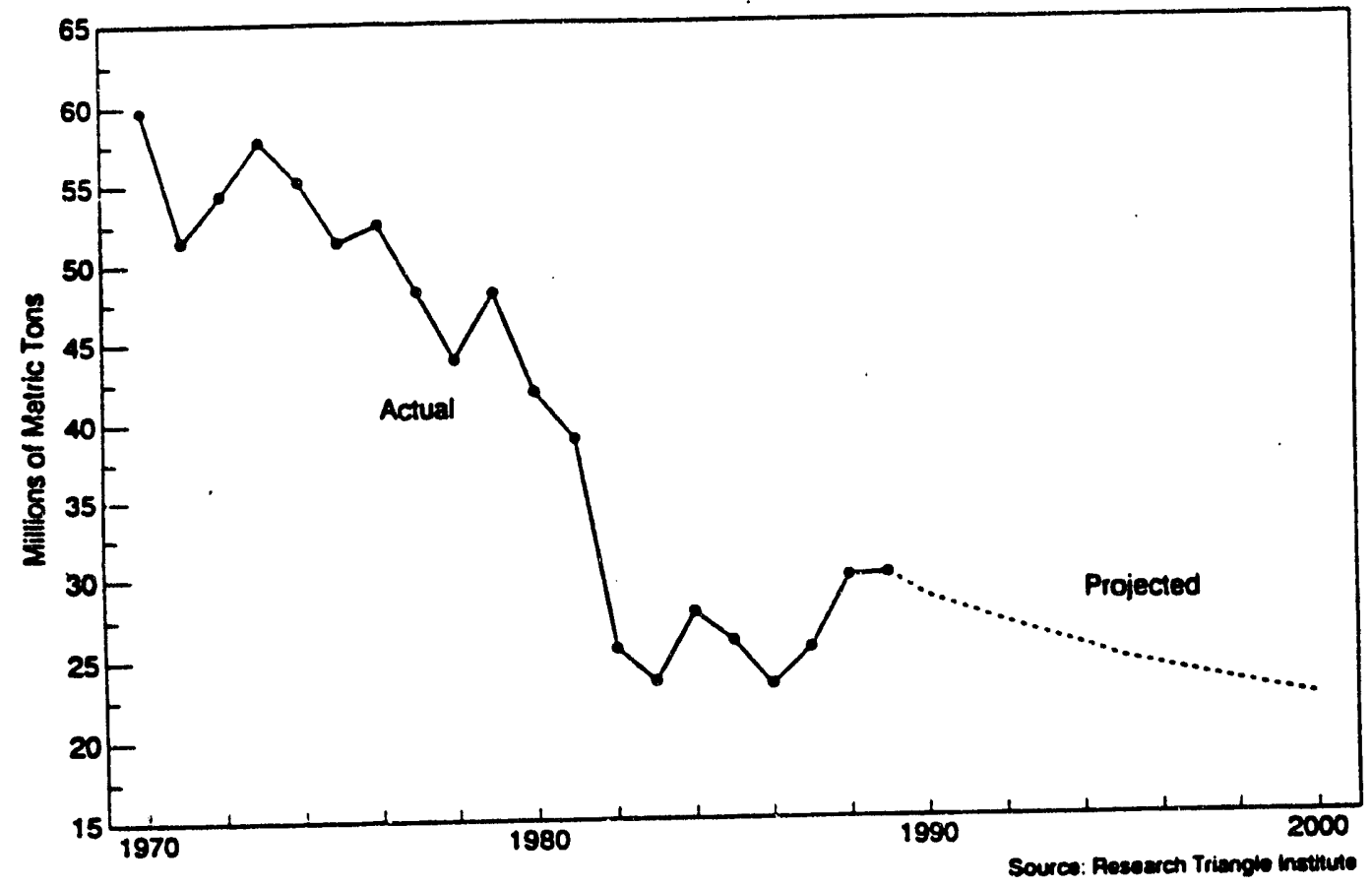

Figure 8. Coke production in the United States.

TABLE 6

Unit Consumption of Coke in the Production of Iron and Steel (Million Tons)

\begin{tabular}{lccccc}
\hline & 1985 & 1986 & 1987 & 1988 & 1989 \\
\hline Coke consumed in blast furnace & 25.6 & 22.3 & 25.5 & 29.4 & 29.2 \\
Iron made & 50.4 & 44.0 & 48.4 & 55.7 & 55.9 \\
Coke unit consumption, tons/ton iron & 0.508 & 0.507 & 0.527 & 0.528 & 0.523 \\
Steel made: & & & & & \\
Basic open-hearth furnaces & & & & & \\
Basic oxygen furnaces & 6.4 & 3.3 & 2.7 & 5.1 & 4.4 \\
Iron consumed: & 51.9 & 47.9 & 52.5 & 58.0 & 58.3 \\
& & & & & \\
Basic open-hearth furnaces & & & & & \\
Basic oxygen furnaces & 3.6 & 1.9 & 1.5 & 2.9 & 2.5 \\
Iron unit consumption, tons/ton BOF stoel & 0.88 & 0.86 & 0.87 & 0.89 & 0.91 \\
Coke unit consumption, tons/ton BOF stoel & 0.45 & 0.44 & 0.46 & 0.47 & 0.48 \\
\hline
\end{tabular}




\section{TABLE 7}

Estimated Total Coke Demand for 60 Million Tons of Raw Steel from BOFs

(For Flat Products) (Million Tons)

\begin{tabular}{lrrr}
\hline & 1995 & 1998 & 2003 \\
\hline Steel demand & 60 & 60 & 60 \\
Less: Flat products made by minimills & 3 & 5 & 5 \\
Less: Steel made from non-blast-furnace iron & 0 & 1 & 2 \\
Net BOF steel for flat products & 57 & 54 & 53 \\
Total required iron & 52 & 49 & 48 \\
Iron made with: & & & \\
$\quad 0.5$ ton coke & 41 & 25 & 16 \\
0.4 ton coke & 10 & 24 & 32 \\
Total coke demand & 25 & 22 & 21 \\
Less: Coke from independent producers & 2 & 2 & 2 \\
Coke needed & 23 & 20 & 19 \\
\hline
\end{tabular}

1 Blast furnaces equipped with coal injection.

\subsection{Alternative for Replacement of the Coke Shortfall}

The report by Peters (2) offers three scenarios to be considered:

- All the shortfall of coke is imported on a contract basis.

- Through joint ventures with foreign producers, probably on a $50 \%$ contract basis, all of the shortfall would still be imported, but $50 \%$ of it would be from joint venture operations at a reduced cost.

- Semifinished steel is imported. This would be attractive to companies with old, fully or nearly depreciated blast furnaces, steelmaking furnaces, and casters, which contribute little to the company cash flow.

The alternative of developing new cokemaking or substitute-cokemaking processes was not considered. We believe this should be the preferred alternative.

Moving the cokemaking capacity abroad relieves the manager of uncertainties due to changing federal and state rules and regulations and their interpretations, inspections by the EPA, OSHA, union representatives, etc., and possible litigations. Consequently, there will be a strong tendency toward moving the operations abroad.

In the future, an assumption of $\$ 150$ per ton delivered (in 1991 dollars) seems reasonable when importing 6 to 7 million tons against about $\$ 120$ per ton for the 2 to 3 million tons imported now. The price difference is simply the consequence of increased demand. On this basis, and assuming the capital cost of $50 \%$ ownership of foreign batteries to be $\$ 100$ per ton, a table of probable dollar outflows is presented in Table 8 . 
TABLE 8

Probable Cost of Replacement of the Coke Shortfall (In 1991 Dollars)

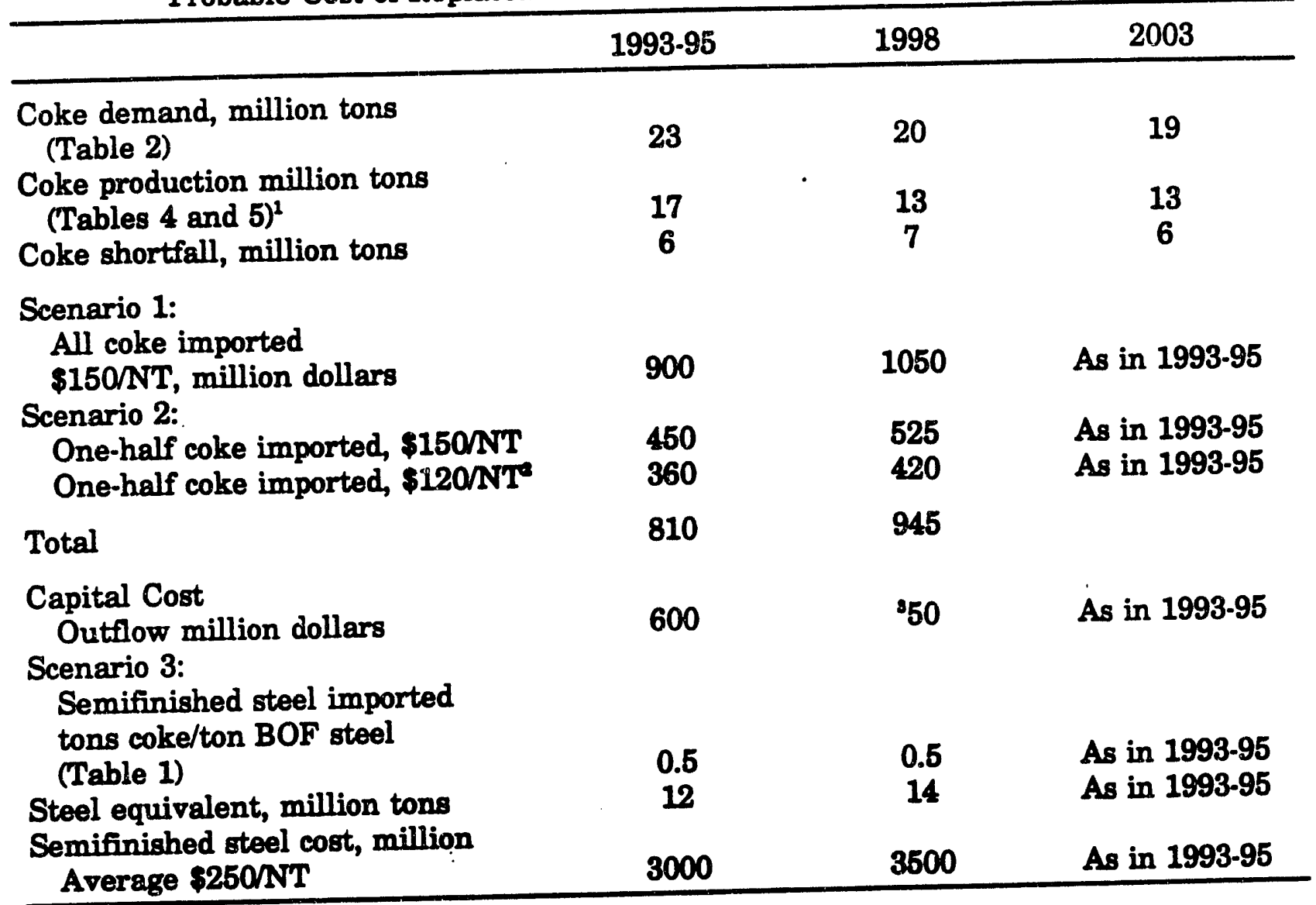

1 Assumes production at capacity.

2 From joint ventures, the $\$ 30$ difference allows for the dividend.

3 Additional.

Although an expenditure of $\$ 3$ to $\$ 3.6$ billion by the steel industry for semifinished steel may appear prohibitive, in actual practice it may be very attractive because it could replace, possibly even more than replace, the costs of making coke and iron, refining it into steel and casting.

In addition to the coke batteries, older, less efficient blast furnaces, basic oxygen steelmaking shop and continuous casters could be shut down.

The desirability of importing semifinished steel was demonstrated during the period 1986 to 1988 when steel plants had to import "semis" to keep up with the swollen order books. The steel was of good or very good quality and the prices, delivered, in general were at or slightly below U.S. manufacturing costs.

\subsection{Loss of By-Products}

The magnitude of the loss by by-products due to the shrinking of the industry can be roughly estimated from the amounts of coal coked and the average yields of by-products 
(shown in Table 9). The coke is used for ironmaking in blast furnaces; the breeze is burned or sold; coke-oven gas is used for underfiring ovens and reheating of steel. Tars are sometimes burned, but more often they are refined into numerous chemicals such as pitch, naphthalene, creosote, pyridine, acids, etc. Ammonium sulfate is a nitrogen-bearing fertilizer and ammoniacal liquor is usually also converted into some form of fertilizer. Light oils are the source of benzene, toluene, naphthas, and other solvents and chemicals.

\subsection{Coke Value}

Most furnace coke is used by the owners of the coke ovens and is never sold on the open market. Only one merchant coke producer is known to sell furnace coke. Therefore, data on coke prices are hard to come by. Because the Energy Information Administration no longer reports coke prices in its Quarterly Coal Report, it is not possible to update the coke price curve given in the 1988 market assessment report. That curve indicated a price of about $\$ 100$ per ton in 1986 . It is possible that the data included foundry coke, which sells for a lower price.

The 1988 market assessment included a 1985 report estimate from the National Academy of Engineering giving the full cost of production (including capital recovery) as $\$ 150$ per ton. In a 1991 report from Research Triangle Institute (1), an econometric model was developed which computed the marginal value of furnace coke to the steel industry. This measure was used as a proxy for price and was calculated to be $\$ 173$ per metric ton or $\$ 157$ per short ton. The same study reported market values for foundry coke as $\$ 155$ per metric ton. If new coke plants are to be built, or old plants extensively upgraded, coke prices will have to reach capital replacement values. These prices may never appear in public, but will be the internal transfer price applying to coke manufactured by the integrated steel producers for their own use. These are the hizhest prises for which a substitute cokemaking process could be considered economically feasible. If imports of satisfactory quality are available at a lower price, new plants may not be built and substitute cokemaking processes would have to be feasible at the lower price level.

\section{TABLE 9}

\section{Coke Plant Products}

One ton of coking coal typically yields:

Coke

1200 to $1400 \mathrm{lb}$

(60\% to $70 \%$ yield)

Coke breeze (fines)

100 to $200 \mathrm{lb}$

Coke-oven gas (calorific value approximately $500 \mathrm{Btu} / \mathrm{ft}^{\mathrm{s}}$ or one-half that of natural gas)

9500 to $11,500 \mathrm{ft}^{\mathrm{s}}$

Tar

Ammonium sulfate

or

Ammoniacal liquor

Light oils
6 to $10 \mathrm{gal}$

20 to $28 \mathrm{lb}$

15 to $35 \mathrm{gal}$

2 to $4 \mathrm{gal}$ 


\subsection{COMPETITION ANALYSIS}

\subsection{Less Polluting Cokemaking Processes}

This analysis clearly shows the need for new, nonpolluting process technology to make coke or coke substitutes for the steel industry. A formcoke made from mild gasification char would be one possibility. However, there are other possibilities. In 1990, the American Iron and Steel Institute Committee on Technology formed the Alternative Cokemaking Technology Survey Task Group. The Task Group's charge was to conduct a survey on current and future coking developments, evaluate their significance, and report back to the industry. The Task Group consisted of individuals from several U.S. steel companies. Individuals made trips to Europe and Japan to survey cokemaking process development efforts. Also, two professors were hired to conduct literature surveys and hold discussions with foreign university experts. To learn what was happening in the Soviet Union, the Task Group interviewed three recent emigres previously involved in such research in the Soviet Union. Finally, representatives from many different organizations made presentations and provided information to the Task Group.

In May 1991, the Task Group reported its conclusions regarding cokemaking process potentials. Those conclusions, plus information from other sources, are summarized in the following:

- Of most near-term interest in North America are the nonrecovery cokemaking processes.

- For the planning horizon of 8 to 12 years, certain formcoke processes may become attractive.

- On the longer-term, the Jumbo oven concept being developed in Germany or an advanced formcoke concept being developed in Japan may become viable.

\subsubsection{Nonrecovery Coking}

Nonrecovery coke ovens are of simple design with a semicylindrical "dome" shape and exist in various sizes; coal is charged into the hot ovens, and the coal gases are allowed to burn above the coal and are drafted into flues under the orens to produce coking from two sides. All gases are burned and conveyed through an exhaust system to a stack. Nonrecovery coke plants are in operation in the U.S., Australia, and India (and an experimental facility is under construction in Mexico); they mainly produce coke for foundries. The simple ovens are low in cost to construct; combustion eliminates the need for a by-product plant. Also, this combustion would nearly eliminate hydrocarbon emissions-the toxic emissions of conventional cokemaking.

The nonrecovery oven is, in a sense, a throwback to the old beehive coke-oven technology. One modern design, known as the Jewell version of Thompson nonrecovery coke ovens, is specifically mentioned in the Clean Air Act with an instruction to the EPA to evaluate it and consider it as a standard for new coke ovens. 
One such battery has been operating for 20 years in Virginia. In late 1990, one major steel producer, Inland Steel Company, announced a joint venture with the Sun Coal Company, owner of the technology, to build such batteries in its Indiana Harbor, Indiana, steel mill.

The term "nonrecovery" simply refers to the fact that no by-products are recovered. All the gases and chemicals evolved from the coal during coking are burned in and swept out of the oven by suction applied in the exhaust stack. The resulting negative pressure inside the oven prevents any escape of pollutants. There is also no dirty process water to handle.

The final exhaust can be passed through waste heat boilers to produce high-pressure steam that is used to drive power-generating turbines. Although the process would not produce any useful gaseous by-products, it recovers heat as a coproduct, ultimately in the form of electrical energy used by the mill, with any excess sold to outside interests.

Inland had announced that it expects to have the first battery operating in the mid-1990s and, pending the outcome of the trials, plans to convert all of its cokemaking operations to the new design. However, the project has currently been placed on hold. The initial capital costs are reputedly lower than those of a conventional battery, but the operating economics are not well known. A severe problem may be the fact that the space required is several times that needed for a standard battery with equivalent output.

A nonrecovery oven design developed by Pennsylvania Coke Technology, Inc., utilizes a proprietary incineration system and a high-temperature desulfurization system. The company has a 6000-ton-per-year initial facility in Mexico, which was scheduled for start-up in September 1991. The company plans to construct a 100,000-ton-per-year coke facility in Mexico.

In Australia, Kembla Coal and Coke Pty., Ltd, has been producing coke since 1914 in Mitchell-type nonrecovery coke ovens from which their present proprietary technology has evolved. They produce approximately 250,000 tons per year of foundry coke in nonrecovery coke ovens located in Mlawarra, south of Sydney (3).

The AISI Task Group said it appears that coke quality from nonrecovery ovens would be acceptable for small blast furnaces in that some nonrecovery coke is already used in such furnaces. Trials in large, modern blast furnaces have not been made. The operating facilities have no stack emissions controls, which would be required for new large facilities. Process control knowledge is rudimentary and may be inadequate to control coke quality. Waste heat recovery was tried and abandoned in Australia.

\subsubsection{Formcoke}

Formcoke processes take several shapes. Heating and partial coke steps serve to drive off some volatile organics that are processed to make binder needed for briquetting. Final coking usually takes place in a moving shaft or kiln, with quenching accomplished with water or heat gas. The Mansfield coking process uses a traveling grate stoker. 
There are many formcoke plants operating today to produce domestic fuel and carbon for the chemical industries. Though experimented with, common blast-furnace use is not practiced at this time. The process steps occur in a series of closed reactors, which allows for good emissions control. Of particular note is the continued pursuit of acceptable formcoke in Japan. The latest efforts include extensive trials at Kawasaki in 1992. These trials are to include blast-furnace quenching and dissection.

AISI says blast-furnace trials have generally found a limit to the portion of formcoke that can be used. Undesirable high-reactivity formcoke can be caused by the feed coals and the types of initial heating of the coal. Processes not using fluidized beds in these steps appear most capable of producing low-reactivity formcoke. The size and shape of briquettes, however, is considerably different from conventional coke and would require blast-furnace operating changes. Briquetted formcoke tends to be too impermeable and to roll in the blast furnace. The equipment is relatively complez, and the ability to use the by-product gases is important to the process economics.

is noted in the 1988 market assessment, the FMC formcoke process, a proven technology for western coal, has been in operation for over 20 years at Kemmerer, Wyoming, producing agglomerated coke briquettes for the manufacture of phosphorous. (See that report for a description of the process.) Inland Steel Company, in cooperation with Armco, USX, and others have successfully tested 30,000 tons of FMC formcoke (Table 10). Industry may prefer a blend of formcoke and oven coke, along with coal, additional gas or oil when necessary, to fulfill the fuel and coke requirements of blast furnaces.

TABLE 10

FMC Formcoke Tests

\begin{tabular}{clccl}
\hline Year & \multicolumn{1}{c}{ Test } & Hearth (ft.) & Tons & \multicolumn{1}{c}{ Results } \\
\hline 1973 & $\begin{array}{l}\text { Inland Steel Company } \\
\text { Supported by Inland, U.S. } \\
\text { Steel, Armco, Jones \& } \\
\text { Laughlin, and Mclouth }\end{array}$ & 26.5 & 18,000 & $\begin{array}{l}\text { Good operation } \\
\text { Ono week 100\% }\end{array}$ \\
$1972 \begin{array}{l}\text { British Steel Corporation } \\
\text { Cardiff, Wales }\end{array}$ & 18 & 3,000 & $\begin{array}{l}\text { 6 days } \\
100 \% \text { FMC coke }\end{array}$ \\
$1970 \begin{array}{l}\text { Inland Steel } \\
1967\end{array}$ & 26.5 & 270 & $\begin{array}{l}\text { Low dust, no operating } \\
\text { problems }\end{array}$ \\
& $\begin{array}{l}\text { Armco-Inland } \\
1962\end{array}$ & 18.5 & 9,000 & $\begin{array}{l}\text { Too dusty, fines formed, } \\
\text { low furnace productivity } \\
\text { and efficiency } \\
\text { Good but high wind } \\
\text { U.S. Steel Corporation, experimental }\end{array}$ \\
\hline
\end{tabular}


Interest in the FMC process appears to have revived somewhat since 1988. FMC and Davy-McKee, licensor of the FMC process, have an active sales program that they are currently presenting to iron and steel companies.

Davy-McKee also designs and builds coke batteries and blast furnaces so they have the interest and capability to develop formcoke projects. Although the FMC formcoke process has been commercialized with noncoking, noncaking western coals, it could probably handle eastern high-volatile bituminous coals by adding additional stages.

The FMC formcoke process uses a multistage fluid-bed reactor designed to carbonize noncoking coals. The pitch produced is used as a binder in the briquetting process. The Kemmerer facility was built as a 50,000-ton-per-year pilot plant, expanded to 80,000 tons per year over a period of several years and recently expanded to 120,000 tons per year with the removal of minor bottlenecks.

Several other formcoke processes developed in the past are listed in Table 11. Some concern has been expressed that formcoke may not have high enough strength to be used in larger blast furnaces. In "Coke Test after Reaction Test" coke samples are exposed to CO. This test tends to destroy the more reactive formcoke, which subsequently fails the tumbler test. An alternative strength test has been proposed for formcoke.

\subsubsection{Jumbo Coking}

The Jumbo reactor concept is being pursued by a European consortium led by the German Bergbau Forschung Institute. The reactor is basically a large slot coke oven. However, each oven is individually supported, heated, controlled, and operated. Each oven could produce 100 tons or more per batch.

The large oven size results in lower door, standpipe, and other oven surfaces to leak per ton of coke. Great attention is being paid to buttressing the oven walls to prevent premature failure. In general, the carbonization phenomena are expected to be the same as in conventional slot ovens, so coke quality limitations are not expected.

Two large prototype ovens are under construction in Germany. Though information is preliminary, capital costs and land use may be somewhat higher than for conventional coke plants. Also, because each oven in a bank of ovens would be individually controlled, coordination of the operations might be complex.

\subsubsection{Advanced Formcoking}

A Japan National Project was begun 4 years ago with the goal of further advancing formcoke technology. The approach is to develop a process to meet two critical energy needs--coke and liquid fuel. The process is envisaged to extract coal compounds for processing into fuels and then to process the remaining coal material for cokemaking via briquetting and carbonization. Special attention is being paid to avoid destroying the carbon form-producing components of the coal that are necessary to produce low-reactivity coke. 


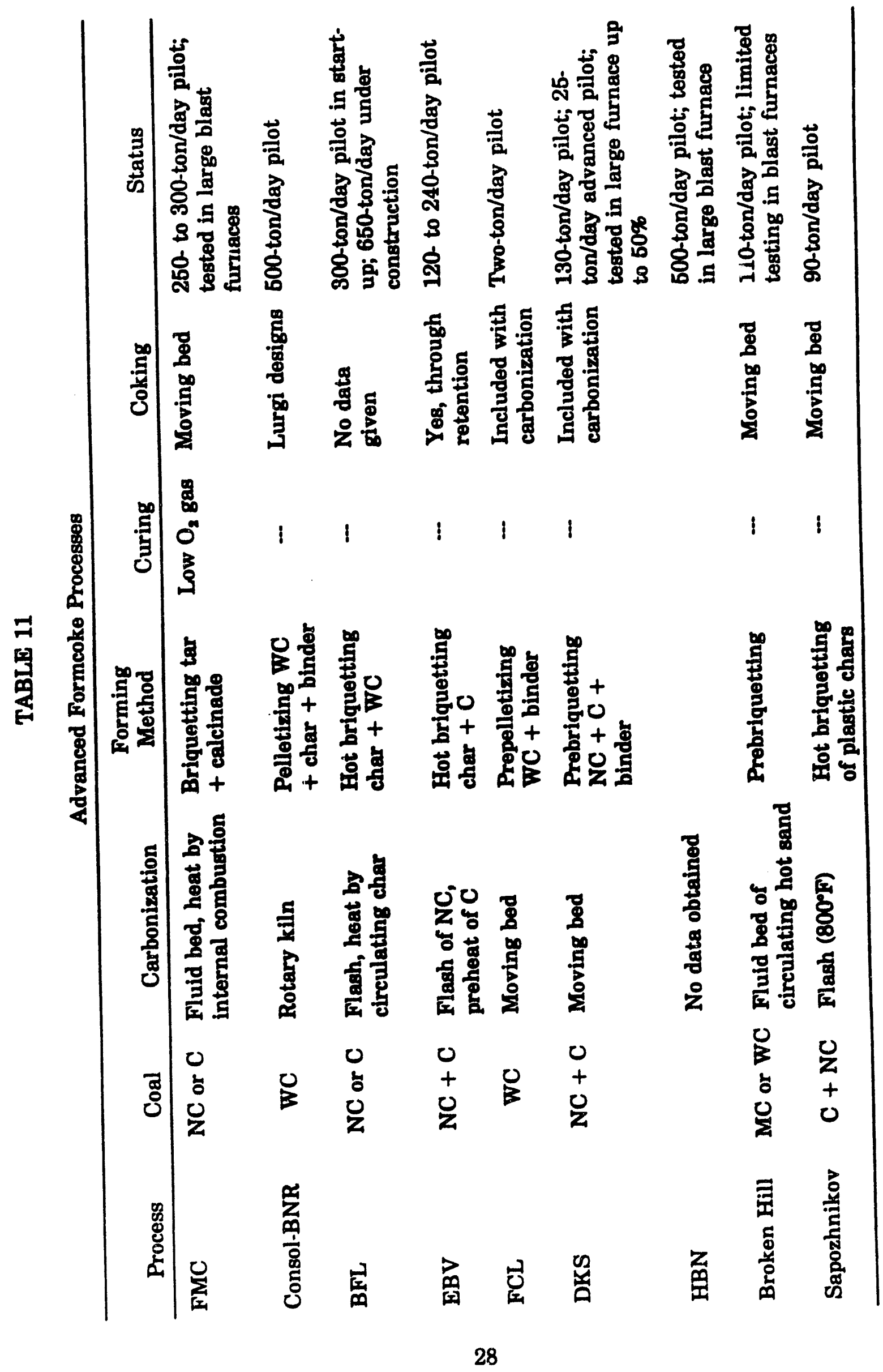


The fuels planned to be produced include diesel fuel and gasoline. Eliminating the partial carbonization step altogether gives the process the capability to produce low-reactivity coke from the right types of coals. Like other formcoke processes, the reactors used should make environmental control easier.

The development work on advanced formcoking is currently at the stage of studying the necessary reactions. The work has not progressed to the point of a prototype unit. It would be anticipated that both capital and operating costs would be higher than for other formcoke processes due to the solvent extraction steps. Also, exactly what fuels will be produced, and at what quality, is not yet clear.

\subsubsection{Other Findings}

Besides the findings about different cokemaking processes, the Task Group realized that cokemaking research in North America has begun to lag behind that elsewhere over the past 10 years or so. Most other countries with large steelmaking plants support industry-wide research organizations and universities. The U.S. alternative of extensive corporate research efforts has all but vanished.

AISI concluded that if standard formcoke processes, as tested by Kawasaki, and nonrecovery cokemaking, as evaluated by American steel companies, are found to be not suitable, then other cokemaking process development needs to be conducted. This would be difficult in North America because of the recent demise of cokemaking research. Thus the potential value of a formcoke process based on mild gasification appears to be confirmed. 


\subsection{NONCOKING PROCESSES FOR MAKING STEEL}

The 1988 market assessment report outlined several alternative approaches to steelmaking which could eliminate the need for a cokemaking step. These consist of direct reduction and direct smelting processes. There has been no basic change since 1988 , although the technology continues to progress slowly.

\subsection{COREX Process}

In 1988 and 1989, the first COREX plant was commissioned and started up at ISCOR's Pretoria works in South Africa. Designed and built by Voest-Alpine Industrieanlagenbau $\mathrm{GmbH}$ (Linz, Austria), the plant converts iron ore and coal directly into 300,000 tons per year of pig iron in a melter-gasifier. Production costs at the Pretoria plant are said to be $30 \%$ lower than conventional method costs.

In the COREX process, two separate streams of materials are gravity fed into the melter-gasifier. One stream is coal plus lime. The second stream--iron ore in lump, sinter or pellet form--is first fed to a reduction furnace at $850^{\circ}$ to $900^{\circ} \mathrm{C}$ and contacted with reducing gas from the melter-gasifier. This step reduces the ore to $95 \%$ sponge iron metal. The sponge iron proceeds to final reduction and melting in the melter-gasifier, where temperatures range from $1100^{\circ} \mathrm{C}$ near the top of the unit to $1500-1700^{\circ} \mathrm{C}$ at the oxygen inlets near the bottom. Molten metal and slag are tapped from the bottom. Voest-Alpine says the pig iron quality matches that from blast furnaces.

There still is no project under way in the United States to utilize the COREX process. It was noted in 1988 that two such projects had been proposed under the Clean Coal Technology Program, one by Weirton Steel and one by USX. Neither was successful. Since then, COREX projects have been proposed by Geneva Steel and by Virginia Iron Industries. However, both of these projects have also failed to materialize. The Virginia Iron project was canceled in 1991. LTV Steel also has been considering the process.

\subsection{Other Direct Smelting Processes}

Japan's Iron and Steel Federation will install a $\$ 50$ million, 500-tonne-per-day coal-based direct ironmaking pilot plant in NKK's Keiyo works in Kawasaki City with scheduled start-up in 1993. Summarizing the steps involved, ore pellets are first fed into a fluidized-bed reduction furnace, while coal is injected from near the bottom of the unit. Partially reduced ore and tar move from the chamber into a smelting reduction furnace. Simultaneously, coal is fed into the furnace and oxygen injected through a lance.

In Australia, CRA Ltd. and Midrex Corporation are building a 150,000-metric-ton per-year demonstration plant, to be completed by 1995 , for a direct ironmaking process called Hismelt. It uses injected coal and oxygen to produce iron; surplus $\mathrm{CO}$ from the reactor helps prereduce ore fines in a fluidized bed.

A direct steelmaking process is being developed in the United States under the direction of the American Iron and Steel Institute, with joint funding from eight domestic steel makers and the United States Department of Energy. Begun in 1989, the 4-year project involves a two-stage process where iron ore pellets are prereduced with hot gases in one vessel and then transferred to a second vessel containing molten iron where coal 
and oxygen are injected. It is referred to as a continuous reaction bath smelting process. Developers say the process could cut energy use by $20 \%$, capital costs by $50 \%$, and production costs by $10 \%$.

\subsection{Direct-Reduced Iron}

Electric-arc furnaces continue to win market share (Figure 7). Because they use no coke, coke demand falls in proportion. The market share achievable by electric-arc furnaces, however, is limited because they rely on steel scrap as feedstock rather than iron ore. The buildup of other metal impurities in steel scrap as it is recycled several times also limits the products that can be made by electric-arc furnaces. Electric-arc furnaces can avoid the scrap trap by using some direct-reduced iron (DRI) as feedstock. There is still only one DRI plant in the United States, operated by Georgetown Steel Corporation in South Carolina. It uses a process developed by Midrex Corporation based on natural gas. It is unlikely that additional such plants will be built in the United States, but Midrex is also working on a coal-based DRI process called Fastmet (4). In Fastmet, finely crushed iron ore and coal are mixed with water and a bentonite binder and pelletized in a drum. Pellets are partially predried with air before they go into a rotary hearth furnace. Overfire burners heat the pellets to gasify the coal and produce reduction gases. In conventional processes, pellets are fired directly at high temperature.

The installation of continuous casting at blast furnaces has reduced the amount of high-quality in-house scrap available and, therefore, reduced the amount of high-quality scrap available for electric-arc furnaces. This suggests that DRI demand will increase significantly, and new facilities will be built, particularly in countries with low-cost gas supplies. Figure 9 shows DRI production trends and projections (5).

\subsection{Other Processes}

A number of other alternative smelting processes were identified in the 1988 market assessment report, and work continues on some of them. Refer to that report for more details. Japanese firms are vigorously pursuing coal technology and have filed for more than 1000 Japanese patents on direct iron-smelting processes.

Also, the direct injection of coal into blast furnaces continues to grow. Direct injection of coal can replace up to about $30 \%$ of the coke needed in a blast furnace.

\subsection{Summary}

Although technology for making iron and steel without the need for coke is improving, it is clear from the rate of progress that conventional blast furnaces requiring coke will continue in existence for a long time. Blast furnaces should continue to dominate the world's molten iron production for the next 20 to 25 years. Therefore, there will continue to be a need for coke, produced in the least-polluting manner possible. 


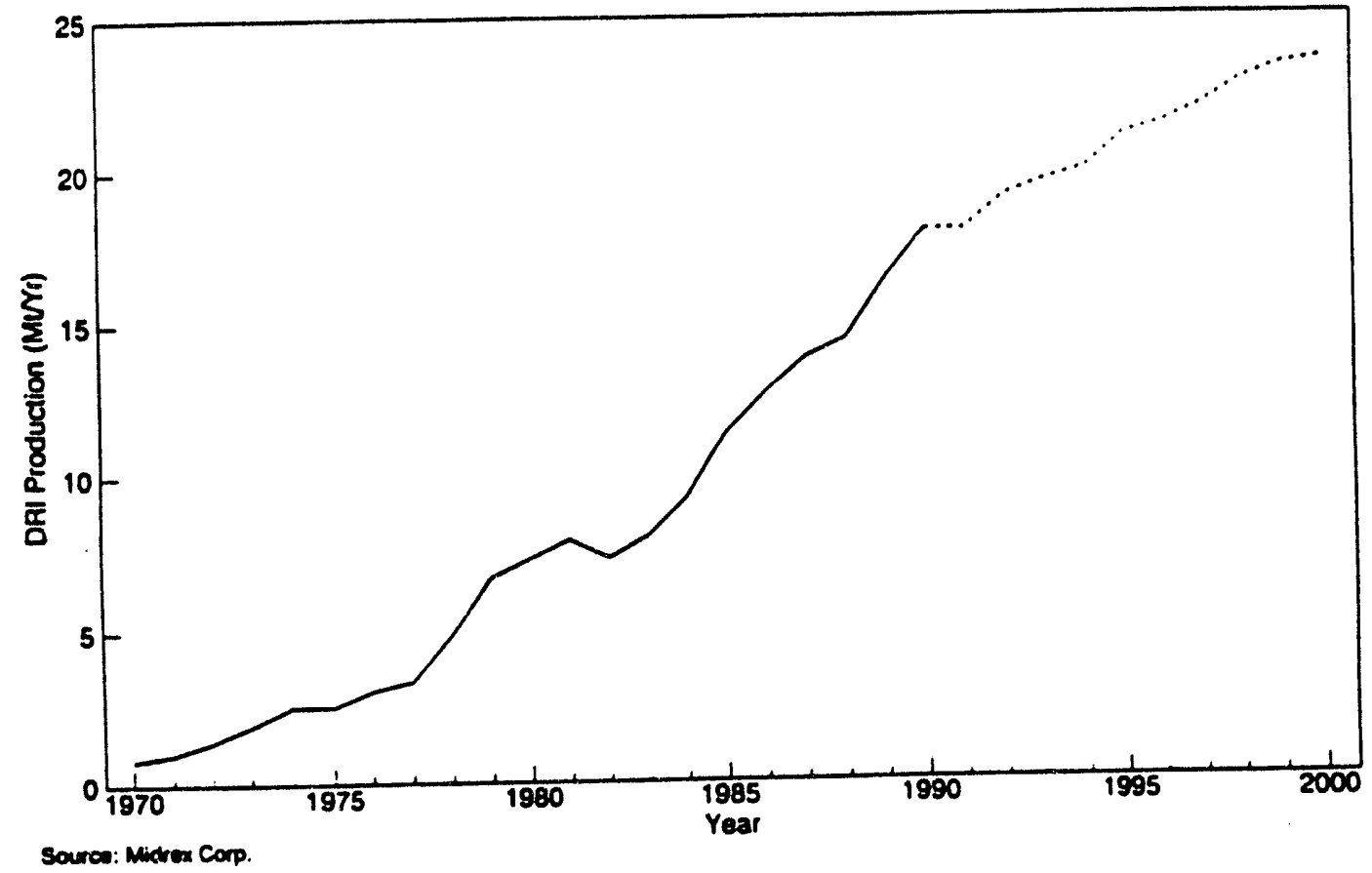

Figure 9. World direct-reduced iron production. 


\subsection{MGP FORMCOKE MARKET OPPORTUNITY}

\subsection{Steel Industry Outlook}

The steel industry has been through a difficult restructuring during the $1980 \mathrm{~s}$, having to meet lower-cost foreign competition, making massive investments to install new, more-efficient technology, and coming up with innovative methods to cut energy and material costs. It has suffered through the worst of its restructuring, replaced the old open-hearth furnaces with basic oxygen furnaces, begun firing supplemental fuel in blast furnaces to reduce coke demand, and continues to make product improvements.

Figure 7 showed how the electric-arc furnace and basic oxygen furnace have replaced the open-hearth furnace over the past 20 years. Continued growth of electric-arc furnace output will be limited by the cost of electricity, availability of scrap metal, and limitations imposed by impurities in scrap. Blast furnaces have maintained or increased their percentage of production in a declining market. Until direct iron reduction or direct steelmaking become commercially proven processes, blast-furnace operations will continue, and there will continue to be a need for coke.

Figure 10 shows a 15-year decline in domestic steel production. Steel demand and supply appeared to have reached a new equilibrium in 1988 to 1990 to which the industry has structurally adjusted. If so, production levels will be maintained until new competitive forces shift the equilibrium again. Production dropped significantly in 1991, but demand should increase in the future with infrastructure rebuilding in the U.S., Japan, and Europe.

When the 1988 market assessment report was written, the United States steel industry had reported 5 consecutive years of heavy losses. Nevertheless, the report concluded that most of the restructuring problems were over, and that the industry was on the road to recovery. These expectations were generally borne out, as the industry returned to profitability in 1987 and again in 1989 (Figure 11). These encouraging results, however, were somewhat negated as the economic recession threw the industry back into a small loss position in 1990 and then a large loss in 1991. Because the latest losses are considered to result from cyclic factors in the economy, rather than from the massive restructuring that took place in the early 1980s, the outlook is for improved performance as soon as general economic conditions improve. Some analysts predict a break-even position in 1992 and a return to profitability in 1993. For the purposes of this study, near-term performance is important only to the extent that it may encourage or discourage investment in new technology. On this issue, the prognosis seems favorable. New investments are being made in areas such as continuous casting, better process control, and new rolling technology. There appears to be a higher level of confidence in the future of the industry than was the case 4 years ago.

The largest uncertainty at the moment concerns the effect of the expiration of the Voluntary Restraint Agreements (VRA) on steel imports as of April 1992. President Bush refused to extend the VRA, which had been in effect since 1984, and had limited steel imports from 27 countries to a total of $20.3 \%$ of the market. Even though actual imports in 1991 were below the 20\% cap, many steel producers fear a flood of imports now that the VRA has expired. Increased imports would, of course, reduce the coke forecast 


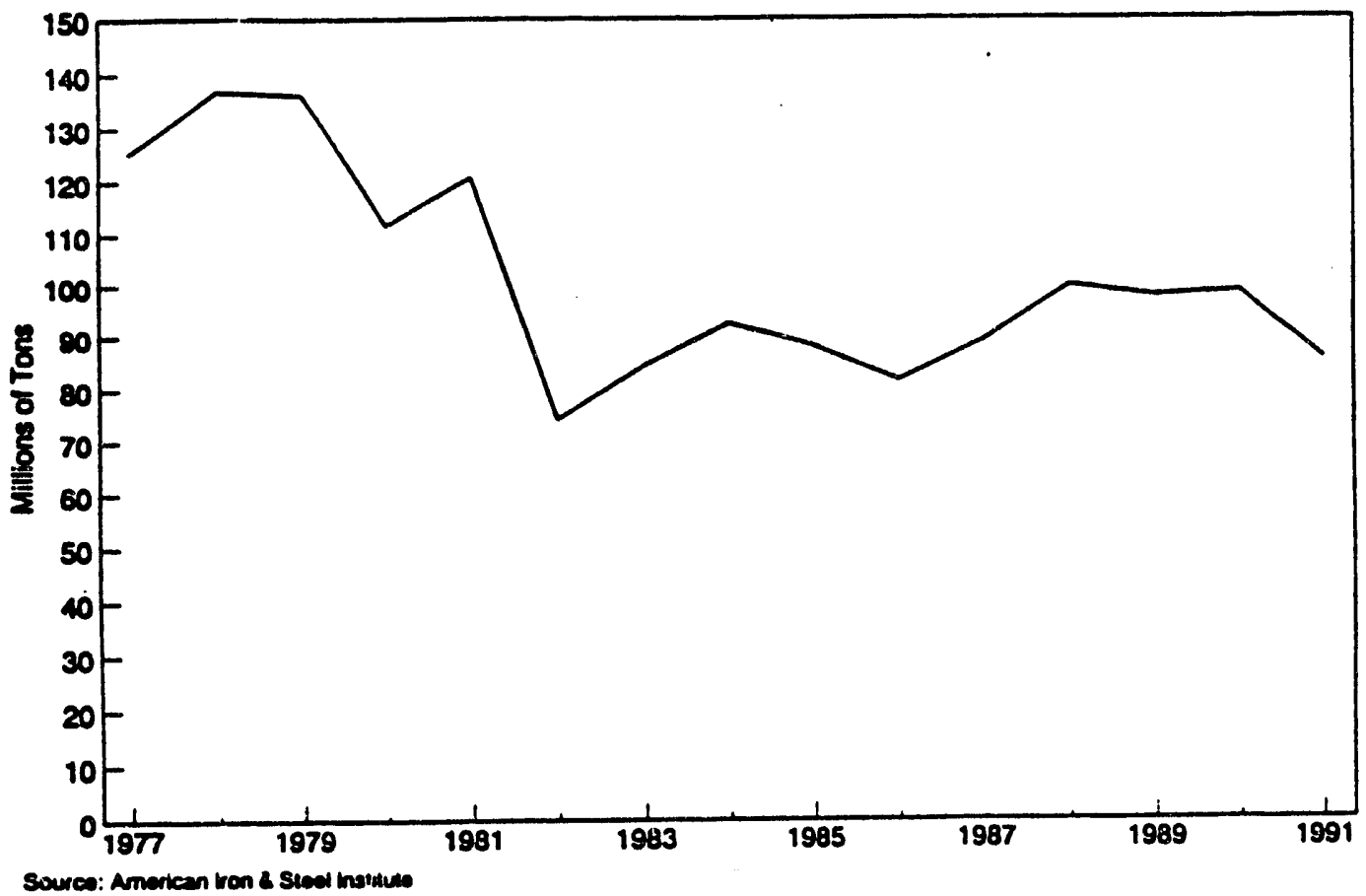

Figure 10. United States raw steel production.

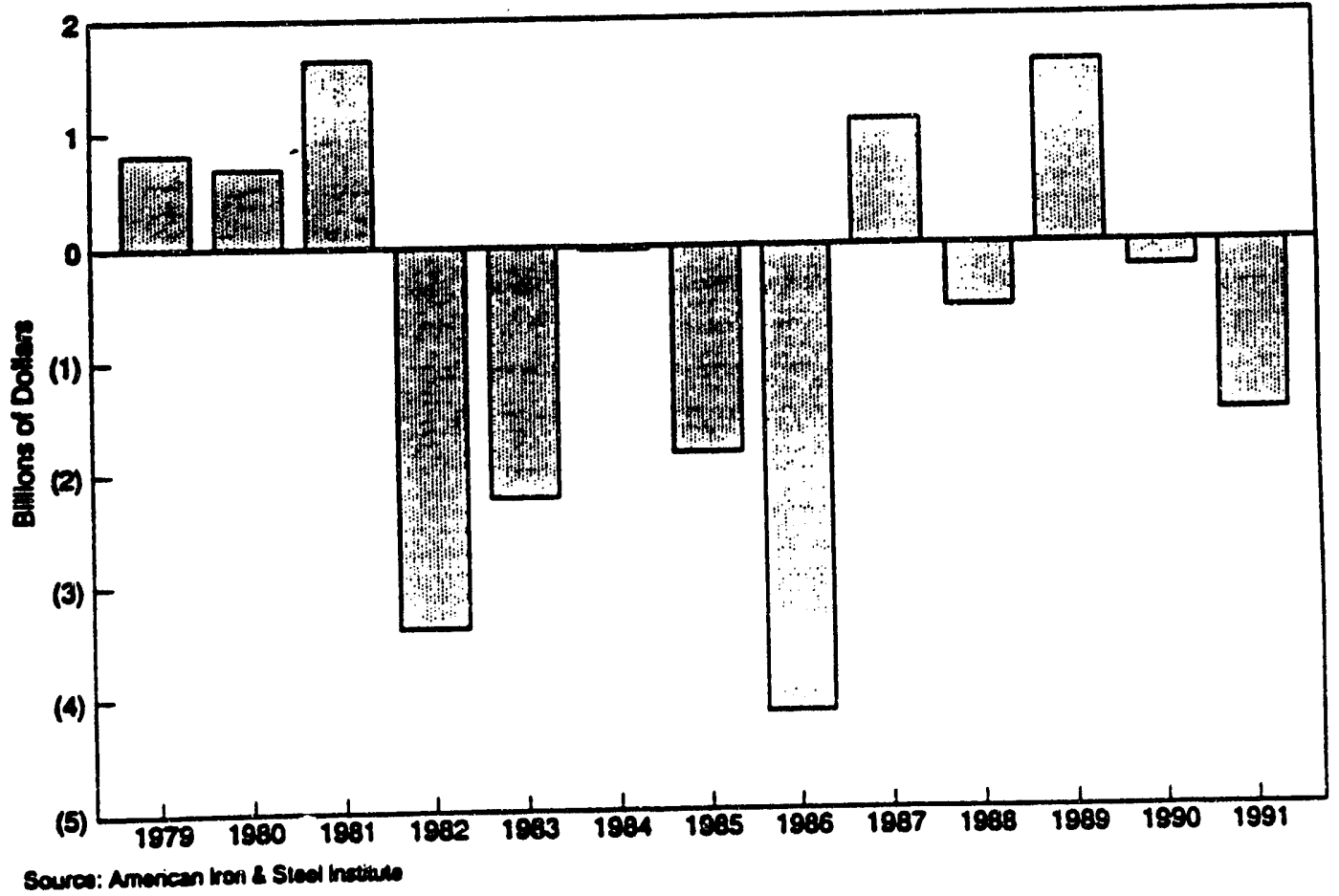

Figure 11. Steel industry net income. 
(Figure 5), but it seems likely that any large increase would again trigger political pressure to instigate some kind of limit. Meanwhile, multilateral talks involving 36 countries to try to dismantle trade barriers in the global steel industry broke down in March. The United States steel industry has threatened to initiate a large number of antidumping complaints against various countries.

Raw steel production in 1991 fell approximately 13\% from the year before, and capacity utilization (output as a percentage of raw steelmaking capacity) dropped to only 72\%. The U.S. Department of Commerce (6) expects shipments to increase about $4 \%$ as the economy climbs out of recession (Table 12). The steel industry will benefit from higher consumer spending for motor vehicles and appliances and some improvement in the capital goods industries. However, this forecast would place shipments well below the plateau recorded during the final 3 years of the last economic cycle (1988 to 1990) and reflects the expectation of sharply lower activity in the nonresidential construction market. No significant shifts in trade are expected.

By the mid-1990s, shipments of steel mill products are likely to reach their 1988 to 1990 level. With modest economic growth projected during the next 5 years, overall demand should be in the range of 82 to 92 million metric tons. No extraordinary rise in imports and import penetration is expected.

The rate of decline in the use of steel in the economy appears to be lessening. Moreover, because of competitive pricing and the development of new steels with such properties as corrosion and dent resistance, steel is retaining its share in many domestic markets.

The removal of trade barriers in Mexico, either as a result of a multilateral steel agreement or the proposed North American Free Trade Agreement, would provide important trade benefits to U.S. steel companies. Mexico's high tariffs are frequently cited by U.S. producers as the greatest impediment to increasing trade with that country. Relazation of "Buy Mexico" regulations pertaining to government projects and parastatal firms would likely provide opportunities to pipe and tube producers for sales to energy development projects.

\section{TABLE 12}

Steel Mill Products Trends and Projections

(in Millions of Metric Tons Except as Noted)

\begin{tabular}{lrrrrrrr}
\hline Item & 1981 & 1987 & 1988 & 1989 & 1990 & 1991 & 1992 \\
\hline Raw steel production & 109.7 & 80.9 & 90.6 & 88.8 & 89.7 & 78.0 & 81.0 \\
Continuous casting (\%) & 21.6 & 59.8 & 61.3 & 64.8 & 67.3 & 76.0 & 77.0 \\
Steel mill product shipments & 80.3 & 69.6 & 76.1 & 76.3 & 77.2 & 70.0 & 72.7 \\
Exports & 2.6 & 1.0 & 1.9 & 4.2 & 3.9 & 5.4 & 5.0 \\
Imports & 18.1 & 18.5 & 19.0 & 15.7 & 15.6 & 15.0 & 15.5 \\
Apparent domestic consumption & 95.8 & 87.1 & 93.2 & 87.8 & 88.9 & 79.6 & 83.2 \\
Exports as a percentage of shipments & 3.2 & 1.4 & 2.5 & 5.5 & 5.1 & 7.7 & 6.9 \\
Imports as a percentage of apparent & & & & & & & \\
$\quad$ consumption & 18.9 & 21.2 & 20.4 & 17.9 & 17.6 & 18.8 & 18.6 \\
\hline
\end{tabular}




\subsection{Formcoke Market Potential}

Formcoke sales to the iron and steel industry might be considered unattractive because coke is projected to be a declining market. However, if formcoke could capture a major percentage of the 25-million-ton-per-year demand, this would be an excellent business. The basis for considering formcoke as an alternative to conventional metallurgical coke has changed since the 1988 market assessment was made. In the past, formcoke was considered only because it had been hoped that it would be more economical. Now, the major reason for reconsidering formcoke is its potential as a less-polluting alternative. There is a better chance of justifying the process on an environmental basis than on a replacement investment basis.

Some reviews of the provisions of the Clean Air Act Amendments of 1990 suggest that there will be no immediate impact on the coke industry and that there may be little impact during the next 20 years. Industry and government representatives are currently negotiating promulgation of the regulations scheduled for December 1992. Until these regulations are actually promulgated, the exact effects will be unknown. However, it would appear that there could be a potential future need for several million tons of formcoke per year.

The market potential for formcoke could be augmented by diverting some production to make various forms of activated carbon. Figure 1 is a conceptual integrated carbon production and utilization scheme: gasification to produce formcoke or activated carbon from the char; conventional recovery of liquid products; use of the pitch as a binder for formcoke briquettes, activated carbon pellets or granules; and, finally, use of the spent carbon for its fuel value. The activated carbon is sold to the growing water treatment industry and the emerging activated char absorber market. Activated carbon is discussed in the next section. 


\subsection{ACTIVATED CARBON}

The 1988 market assessment included an extensive analysis of activated carbon as a potential product to be made from mild gasification char. Although the current conceptual design for a 1000-ton-per-day mild gasification plant does not include activated carbon as a product, it would be possible to consider activated carbon as an add-on byproduct or co-product. The total United States market demand for activated carbon is not large enough to absorb the entire output of even a 1000-ton-per-day mild gasification plant, so it cannot be the driving force for process development. Once such a plant is in place, however, the availability of a large stream of hot char which could be tapped for activated carbon production would offer attractive economies of scale.

A discussion of activated carbon production processes and uses was presented in the 1988 market assessment report and will not be repeated here. An update of the market information is presented in the following.

\subsection{Manufacturing}

Almost any carbonaceous material can be converted into an "activated" carbon product, although the adsorptive properties vary greatly, depending both on the raw material and on the processing conditions used. The starting materials used in the vast majority of industrial production operations, however, are coal, coke, wood chips or sawdust, coconut shells, petroleum fractions, and peat. Selection of the raw material is determined chiefly by the characteristics desired in the end product, the processing technology required, and its attendant operating and equipment costs. Liquid-phase carbon (activated carbon for use in liquid media) is most often made from wood or coal, while vapor-phase carbon (activated carbons for use in gaseous media) are usually made from coconut shells or coal and petroleum residues. The purchase cost of the carbonaceous raw material is usually a relatively small (e.g., 20\%) fraction of total product cost.

The two most common methods of activating a char are:

- Treatment with chemicals to remove residual volatiles and solubles.

- Thermal treatment with an oxidizing gas, usually steam.

Chemical activation is mostly used to produce liquid-phase carbons, both coal and lignite-based granules, or light, fluffy powders based on low-density raw materials like sawdust or peat.

In the gas activation process, to enlarge the pore size and increase the surface area, the carbon is activated with steam, carbon dioxide or flue gas at temperatures between $800^{\circ}$ and $1100^{\circ} \mathrm{C}$. Thus hot char could be treated as it exits a mild gasification reactor to save heatup costs.

Steam activation or selective oxidation can be used to produce both liquid- and gas-phase carbons. In both cases, the raw material is activated in granular form. Some gas-adsorbent carbons are made from hard, dense materials like fruit pits and nutshells. They are carbonized, crushed to size, and activated directly to give hard, dense granules of carbon. When charcoal, coke, or coal are used, these raw materials are usually crushed to a powder, formed into briquettes or pellets with a tar or pitch binder, crushed to size, 
calcined at $500^{\circ}$ to $700^{\circ} \mathrm{C}$ and then activated with steam or flue gas at $850^{\circ}$ to $950^{\circ} \mathrm{C}$. This method gives more easily activated particles, because they possess more macropores for the reaction products to leave from the center of the particles and for the oxidizing gases to enter.

Liquid-phase activated carbons typically have pore-size distributions with a larger portion of the total pore volume in transitional ranges, i.e., from 50 to over $1000 \AA$ Gas-phase carbons have more of the pore volume in micropore ( 3 to $50 \AA$ ) and macropore $(1,000$ to $50,000 \AA)$ ranges. Liquid-phase carbons tend to have larger total pore volumes, but about the same surface areas as gas-phase carbons.

\subsection{Liquid-Phase Applications}

Activated carbons in liquid-phase applications can be used for removal of certain categories of organics contaminants and selected inorganics. Nonpolar organics are more readily adsorbed than polar compounds. Smaller compounds with fewer than three carbons are more readily adsorbed than larger organic molecules due to pore-size sieving effects. Humic substances are, in general, poorly adsorbed, and, therefore, carbons do not effectively prevent these halomethane (THIM) precursors from reacting with halogen disinfectants. However, activated carbons do a better job of removing THMs once they are formed as disinfection by-products. Practical application information is still somewhat contradictory on this, however.

Regarding metals and inorganics, activated carbon is reported to be effective with such metals as antimony, arsenic, bismuth, chromium, morcury, silver, cobalt, and zirconium. Other metals receiving great attention in drinking water, such as lead, copper, cadmium and radium, are poorly adsorbed by activated carbons unless first complexed. Activated carbon is quite effective in removing the halogens, chlorine, bromine, and iodine, and is also effective in fluoride removal.

A developing use for activated carbon is in water treatment plants as a replacement for filter media or in integrated filtration systems. Point-of-use drinking water treatment cartridges containing activated carbon are also now commonly available for consumer use in homes.

\subsection{Gas-Phase Activated Carbon Applications}

Regarding gas-phase applications, more and more uses are being developed. As air pollution rules become tighter and more broadly applicable to industrial and coinmercial enterprises, sorbents such as activated carbon will be used more and more. Solvent recovery is becoming mandated in airsheds with ozone and photochemical haze problems. Air toxics rules for the latest revisions to the Clean Air Act will also result in more restrictions on releases of volatile organics. These controls are being achieved commonly by the use of activated carbon adsorbers. Examples of activities coming under increased regulation include paint shops, dry cleaning, solvent cleaning and degreasing operations, plastics processing, electronics manufacturing, chemicals and pharmaceutical manufacturing, printing and graphic arts industries, wood products and many more. Potential applications also exist for recovery of mercury vapor from fuel combustion and other mercury-bearing gas streams. Other volatilized metals (Se, As) from combustion processes may also be recoverable with activated carbon. 
Remedial actions at Superfund sites with organic chemical pollution of groundwaters frequently call for "pump and treat" processes. The treatment often involves air or hot gas stripping of the polluted groundwater followed by either thermal destruction or vapor recovery with activated carbon.

\subsection{United States Production of Activated Carbon}

United States production of activated carbon is on a general upward trend, with an average compound growth rate of $3 \%$ per year over the last 15 years (Figure 12).

Although many forecasters expect higher growth rates based on the growth rate since 1986, 3\% per year is the long-term historical record. Figure 12 and Table 13 show that total production is about evenly split between the granular (mostly gas-phase applications) and pulverized (liquid-phase applications) types. Imports and exports are both on the order of 20 million tons per year (Tables 14 and 15).

Shown in Figure 13 are the locations of major activated carbon producers. There are really only five large-scale producers in the U.S. Their approximate capacities in millions of pounds per year are:

Calgon

American Norit

Westraco

Atochem

Barnebey \& Sutcliffe

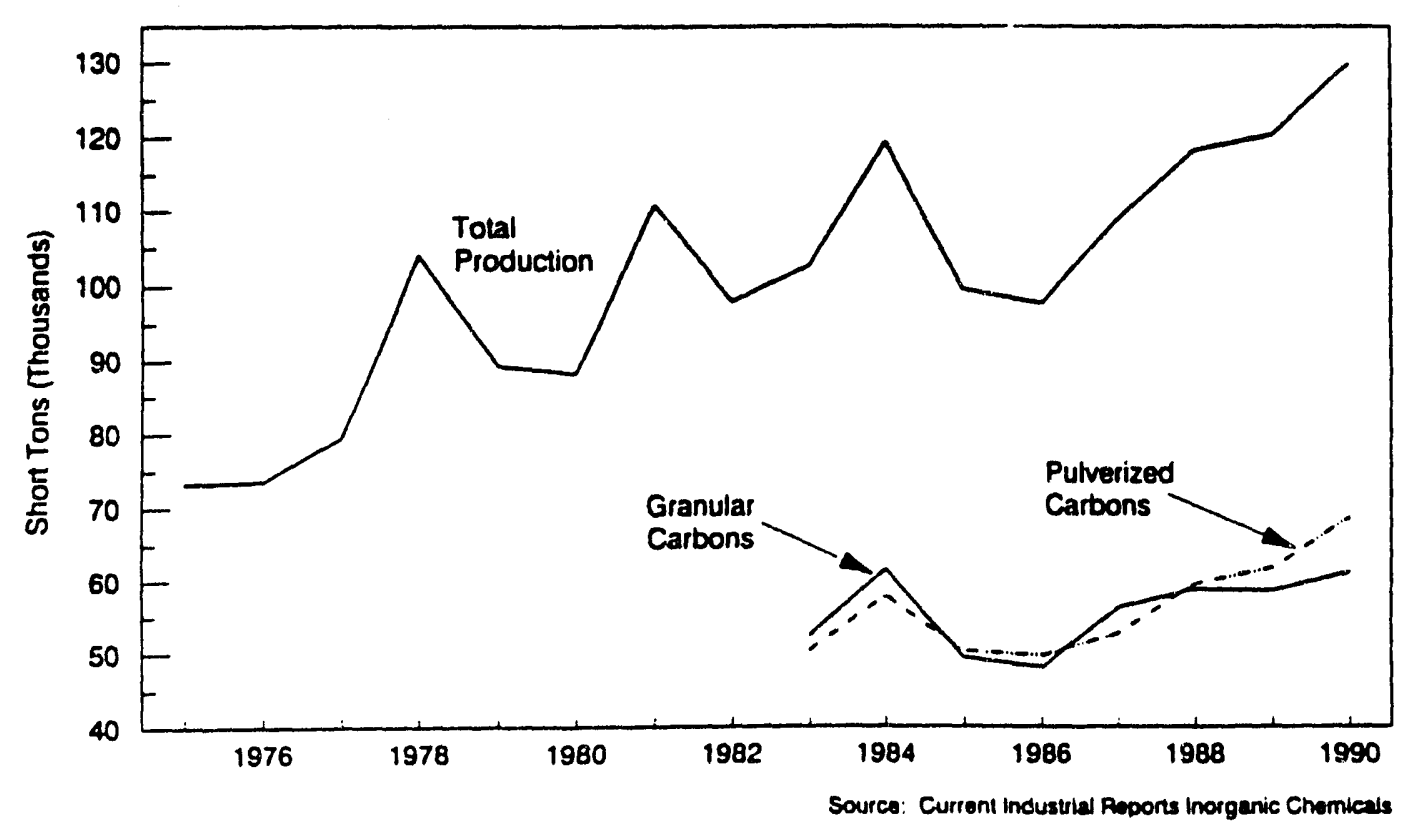

Figure 12. United States production of activated carbon products. 
TABLE 13

Production of Activated Carbon by Type

(Thousand Tons)

\begin{tabular}{cccr}
\hline Year & Granular Carbons & Powdered Carbons & Total \\
\hline 1981 & 52.6 & 58.2 & 110.8 \\
1982 & 48.4 & 49.5 & 97.9 \\
1983 & 50.2 & 52.3 & 102.5 \\
1984 & 57.8 & 61.5 & 119.3 \\
1985 & 50.2 & 49.3 & 99.5 \\
1986 & 49.6 & 48.0 & 97.6 \\
1987 & 52.6 & 56.2 & 108.8 \\
1988 & 59.5 & 58.7 & 118.2 \\
1989 & 61.7 & 58.5 & 120.2 \\
1990 & 68.6 & 61.1 & 129.7 \\
\hline
\end{tabular}

TABLE 14

U.S. Imports of Activated Carbon

\begin{tabular}{cc}
\hline Year & Thousand Tons \\
\hline 1980 & 7.9 \\
1981 & 7.3 \\
1982 & 5.7 \\
1983 & 3.7 \\
1984 & 11.8 \\
1985 & 11.2 \\
1986 & 8.6 \\
1987 & n.a. \\
1988 & n.a. \\
1989 & 21.5 \\
1990 & 21.4 \\
\hline
\end{tabular}

Sources: Current Industrial Reports Inorganic Chemicals (7) and Roskill, Economics of Activated Carbon, 1990 (8). 


\section{TABLE 15}

U.S. Exports of Activated Carbon

\begin{tabular}{ccc}
\hline Year & Quantity (Thousand Tons) & Value (\$ Million) \\
\hline 1982 & 14.1 & 18.7 \\
1983 & 13.5 & 19.3 \\
1984 & 15.0 & 18.6 \\
1985 & 29.4 & 19.2 \\
1986 & 15.9 & 20.5 \\
1987 & 17.8 & 23.7 \\
1988 & 17.3 & 29.1 \\
1989 & 20.1 & 34.0 \\
1990 & 23.0 & 37.7 \\
\hline
\end{tabular}

Sources: Current Industrial Reports Inorganic Chemicals (7) and Roskill, Economics of Activated Carbon, 1990 (8).

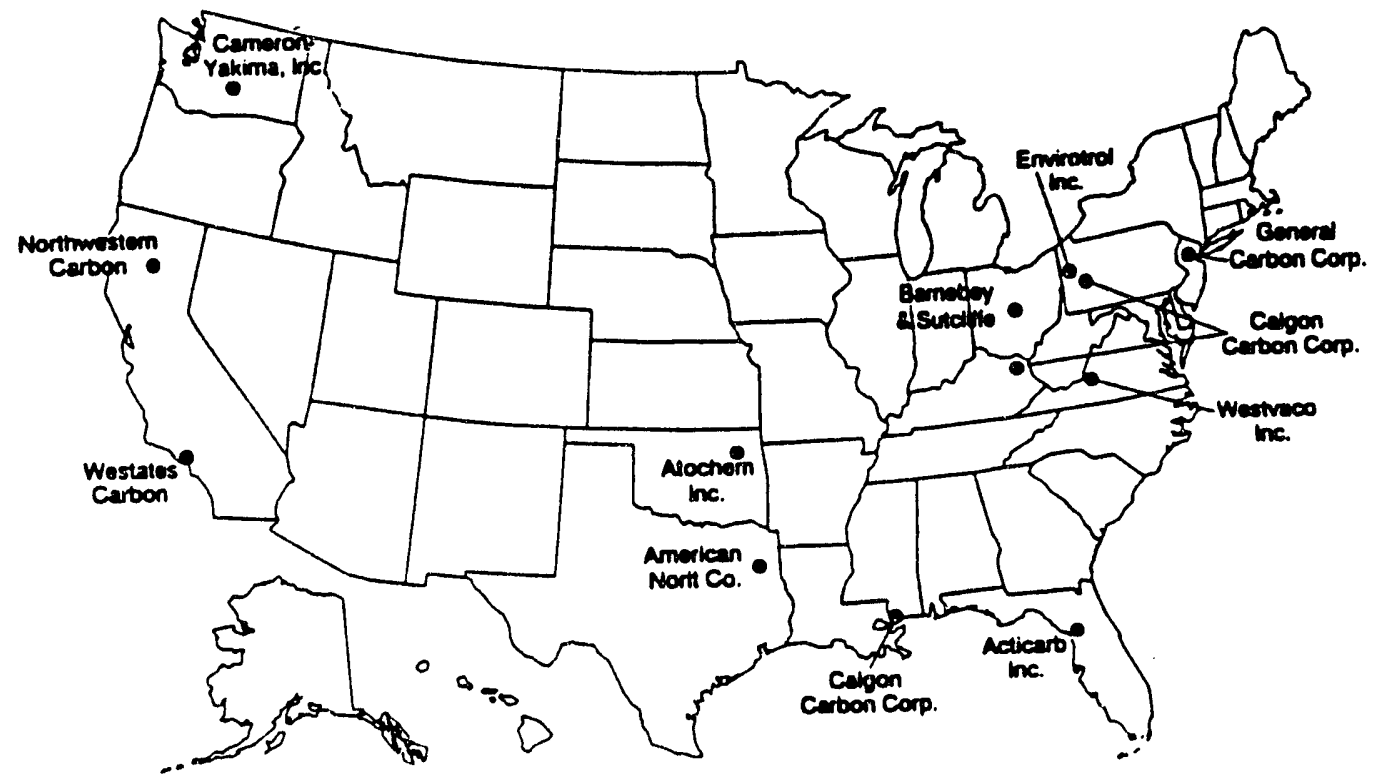

Figure 13. Activated carbon producers. 
Atochem has just completed expanding its coal-based production facilities at Pryor, Oklahoma, from 25 to 60 million pounds per year.

American Norit is expanding its Marshall, Texas, plant capacity by about 10 million pounds per year in early 1992. This expansion plus a second phase tentatively planned for 1994 would amount to 20 million pounds per year of new capacity.

Calgon Carbon restarted a formerly shutdown 18-million-pound-per-year facility in Catlettsburg, Kentucky, in 1990. Caigon built a new 30-million-pound-per-year plant at Pearlington, Mississippi, at the end of 1991. When this plant and the new American Norit plant come onstream, total U.S. production capacity will be well in excess (25\%) of current needs. However, demand for some specific types could be closer to being in balance with capacity.

\subsection{Prices}

Purification of drinking water and wastewater is the largest single use of activated carbon. Prices in the market are determined primarily on a bid basis. Prices for granular activated carbon at the low-price end of the range may be $\$ 0.25$ to $\$ 0.40$ per pound. At the high-price end of the range, specialty products may run $\$ 2.00$ per pound and more. Prices have been relatively unchanged over the last 10 years (Table 16).

\subsection{Outlook}

As noted in Figure 12, the long-term growth rate for activated carbon has been $3 \%$ per year. Different forecasters have suggested that future growth will be both above and below this trend. The strong activated carbon industry at the start of the 1990s contrasts significantly with the depressed market a decade before. A surplus supply of activated carbon in the early 1990 s led to a reduction in U.S. capacity from 180,000 tons per year to 125,000 tons per year between 1982 and 1986, and grades of activated carbon were sold at discounts of up to $20 \%$ off list prices.

The purification of municipal, potable, and groundwater will continue to lead growth in demand for activated carbon in the early 1990s. According to Roskill (8), an overall growth of 5\% per year in U.S. consumption will lead to an increase in demand of over 10,000 tons per year between 1991 and 1993. Demand for activated carbon in groundwater treatment alone is estimated to rise by $15 \%$ per year. Around one-half of the U.S. population relies on groundwater as a source of drinking water and a number of states have mandated the removal of volatile synthetic compounds which leak into the water supply through leachate from landfills and other sources.

A growth in demand of over $4 \%$ per year is also forecast for the use of activated carbon in gas purification, which accounts for nearly $15 \%$ of U.S. consumption. 


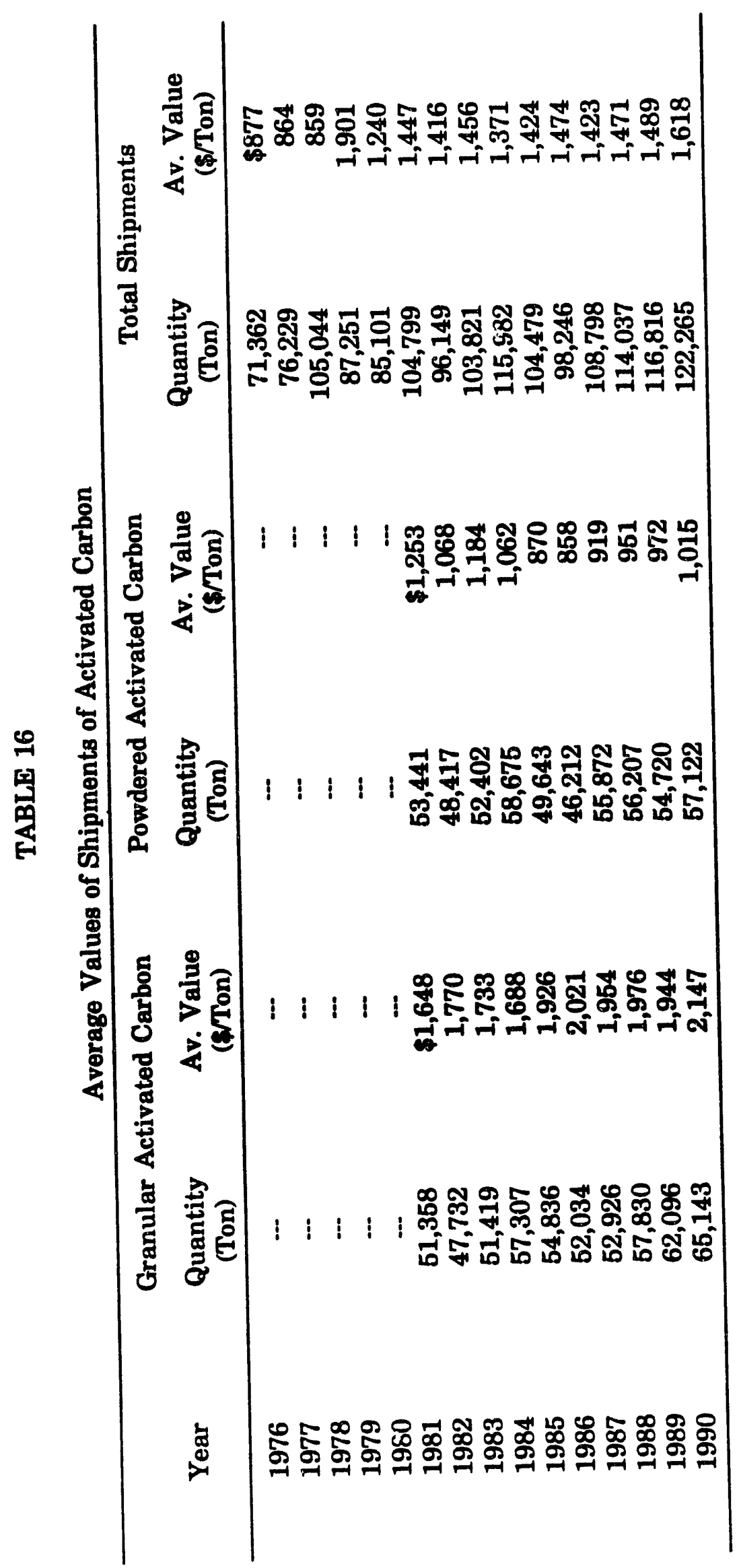


The activated carbon industry tends to suffer from cyclical demand because of the ability of granular grades to be regenerated. The high rate of growth in demand for water treatment in the early 1990s is unlikely to continue through 2000 as significantly lower quantities of carbon are needed to replace spent carbon than are used to bring a plant on stream. In order to prevent an excess supply leading to overproduction and low prices as occurred in the early 1980s, several producers are concentrating on expanding regeneration rather than new production capacity. One manufacturer that also runs a major reactivation center gave price ranges of $\$ 0.83$ to $\$ 1.27$ per pound for virgin carbons and $\$ 0.18$ to $\$ 1.17$ per pound for reactivated carbons.

A market survey of the activated carbon industry carried out in 1991 by Intech (9) asked activated carbon producers about their estimates of the current and future activated carbon markets.

The 17 companies surveyed manufacture and/or supply and distribute activated carbon or activated carbon systems to customers throughout the U.S. In terms of market share, all respondents except for one reported that "water purification" was the largest market, with this category including wastewater treatment, groundwater cleanup and remediation, drinking water purification, and surface water remediation. This market represented from $30 \%$ to $90 \%$ of the individual company's business, although not all of the respondents would give data due to proprietary considerations. Gas and toxic air emission treatment markets appeared to hold between $5 \%$ and $50 \%$ of the respondents' business. All respondents agreed that the markets for water treatment and gas treatment are growing faster now than the markets for other applications. This is attributed to the 1987 Clean Water Act requirements and to the 1990 CAAA. The general consensus was that activated carbon purity requirements in the food and pharmaceutical industries would severely limit the potential for use of coal-based products. No such limitations were envisioned for air emissions control, groundwater cleanup, or wastewater treatment, but it was felt that some limitations would exist for drinking water purification.

According to the study respondents, the activated carbon market growth is now estimated at 5\% to 7\% per year due to the new regulatory requirements for water and air. New activated carbon production capacities of 75 million pounds per year were identified to have been committed to construction at the time of the survey (about two-thirds of this will be based on coal-based carbon sources).

The midwestern states were judged to account for about $15 \%$ to $25 \%$ of the U.S. market. However, the CAAA of 1990 were felt to be particularly important in this region, and the Act's requirements for toxic air emission controls could cause the Midwest region to account for about $40 \%$ of the new U.S. market growth in the 1990 s.

Some suppliers commented that the greatest near-term potential for mild gasification chars to enter the activated carbon market would not be associated with new activated carbon applications, but to the ability to displace other coal-based feedstocks from existing activated carbon markets.

Survey respondents said, overwhelmingly, that pollution control and environmental cleanup, particularly water --eatment (remediation and purification) and toxic air emission control, would be the greatest growth areas for the market over the next 10 years. Air treatment, while considered as a great growth area, was believed to have a 
smaller potential market than water treatment. This is because the regulatory toxic air emission limits have not yet been set. It is not yet known if other processes which provide less control, but are less expensive, will be acceptable and thus displace activated carbon as the preferred control technology.

In addition to current environmental standards, some respondents mentioned the further increase in the market due to standards that will be forthcoming for indoor air quality, automobile emissions, and solvent emissions. It was suggested that it could take 3 to 5 years for the CAAA to fully impact the demand for activated carbon.

\subsection{Implications for Mild Gasification}

Mild gasification coal char can never capture the entire market for activated carbon because of the need for specific properties which are more readily obtainable from other sources. Because the cost of the carbonaceous feedstock is only a small percent of the total cost of manufacturing activated carbon, there is not a large enough economic incentive to use coal rather than other materials better suited to specific applications. The total U.S. market for activated carbon is only about 130,000 tons per year. The Midwest, where a majority of the carbon produced at an Indiana site might be expected to be sold, accounts for $15 \%$ to $25 \%$ of the total. Activated carbon made from mild gasification char would face competition from entrenched producers with existing excess production capacity. Unless a project were developed with one of those producers to replace existing production elsewhere, it would probably be difficult to find financing for an activated carbon project.

In conventional activated carbon production, about 2 pounds of coal are required to make about 1 pound of activated char. Thus, on a direct cost of coal basis, mild gasification char would have to sell for less than $\$ 80$ per ton to remain competitive with the coal feedstock. However, much of the cost of activating coal is incurred in carbonizing it. If the char were produced at lower cost due to economies of scale, and if the mild gasification coal tar could be used as the binder, then the combination of char/coal tar might remain competitive with conventional coal/pitch at prices up to $\$ 300$ per ton. 


\subsection{MILD GASIFICATION CHAR FOR CONTROL OF TOXIC EMISSIONS}

\subsection{Introduction}

The removal of trace quantities of mercury, dioxins, and other toxic substances from the stack gases of municipal waste combustors is a subject of ongoing concern to the public at large. A product derived from mild gasification char may be extremely effective in controlling these pollutants $(9,10)$. In Germany, a stack gas final filter that uses a mildly activated lignite char is being demonstrated and is expected to provide almost complete removal of these toxic materials. Two similar processes are being developed in Japan. In the United States, toxic emission control regulations are being developed for municipal waste combustors and may eventually be developed for electric power plants. If these regulations are based on maximum achievable control levels, a large market for char could develop.

\subsection{Pollution Control Regulations for Municipal Waste Combustors}

\subsubsection{New Rules Issued by EPA}

The Clean Air Act Amendments of 1990 established a new Section 129, which applies to municipal waste combustors (MWC), medical waste incinerators, infectious waste incinerators, and industrial waste incinerators. On February 11, 1991, the Environmental Protection Agency (EPA) announced new guidelines for large MWCs. The guidelines are to be reviewed in 1992, allowing for further additions or revisions. The review will include the addition of numerical emission limits for mercury, cadmium, and lead.

The standards are to be fully implemented by 1994 at 100 existing incinerator plants and will apply immediately to 30 new plants, with a total of 70 units expected to be built within the next 5 years. The standards also will apply to all future facilities. For new large combustors, the limit on dioxins (CDD) and furans (CDF) is $30 \mathrm{ng} / \mathrm{dscm}$ (nanograms per dry standard cubic meter).

The best demonstrated technology (required) for new large MWCs is defined as:

- Good combustion practices for organics control.

- A spray dryer absorber (SDA) followed by a fabric filter for $\mathrm{SO}_{2}$ and particulates.

- Selective noncatalytic reduction (SNCR) for $\mathrm{NO}_{\mathrm{z}}$ control.

- Any technology that meets guidelines.

For existing large combustors, the standard for dioxins and furans in large plants is $125 \mathrm{ng} / \mathrm{dscm}$, and for dioxins and furans in very large plants it is $60 \mathrm{ng} / \mathrm{dscm}$.

The best technology basis for existing MWCs is defined as:

- Good combustion practices.

- For large plants, dry sorbent injection plus ESP.

- For very large plants, spray dryer plus ESP. 


\subsubsection{Regulation of MWC Emissions by Local Jurisdictions}

The preceding section described federal standards for municipal waste combustors. Individual states which are required to prepare State Implementation Plans may not propose standards which are less strict. However, both states and smaller governmental jurisdictions may impose more stringent standards, and several have done so.

\subsection{The State of the Art for MWC Emission Control}

\subsubsection{System Descriptions}

Most existing MWC systems in the United States have control devices only for particulate matter (PM). Although a wide variety of PM control technologies have been demonstrated, EPA has selected two as qualifying for best demonstrated technology: the electrostatic precipitator (ESP) for existing plants, and the fabric filter (FF) for new plants.

Control of acid gases $\left(\mathrm{SO}_{2}\right.$ and $\left.\mathrm{HCl}\right)$ can be achieved by the injection of alkaline adsorbent (either as dry particles or as a water slurry) into the flue gas stream upstream of the $\mathrm{PM}$ removal device. The $\mathrm{SO}_{2}$ and $\mathrm{HCl}$ are rapidly adsorbed onto and react with the alkaline particles, which are then removed by the PM control device. Thus a complete PM plus acid gas control system consists of an alkali injection step plus a particulate removal step. The best demonstrated technology for alkali injection is a spray dryer adsorber. The PM control device could be either an electrostatic precipitator or a fabric filter, depending on the application.

\subsubsection{Pollution Control Performance}

Studies carried out for the EPA (11) conclude that a spray dryer plus fabric filter would give long-term emission reductions of $97 \%$ for $\mathrm{HCl}, 90 \%$ for $\mathrm{SO}_{2}$, and $99 \%$ for $\mathrm{CDD} / \mathrm{CDF}$ with a maximum CDD/CDF outlet concentration of $5 \mathrm{ng} / \mathrm{dscm}$.

Most of the performance data are limited to acid gas control with only limited $C D D / C D F$ data available. Only a small number of MWCs have been tested for CDD/CDF emissions, and these data are highly variable. Removal of mercury and heavy metals occurs by condensation onto the particulate matter. The efficiency of this process for mercury depends greatly on the temperatures achieved and, therefore, varies widely from one system to another. Figure 14 shows the range of mercury removal efficiencies tabulated by the Electric Power Research Institute for different flue gas control systems on power plants.

\subsection{The Activated Char Filtration System}

\subsubsection{System Descriptions}

There are three activated carbon acid gas scrubbers currently being developed: the Stadtwerke Düsseldorf process; the Bergbau-Forschung/Mitsui process; and the Sumitomo process. All of the processes are based on the fact that most flue gases contain enough oxygen, water vapor, and sulfur dioxide to support the following reactions: 
- The activated carbon acts as a catalyst to oxidize the sulfur dioxide to trioxide.

- The activated carbon also supports the hydration of the trioxide with the water vapor to form sulfuric acid. The sulfuric acid is held on the carbon surface in the carbon's small pores.

- Ammonia is injected into the flue gas for $\mathrm{NO}_{2}$ control. The activated carbon catalyzes the reaction between ammonia and $\mathrm{NO}_{\mathrm{z}}$ to form water and nitrogen.

In addition to its catalytic function, the activated carbon is an efficient sorbent for toxic air pollutants, including heavy metals, volatile organics, and products of incomplete combustion. This attribute may make it a preferred sorbent for the control of hazardous air pollutants.

In Germany, an advanced flue gas treatment system has breen developed by Stadtwerke Düsseldorf AG for its power plants and waste incinerators. It consists of a spray dryer plus a particulate removal system, which is then followed by a filtration/adsorption bed containing coke or activated char derived from lignite. This bed serves as a polishing step, removing almost all traces of $\mathrm{SO}_{2}, \mathrm{HCl}$, dioxins, furans, mercury $(\mathrm{Hg})$, and other heavy metals.

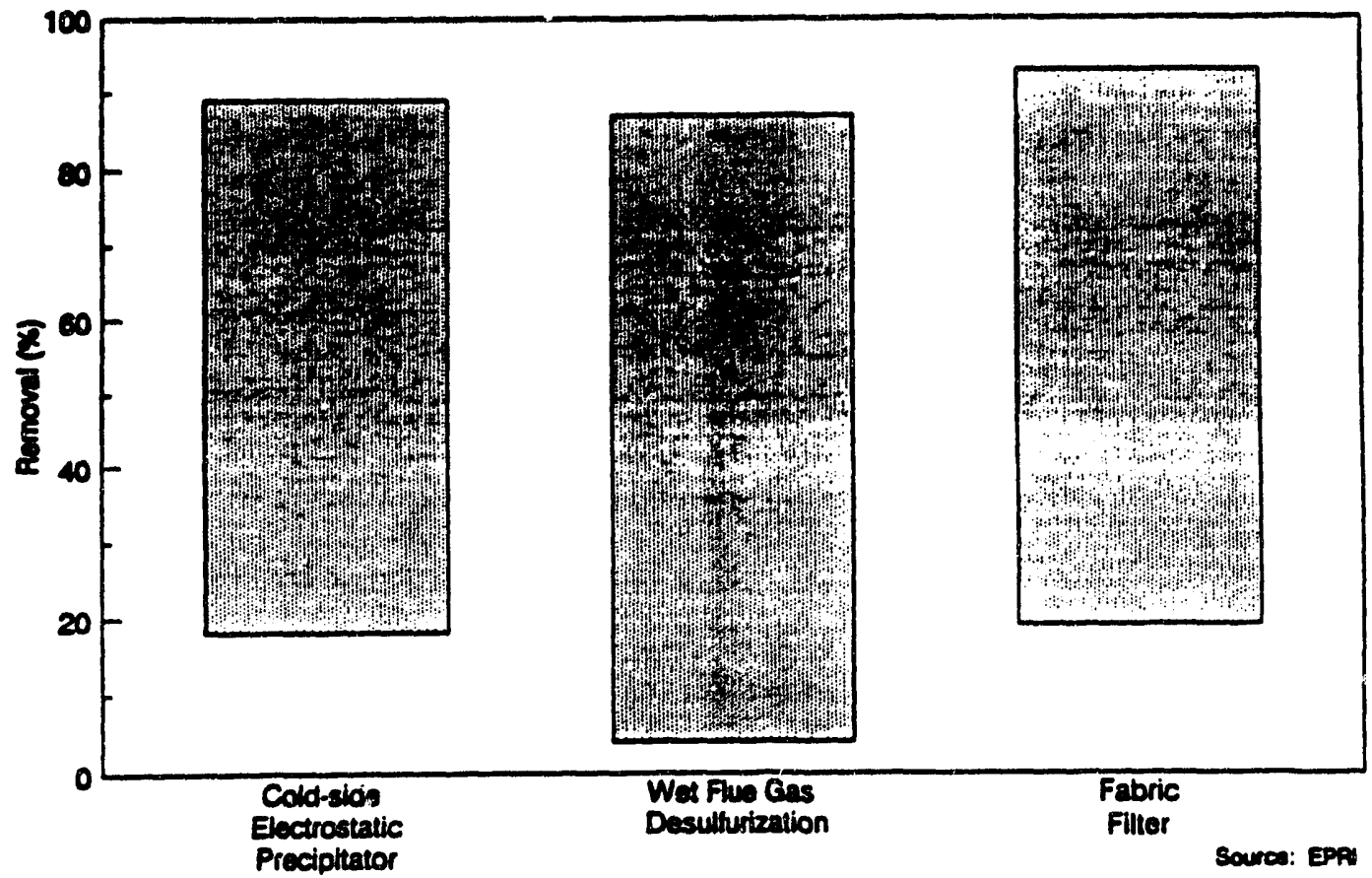

Figure 14. Mercury removal by emission control devices. 
A schematic of the "Diisseldorf system" is shown in Figure 15. This system includes a primary electrostatic precipitator (not required in all cases) followed by a lime-injection spray dryer, a second ESP, then the coke filtration step. As noted in Figure 15, the char, once loaded with $\mathrm{SO}_{2}, \mathrm{HCl}$, heavy hy trocarbons, and heavy metals, is sent to the combustor and burned. The heavy hydrocarbons will be mostly destroyed, and the other materials will mostly be adsorbed in the spray dryer on their second pass through the system.

Not shown in Figure 15 are details of the lignite coke recycling system to account for mercury removal which may be necessary for MWC plants. The treatment for mercury will depend on the acid gas scrubbing system used. If a wet scrubber is used, the temperatures will be low enough to condense almost all mercury in the scrubber, and there will be no buildup of mercury in the system if the mercury-laden coke is recycled to the combustor.

On the other hand, if dry or semidry acid gas removal systems are used, the scrubber exit temperatures may be high enough to allow most of the mercury to pass through, and a gradual buildup of mercury in the system could result. The solution, indicated in Figure 15, is to divert the first fraction of the coke bed (where the mercury is heavily concentrated) to a separate toxic treatment step. The front part of the coke bed, laden with mercury, can be desorbed by heating to $400^{\circ} \mathrm{C}$ in the absence of air. Dioxins are decomposed at this temperature. Mercury is driven off and may be captured in a water quench condenser.

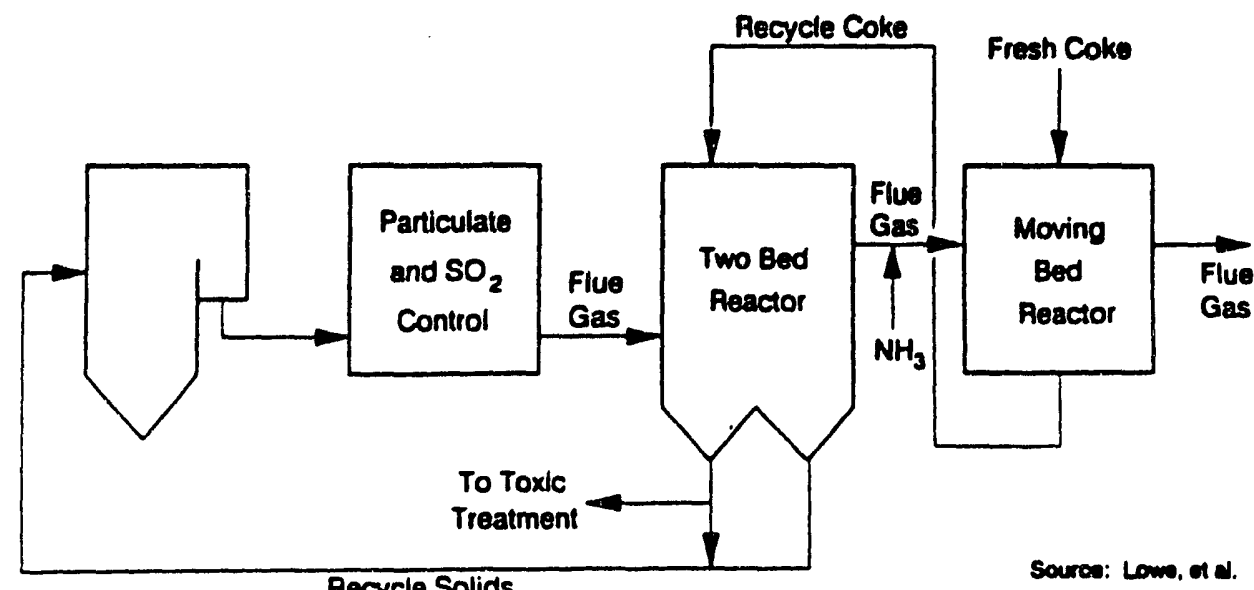

Figure 15. Stadtwerke Düsseldorf activated carbon scrubber. 
The first lignite coke-based flue gas treatment systems downstream of municipal waste combustors in Germany were scheduled for start-up in 1991.

The Bergbau-Forschung/Mitsui process is being developed in Germany and Japan. However, most of the commercial development has been under the direction of Mitsui in Japan. In this process, the flue gas is first cleaned of particulates, humidified, and cooled to the activated carbon operating temperature. A two-stage reactor is used. The flue gas first enters the second stage where $\mathrm{SO}_{2}$ is absorbed as $\mathrm{H}_{2} \mathrm{SO}_{4}$. Ammonia is added to the flue gas which then enters the first stage for $\mathrm{NO}_{\mathrm{z}}$ reduction. Fresh activated carbon or coke is introduced in the top of the first stage. The activated carbon moves downward into the second stage where $\mathrm{SO}_{2}$, trace elements, and halogens are adsorbed. From there, the carbon is moved to a desorption reactor where it is heated with the exhaust gas from a burner. After the activated carbon has been regenerated, it is cooled, makeup carbon is added, and the mixture is returned to the two-stage reactor. The regeneration step offgas must be processed for sulfur or acid recovery. Over $98 \% \mathrm{SO}_{2}$ and $80 \% \mathrm{NO}_{x}$ removal have been reported. The process is in commercial use at a refinery in Japan.

In the Sumitomo process, ammonia is added to the flue gas, and the resulting flue gas is then sent to a single adsorber unit. The adsorber is a moving-bed reactor of activated carbon. Part of the ammonia forms bisulfates which deposit on the carbon and part of it reduces $\mathrm{NO}_{2}$ to nitrogen and water. Any $\mathrm{SO}_{2}$ is converted to $\mathrm{H}_{2} \mathrm{SO}_{4}$ which is adsorbed on the carbon. The spent carbon is removed from the adsorber and heated to the regeneration temperature of $570^{\circ}$ to $750^{\circ} \mathrm{F}$ which releases the adsorbed materials. The regenerated carbon is then cooled, makeup activated carbon is added, and the mixture is returned to the adsorber. The bisulfates on the spent carbon reduce the formation of $\mathrm{CO}_{2}$ during the regeneration process. This controls the carbon consumption to $0.5 \%$ to $1 \%$ per day. $\mathrm{NO}_{\mathrm{z}}$ reductions are $20 \%$ to $40 \%$ (30\% average), and $\mathrm{SO}_{2}$ reductions are $90 \%$ to $95 \%$ average. Because both ammonia and carbon consumption increase with increasing $\mathrm{SO}_{2}$ concentration, the process has been limited to $1 \%$ or less sulfur fuel applications. The process is in commercial use at an iron-ore sintering facility in Japan.

\subsubsection{Pollution Control Performance}

Operating data are not yet available from actual commercial installations of the char filtration process on municipal waste combustion systems. However, data are available from laboratory, pilot plant, and demonstration plant tests. In these tests, high separation efficiencies were proven for a large number of pollutants. These include all $\mathrm{SO}_{2}, \mathrm{HCl}, \mathrm{NH}_{3}$, basic amines, and gaseous heavy metals (mainly $\mathrm{Hg}$ ). Fine dusts and, hence, the adhering pollutants such as $\mathrm{Cd}$ and $\mathrm{Pb}$ are also filtered. There is excellent retention of organic compounds such as dioxins and furans which are of major concern in waste incineration plants.

In tests made for Stadtwerke Düsseldorf $A G$, it was demonstrated that:

- Sulfur dioxide is separated to almost zero levels.

- Hydrogen chloride is displaced further into the bed by $\mathrm{SO}_{2}$, but with a properly sized bed, the outlet $\mathrm{HCl}$ concentration is near zero. 
- Mercury is adsorbed strongly with an outlet concentration below the detection limit of 2 micrograms per cubic meter.

- The total concentration of dioxins and furans in the gas stream is reduced by a factor of 100.

- The particulate matter concentration (basically coke fines) leaving the coke bed is less than 10 milligrams per cubic meter.

- After passing through a coke bed depth of 1.5 meters, almost all pollutants have been separated.

To illustrate the benefits of the char filtration system as a final pollution control device, performance data are presented graphically in Figure 16. The addition of a lignite char filtration system dramatically reduces the levels of all pollutants in the stack gas.

\subsection{Comparative Economics for Char Filtration System}

\subsubsection{Pollution Control Costs}

Literature references regarding experience in Germany state that the char requirement is about 1 ton per 500 tons of municipal waste combusted. System cost data are given by Kassebohm (12). He estimates the incremental capital cost for a module treating the flue gas from a new 800-ton-per-day MWC plant to be approximately $\$ 14$ million. He states that the cost for a retrofit application would be about $20 \%$ higher or $\$ 16.8$ million.

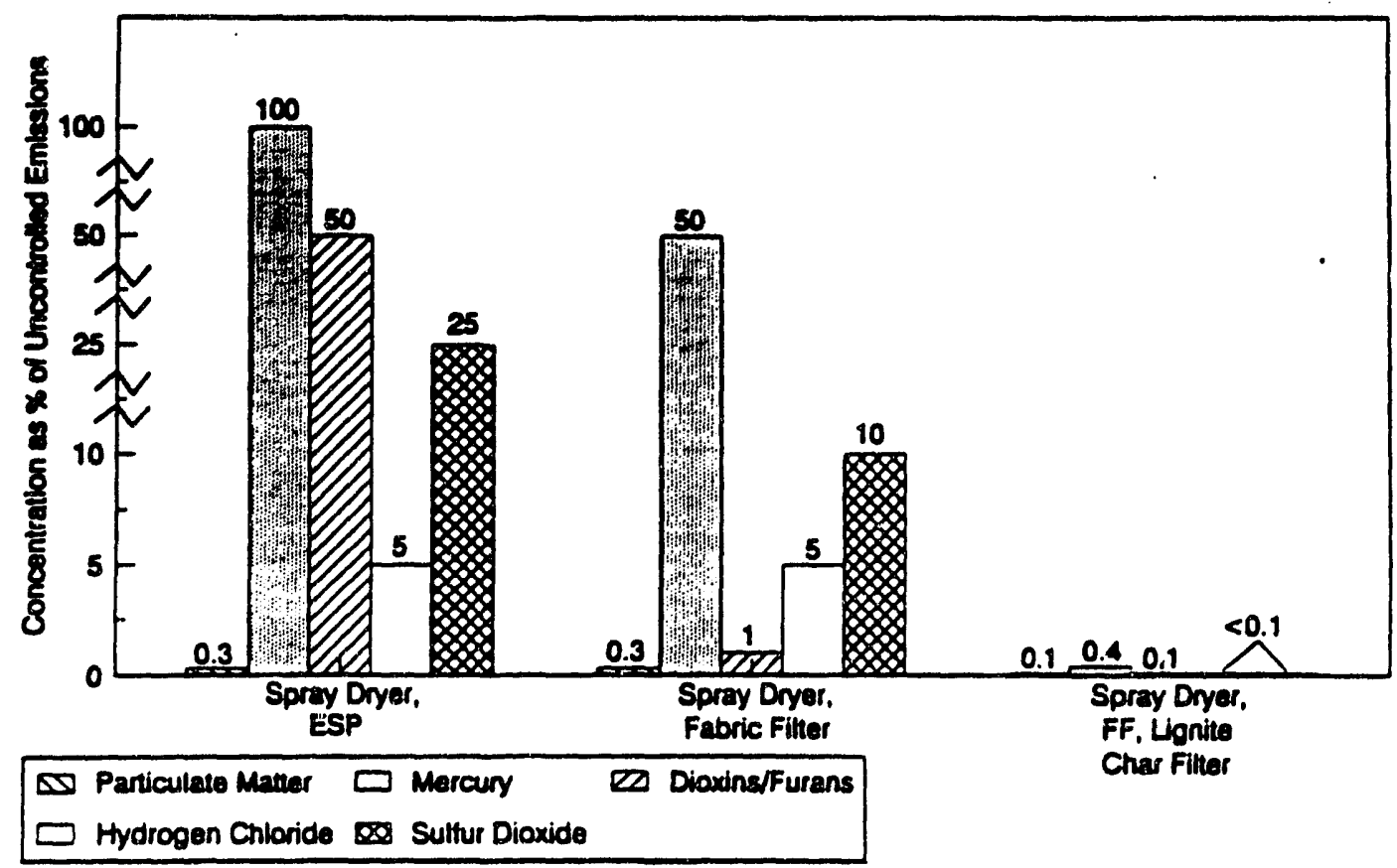

Figure 16. Estimated concentrations of pollutants in flue gas for different control technologies. 
For a total pollution control system consisting of spray dryer absorber (for sulfur dioxide and chlorides control), fabric filter (for particulate control), char filter (for mercury and dioxin control), and selective catalytic reduction (for nitrogen oxides control), the cost of char (at $\$ 150$ per ton) for the char filter accounts for less than $1 \%$ of the total yearly capital and operating cost at all plant sizes calculated. The cost of the char would amount to about $2 \%$ of the yearly operating costs exclusive of capital recovery. It may be concluded that, under these conditions, the cost of making the activated char should not be a major factor limiting the ultimate acreptance or rejection of the char filtration technology.

A potential contributing factor to process profitability in the United States is the sale of $\mathrm{SO}_{2}$ emission allowances. If the plant using char filtration is one that falls under the jurisdiction of the acid rain control program, it will be able to claim credit for reducing $\mathrm{SO}_{2}$ emissions below the required levels. Char will absorb about $5 \%$ by weight of $\mathrm{SO}_{2}$. At an estimated market value of $\$ 1000$ per ton of $\mathrm{SO}_{2}$ not emitted, a char filter user could obtain a benefit of $\$ 50$ per ton of char, should he choose to sell his allowances and rely on $\mathrm{SO}_{2}$ removal by the char.

\subsection{Market Evaluation}

\subsubsection{Unit Reauirements}

According to data presented in EPA background reports, there were 160 municipal waste combustors in operation in the United States in 1989 (11). More are expected to be built at the rate of five or six per year. In summary, the major opportunity for MWC emission control systems will be with mass burn combustors and secondarily with refuse-derived fuel combustors. This is because such units account for the largest share of total capacity (Figure 17). There is no indication that any particular type of MWC is more or less suited for application of char filtration technology.

The estimated future disposition of solid wastes in the United States (13) is shown in Figure 18. A major driving force for increased use of municipal waste combustion is the phasing out of landfill operations all around the country. One estimate is that one-half of the some 6000 landfills currently in operation will be shut down or closed within the neat 5 years. The average cost of dumping at landfills has increased severalfold in the last 15 years.

Of the total flow to municipal waste combustors shown in Figure 18, a small fraction (less than 8\%) goes to small units not subject to the emission control guidelines.

Therefure, the planning point for the year 1996 is approximately 45 million tons per year of municipal solid waste sent to combustors subject to emission guidelines.

\subsubsection{Market Development Factors}

The projections for increasing municipal solid waste flows combined with decreasing landfill capacity (Figure 18) would seem to indicate an assured strong market growth for municipal waste combustion. A waste-to-energy plant seems ideal to many city managers. Difficult-to-dispose-of garbage is converted to an income stream (electricity). However, there are some serious opposing factors. 


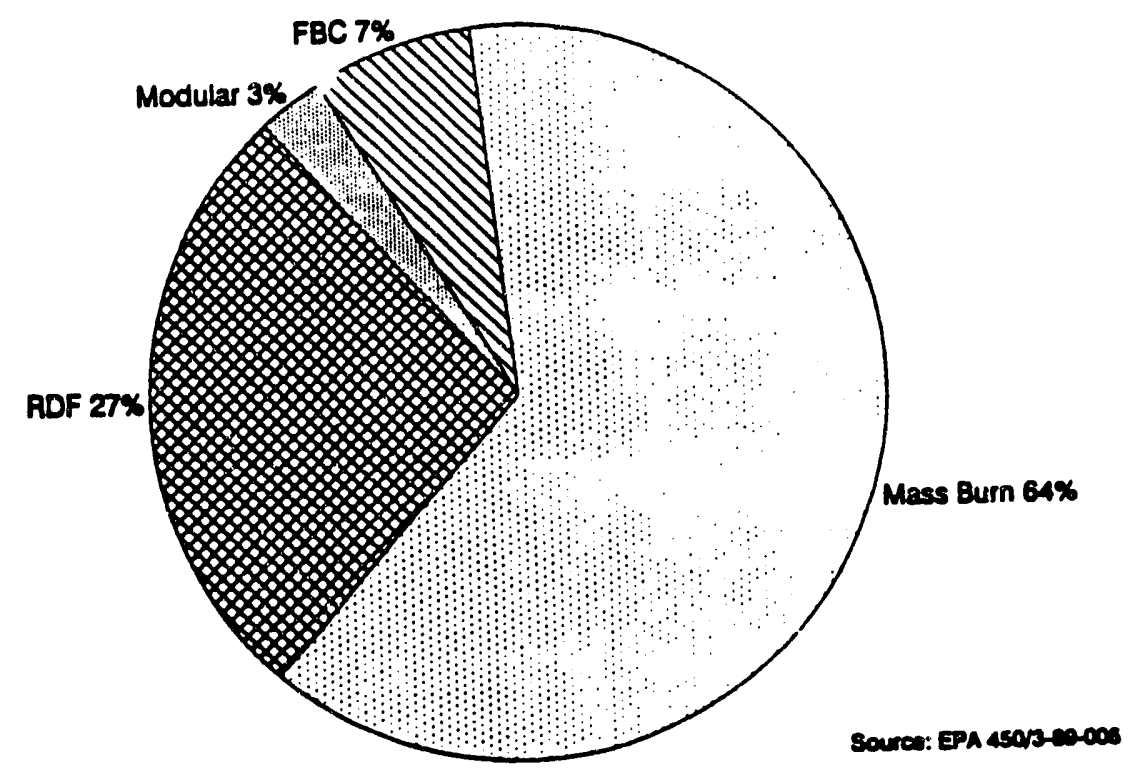

Figure 17. Projected technologies to be used in MWC plants subject to NSPS by 1994.

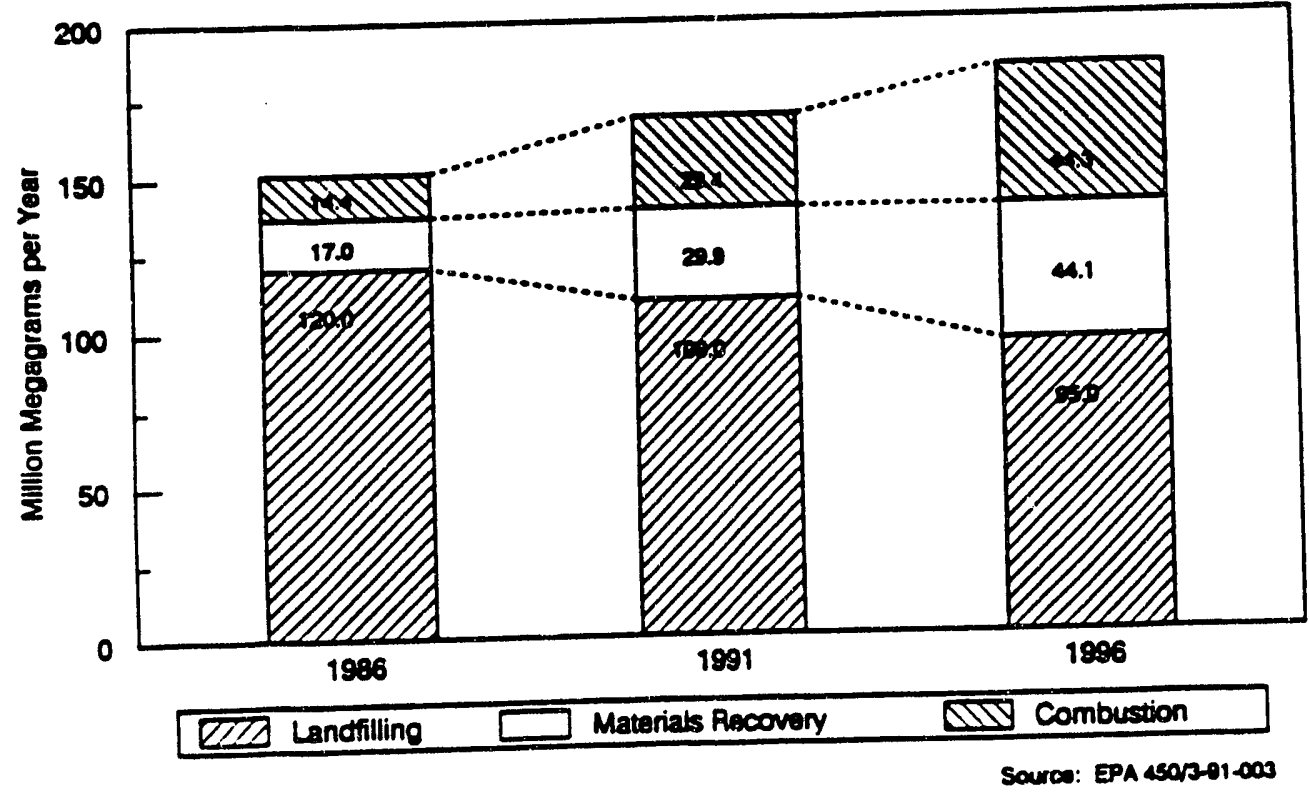

Figure 18. Solid waste flow projections. 
Of the three waste disposal options (landfill, incineration, recycling), combustion is probably the one that creates the greatest controversy. It may be that the visible large exhaust stacks are responsible for the very negative reaction which appears in most communities where MWC is proposed. Public opposition has resulted in the cancellation of many proposed projects where MWC appeared to be the most economic solution.

Approximately $80 \%$ of the typical municipal solid waste stream could be either incinerated or recycled. Recycling enjoys a much higher level of public acceptance. The projection in Figure 18 assumes that combustion will capture slightly more of the market than recycling. This is simply because most experts seem to feel that recycling more than $25 \%$ on a national basis is unrealistic. However, there has been discussion about EPA raising its goal from $25 \%$ to $40 \%$. Future developments in recycling will probably be the most important single factor affecting the MWC market. The projection in Figure 18 represents a reasonable consensus for the most likely case.

\subsubsection{Potential Char Requirements}

Because there is currently no regulatory requirement that MWC systems meet the emission limits achievable with the char filtration process, it is difficult to make a market projection. However, as people and organizations become aware of the potential benefits of the technology, it is likely to become a mandated addition to MWC emission control systems. An upper limit on the market for char can be derived by considering that all large combustors, processing $\mathbf{4 5}$ million tons of waste per year, would eventually install a char filter.

The amount of char required obviously depends on a large number of factors, such as:

- Characteristics of waste being combusted.

- Characteristics of the waste combustor.

- Efficiency of acid gas control system.

- Efficiency of particulate control system.

- Design of char filter system.

- Characteristics of the specific lignite char.

As a preliminary overall guideline based on the experience with German lignite char, it was estimated that a refuse throughput of 500,000 tons per year would require only 1000 tons of char per year. Thus, based on Figure 18, an upper bound would be 90,000 tons of char per year for 1996. However, test data obtained by the Energy and Environmental Research Center (14) suggest that for North Dakota lignite a ratio of 1 ton of char per 80 tons of waste might be more representative, yielding an upper limit of 560,000 tons of char per year. That would require a daily production capacity of approximately 1800 tons. Equivalent data on Indiana coal char have not been obtained.

The cost of lignite char in Germany is quoted in the literature as approximately DM250 per ton. This would translate to approximately US\$140 per ton.

If the technology should eventually become mandated for use on power plant stacks, demand could be even larger. A study recently released by the Center for Clean Air Policy, a nonprofit research group, concludes that because EPA has already acted to 
reduce mercury emissions from various sources, coal burning power plants will be the largest remaining source of mercury pollution in most states by the year 2000. The report maintains that growing evidence of accumulation of mercury in fish, particularly in the Great Lakes region, poses threats to wildlife and human health that could justify EPA regulations of mercury emissions from utilities. The quantity of mercury emitted from coal-fired power plants is less per million Btu of fuel than from municipal waste combustors, but, of course, the quantities of fuel consumed are much larger. Because the amount of mercury in coal is highly variable, there is no general rule to calculate the amount of mercury emitted and, therefore, the amount of char that would be required for control. EPRI has estimated (15) that the average uncontrolled emission of mercury from coal-burning power plants would be about 1 pound of mercury per MW per year. There are about 300,000 MW of coal-fired electric-generating capacity in the United States.

From Figure 14, it may be estimated that about $60 \%$ percent of mercury in the stack gas will be removed by other pollution control systems, leaving about 0.4 pounds per MW currently uncontrolled. If the char capacity for mercury is 100 parts per million, then it would require 600,000 tons of char per year for mercury absorption from all power plants.

\subsubsection{Competition Analysis}

There are a number of different technological approaches which appear to be capable of achieving performance equivalent to that of the char filtration system for any one pollutant. For example, mercury removal can be accomplished by adsorption on selenium-impregnated porous granules or on sulfated activated carbon. However, there seems to be no single commercially known tochnology which can reduce the full range of pollutants to the same level for the same cost as can be achieved by char filtration.

Joy/Niro have tested an alternative approach, in which they injected activated carbon along with lime in a spray dryer. The activated carbon adsorbs pollutants such as mercury and dioxins, giving considerably enhanced performance over that of the spray dryer alone. Although the mercury and dioxin removal efficiency have been considerably enhanced, the efficiency is still much less than can be achieved with the char filtration technique.

Although other adsorbents are known which are as effective as activated coal char, they all tend to be more expensive. A variety of manufactured adsorbents have been tested. These include such things as vermiculite coated with magnesium oxide, but none appears to be strong contenders on price. On an economic basis, therefore, activated char would appear to have an excellent competitive position when both dioxin and mercury control are required. The economic attractiveness can be enhanced by the fuel value of the char when it is burned. However, another major advantage of sending loaded char to the combustor is that this destroys the organics and diverts the mercury to the solid waste streams, avoiding the cost of hazardous material disposal, which is likely to be encountered by competing adsorbents.

\subsection{Implications for Mild Gasification}

The use of activated coal char for control of mercury and dioxins at municipal waste combustors represents a large potential market. It is certain that regulations for these pollutants will be developed, because they are required under the Clean Air Act 
Amendments of 1990 . It is not yet certain what the allowable emission levels will be. Therefore, it is uncertain what the actual market potential will be. However, the trends of the last 20 years have been toward tighter controls and toward requiring the best available technology. Once the effectiveness of char is demonstrated, at reasonable cost, there is a good probability of its being required.

The technology has been demonstrated on a commercial scale in Germany, using lignite char. It is unknown whether a mild gasification char produced from Indiana coal could give equivalent performance.

The potential for use at coal-burning power plants is much more speculative, but still a distinct possibility because of the public's continuing unwillingness to accept economic limits on pollution control. The Electric Power Research Institute and others are actively researching the mercury and air toxics problem and should be encouraged to study mild gasification char as one of the primary options. Under the new Clean Air Act, the EPA is required to carry out a 4-year study of mercury emissions from electric utility steam-generating units. Any new regulations will be set on the basis of that study combined with a parallel study at the National Institute of Environmental Health Sciences on the threshold level of mercury exposure to protect human health. Thus actual implementation of mercury control at power plants is not likely until afer the year 2000.

No technology is likely to capture $100 \%$ of any market, although the unique qualities of coal char for mercury and other air torics control suggest that it could be the first choice. If $25 \%$ of the theoretical maximum is used, this amounts to 150,000 tons of char per year by the year 2000 for control at municipal waste combustors and another 150,000 tons per year post-2000 for control at electric power plants. The probability of realizing the latter is not large at this point. 


\subsection{LIQUID PRODUCTS}

The final process design developed by Xytel-Bechtel has no liquid product stream. All the liquids produced during mild gasification are either used as binder in the formcoke process or are burned as fuel to generate electricity. However, a plant optimization study might show the desirability of selling instead of burning those liquids now going to the FBC unit. Also, a redesign based on a different coal might yield a different liquids balance. Finally, it is conceivable that an inexpensive coke binder might be found, making it profitable to sell the process tars instead of using them as binder. For all of these reasons, the 1988 market assessment of liquids was partially updated.

\subsection{The Coal/Oil Differential}

Because there is no application where coal and oil compete in which coal would be preferable to oil at the same price per Btu, coal will take market share from oil only if it is available at a substantially lower price. Another way of looking at the situation is that converting either the form of coal (so that it can be used in oil-fueled equipment) or the form of equipment (so that it can use coal instead of oil) requires a differential between coal and oil prices. If oil is lower-priced, no substitution will occur. Even when oil is higher-priced, the coal/oil differential (COD) must be large enough to make some conversions feasible. At the time of the 1988 market assessment, the COD had been plunging downward.

The recent history of the coal/oil differential is plotted in Figure 19. When the COD is positive, it indicates the amount of cash flow per Btu of fuel consumed which can be devoted either to manufacturing coal fuels with improved qualities or to direct coal utilization. During the period from the 1930s to 1950, the COD was negative, and this

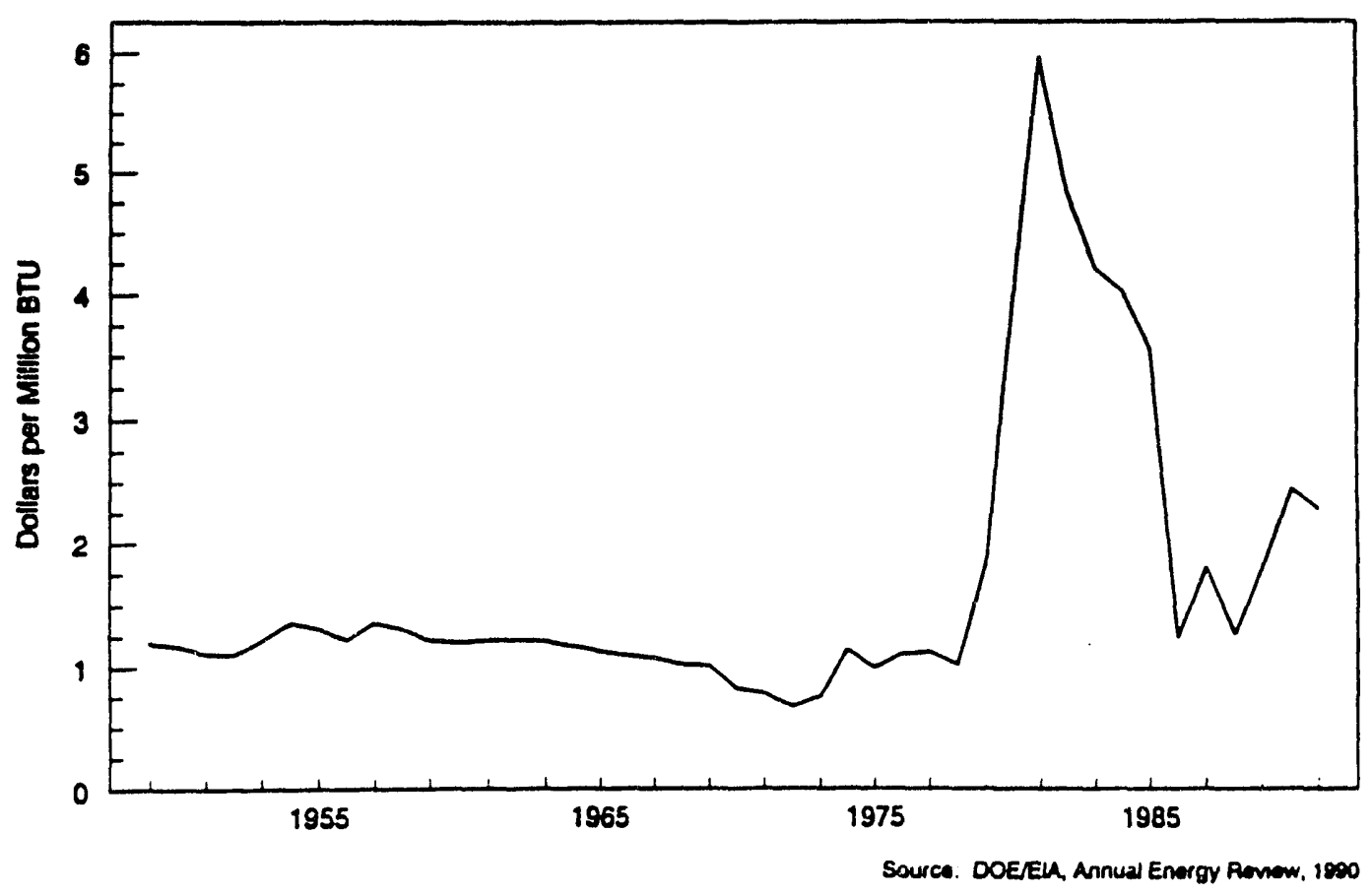

Figure 19. Coal/crude oil discount factor. 
period saw a massive substitution of oil for coal in applications such as railroad locomotives.

Only after 1970 did the COD show a great increase, sparking widespread interest and activity in synthetic fuels from coal. Viewed from this perspective, the drop in oil prices from 1981 to 1987 only returned the COD to its historical range. Since then, the COD appears to have bottomed out, but is still at far too low a value to make conversion attractive.

\subsection{Liquid Transportation Fuels}

\subsubsection{Refining Coal Liquids}

In a very broad sense, the liquid products from mild gasification could be expected to have properties ranging between those of liquids obtained by direct hydroliquefaction and those of liquids obtained by high-temperature carbonization in by-product coke ovens.

Any coal liquids can be converted to acceptable liquid fuels for the transportation sector by hydrotreating and hydrocracking processes. Extensive studies in the last 15 years have been unable to reduce the cost of hydrorefining processes to economically feasible levels. As a result, the once-ertensive development effort to produce liquid fuels by the direct liquefaction of coals in the United States had been almost totally abandoned by 1988 , and no change has occurred since.

In the past, coal-derived liquids were considered good gasoline feedstock because the high aromatic content resulted in a high-octane motor fuel. However, the Clean Air Act Amendments of 1990 are forcing refiners to reduce the aromatic levels in gasoline, making coal-derived liquids much less desirable than in the past.

\subsubsection{Diesel Fuels}

The 1988 market assessment noted that gasoline for spark-ignition engines in automobiles and trucks consists entirely of light products and could be produced from coal liquids only by severe upgrading. The lighter middle distillates such as jet fuel and No. 1 diesel fuel are less highly refined products, but are still produced to tight specifications. Therefore, the prime market opportunity for minimally treated mild gasification liquids must lie in the heavier fuel grades.

Railroad diesels were determined to represent an intermediate opportunity which may not require the expensive upgrading necessary to make automotive diesel, but which may be able to substitute some coal liquids for a premium (above the value of No. 6 oil) fuel. Mild gasification liquids have, in fact, been tested in a locomotive diesel engine. See the 1988 report for a complete discussion of fuel specifications.

Railroad demand for diesel fuel is relatively constant (Figure 20). The demand within a 500-mile radius of the Chinook mine, Indiana, was estimated at over 82,000 barrels per day in 1988 and should be approximately the same now. Thus the output of coal liquids from a 1000-ton-per-day coal gasification plant would be completely insignificant and could be blended into better quality material. The variation in prices over the last few years is shown in Figure 21. 


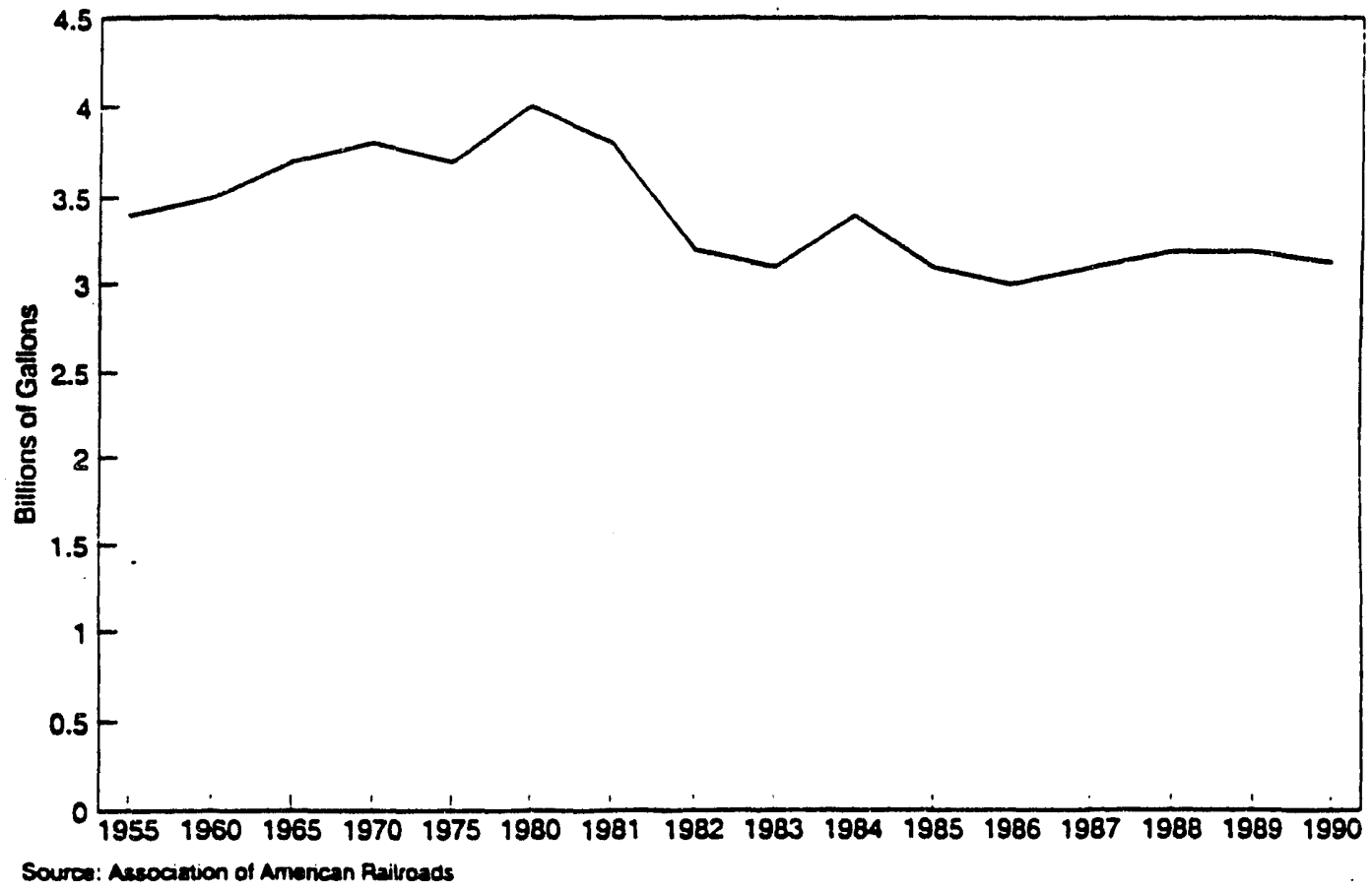

Figure 20. Locomotive diesel fuel consumption.

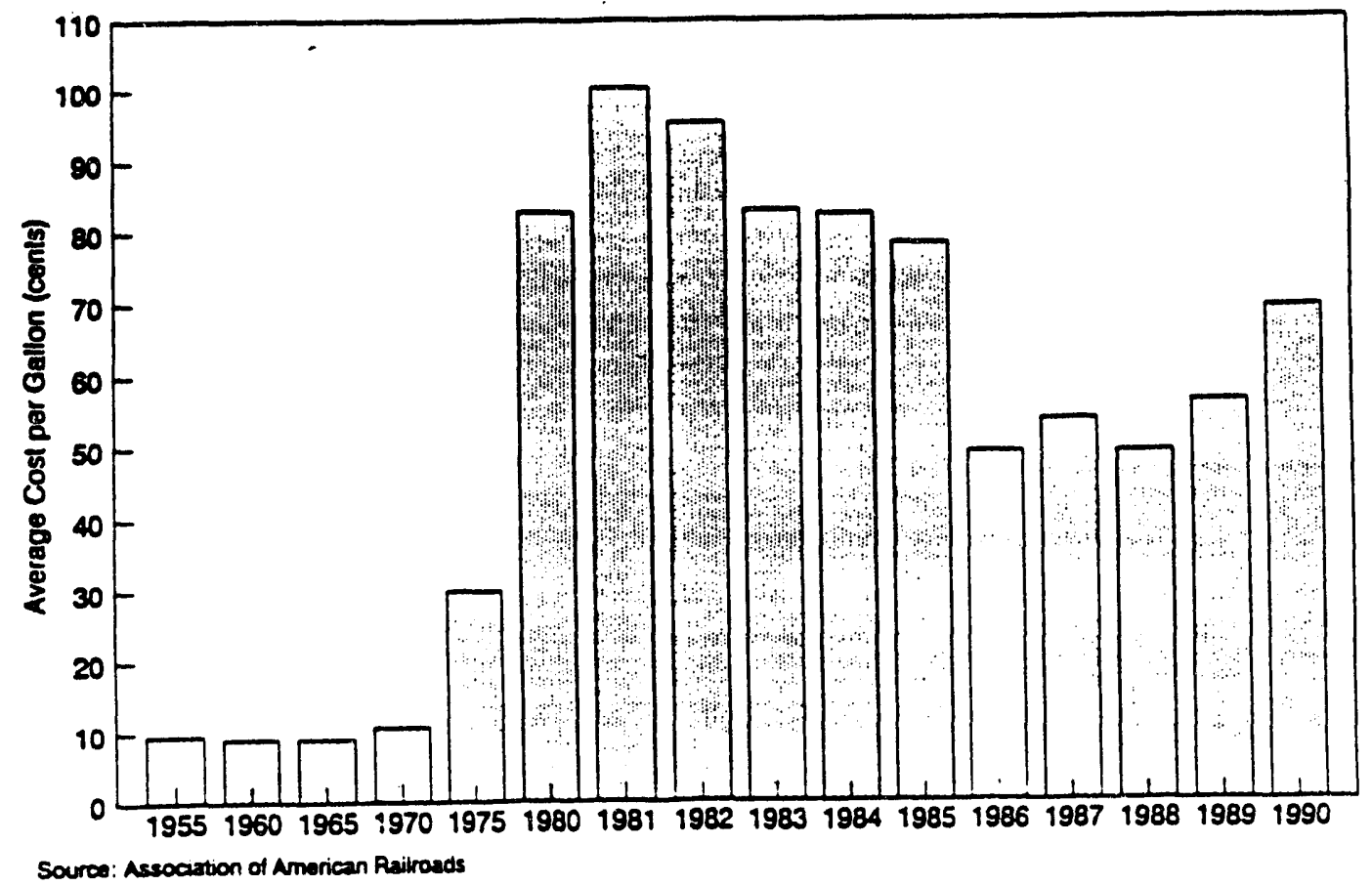

Figure 21. Locomotive diesel fuel cost. 
The biggest change which has occurred since 1988 is the passage of the Clean Air Act Amendments of 1990 . Emissions from railroad locomotives will likely end up being regulated by the Environmental Protection Agency. This will make coal-derived liquids much less desirable. Both Burlington Northern and Union Pacific are now testing liquefied natural gas as a locomotive fuel. It should be much cleaner burning.

\subsubsection{Military Jet Fuel}

Coal-derived liquids could provide the feedstock for high-energy-density jet fuels for advanced military aircraft. This possibility was explored in the 1988 market assessment, and it was concluded that this was not a practical option for mild gasification liquids. Since then, the greatly lowered expectations for future military spending have made it even less practical.

\subsection{Nonfuel Liquid Products}

As discussed in the original assessment, there is a wide variety of chemical compounds to be found in the liquids produced by mild gasification. If it is desired to turn these liquids into marketable products, it may be necessary to transform some of the components into chemical compounds with more desirable properties. Several approaches are possible:

- Find a use for the entire stream

- Separate the stream into two or more broad mixtures for sale

- Separate out and sell the individual components

- Transform the entire stream

- Transform the broad mixtures

- Transform the individual components

The farther downstream one carries the market assessment, the higher the value of the product finally sold. Many analyses then attempt to carry back some of the profit gained on downstream processing steps and use this income to improve the economics of the original production step. As an example, one could consider extracting phenol from the liquid stream, making methanol and then formaldehyde from the gas stream, combining the two streams to make phenol-formaldehyde resins, and use the price of these resins to carry out the market assessment. This type of procedure should be avoided. The marketing assessment generally should not be carried past the identification of the first salable product. If that product is available from other sources, then any profits to be made by downstream businesses in transforming that product into higher-value products should be excluded from the analysis. If not, and a plant were built on the basis of the integrated economies by using downstream profits to support the initial production step, a competitor could purchase the intermediate product from the other sources and drive the integrated plant out of business. Therefore, only first-salable-product liquids will be discussed.

\subsubsection{Benzene, BTX}

Historically, benzene was recovered from coke-oven light oil. Now, however, almost all of the benzene and BTX (benzene, toluene, zylene) aromatics in the United States are now derived from petroleum. Benzene prices in the last few years have been extremely 
volatile (Figure 22). The CAAA of 1990 are requiring refiners to remove benzene from gasoline. As a result, benzene production becomes less attractive than befor 9 .

\subsubsection{Carbon Black Feedstock}

Carbon black feedstock must be highly aromatic and completely vaporizable, with low levels of asphaltenes. Mild gasification liquids would have these general attributes, but would be unable to meet the specifications for specific gravity and boiling range. The ideal carbon black feedstock has at least two fused aromatic rings, while the mild gasification liquids are essentially monoaromatic.

Carbon black feedstock was judged to be of low interest because there is no potential for realizing a higher price than that for residual fuel oil. That situation is unchanged.

\subsubsection{Creosote}

United States production of creosote for the years 1967 to 1990 is shown in Figure 23. A significant decline on the order of $40 \%$ occurred after about 1974. In the last few years, however, production has been reasonably stable. At the time of the 1988 market assessment, creosote prices had declined sharply. They have since recovered somewhat (Figure 24). Creosote prices are generally closely related to, but higher than, crude oil prices.

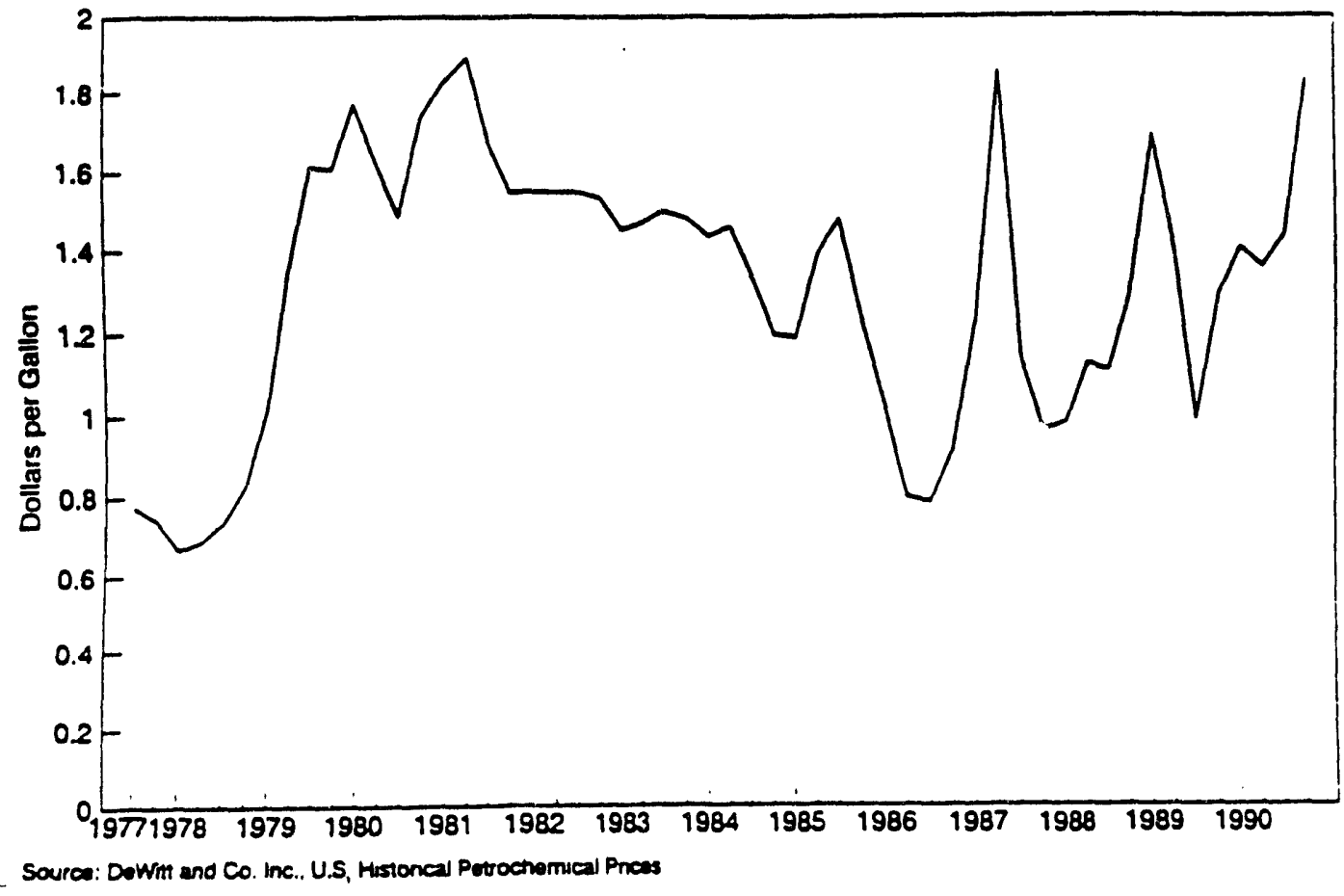

Figure 22. Historical benzene prices. 


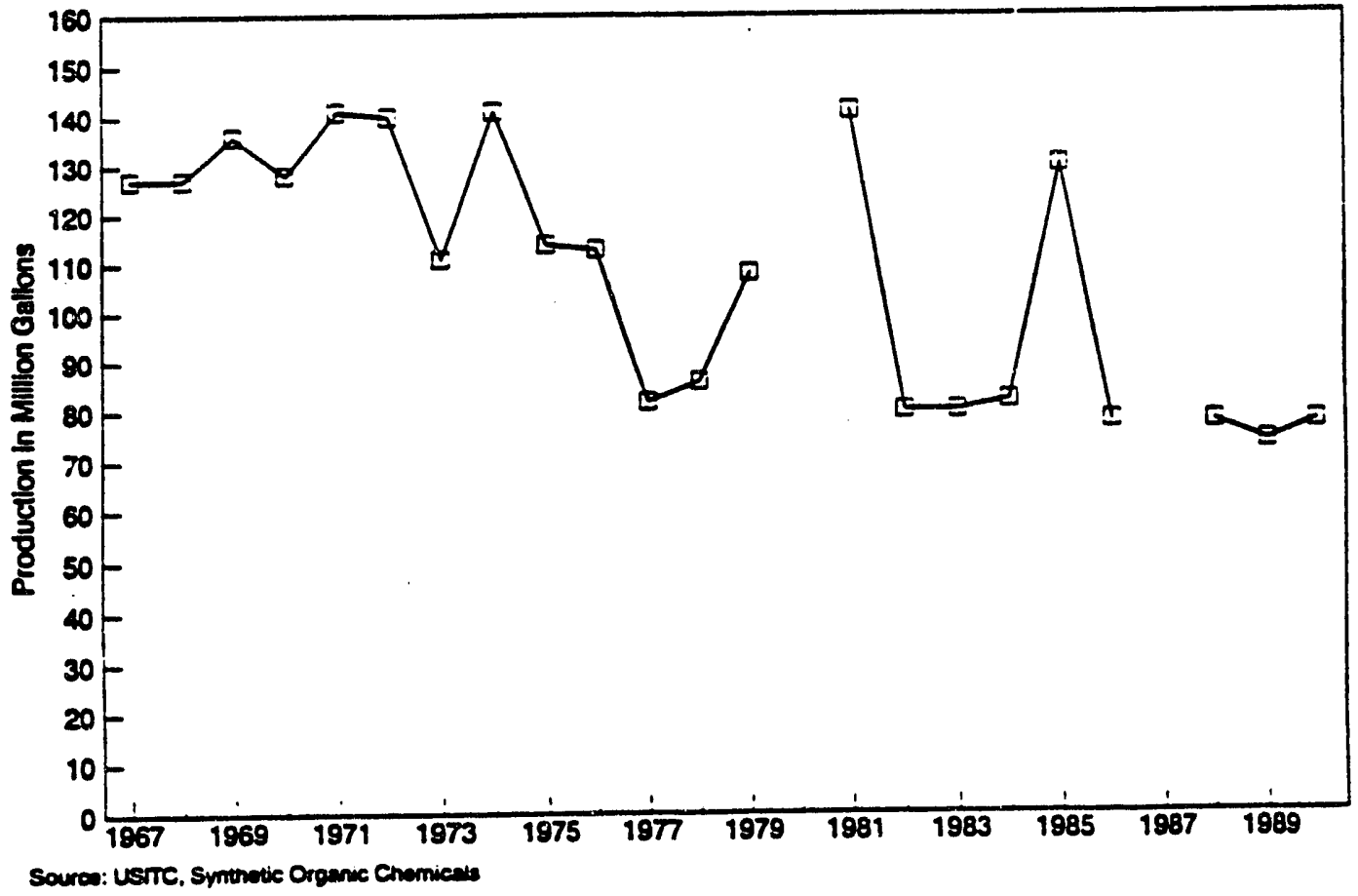

Figure 23. Creosote production.

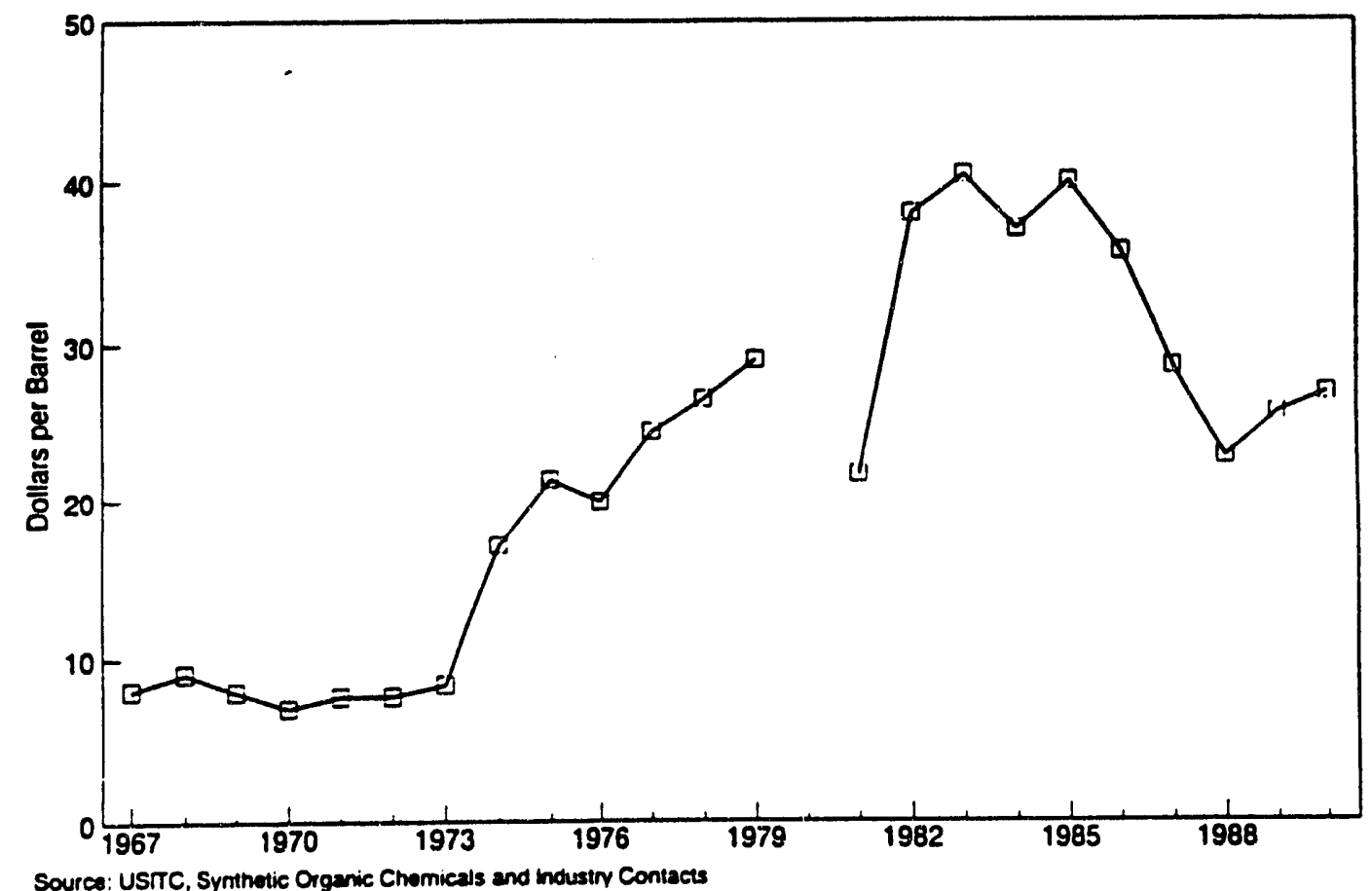

Figure 24. Creosote prices. 
The 1988 market assessment concluded that creosote production might drop below 50 million gallons per year in the 1990s. The trend in Figure 23 would not yet confirm that prediction, but market factors pointing to lower use of creosote in the future have not changed. Creosote would probably be one of the easiest markets to penetrate with mild gasification liquid if it could be demonstrated to meet specifications and not have an unsatisfactory odor.

\subsubsection{Cresols and Cresylic Acid}

The phenolic fraction of the liquid from mild gasification will contain mostly monohydric "phenols," which include phenol, cresols, xylenols, ethylphenols, and other alkylphenols as well as some polyhydric "phenols," including catechols and resorcinol.

The term "cresols" is used to designate the isolated monomethyl phenols, either as pure ortho, meta, or paraisomers or as mixtures of isomers.

"Cresylic acid" refers to various mixtures of tar acids, mostly polyhydric phenols and monohydric phenols higher than C6. Cresols may be the chief constituents in some mixtures; in others the xylenols (dimethylphenols) and higher boiling homologues of phenol may predominate. The individual compounds all have boiling points in the range $180^{\circ}$ to $230^{\circ} \mathrm{C}$.

The United States International Trade Commission ceased reporting data on production and prices for cresylic acids after 1988. Data through 1988 are given in Figures 25 and 26. These data include both synthetic and "naturally" derived materials. Prices for individual cresol isomers are higher than for mixtures, by $\$ 0.20$ to $\$ 1.00$ per pound.

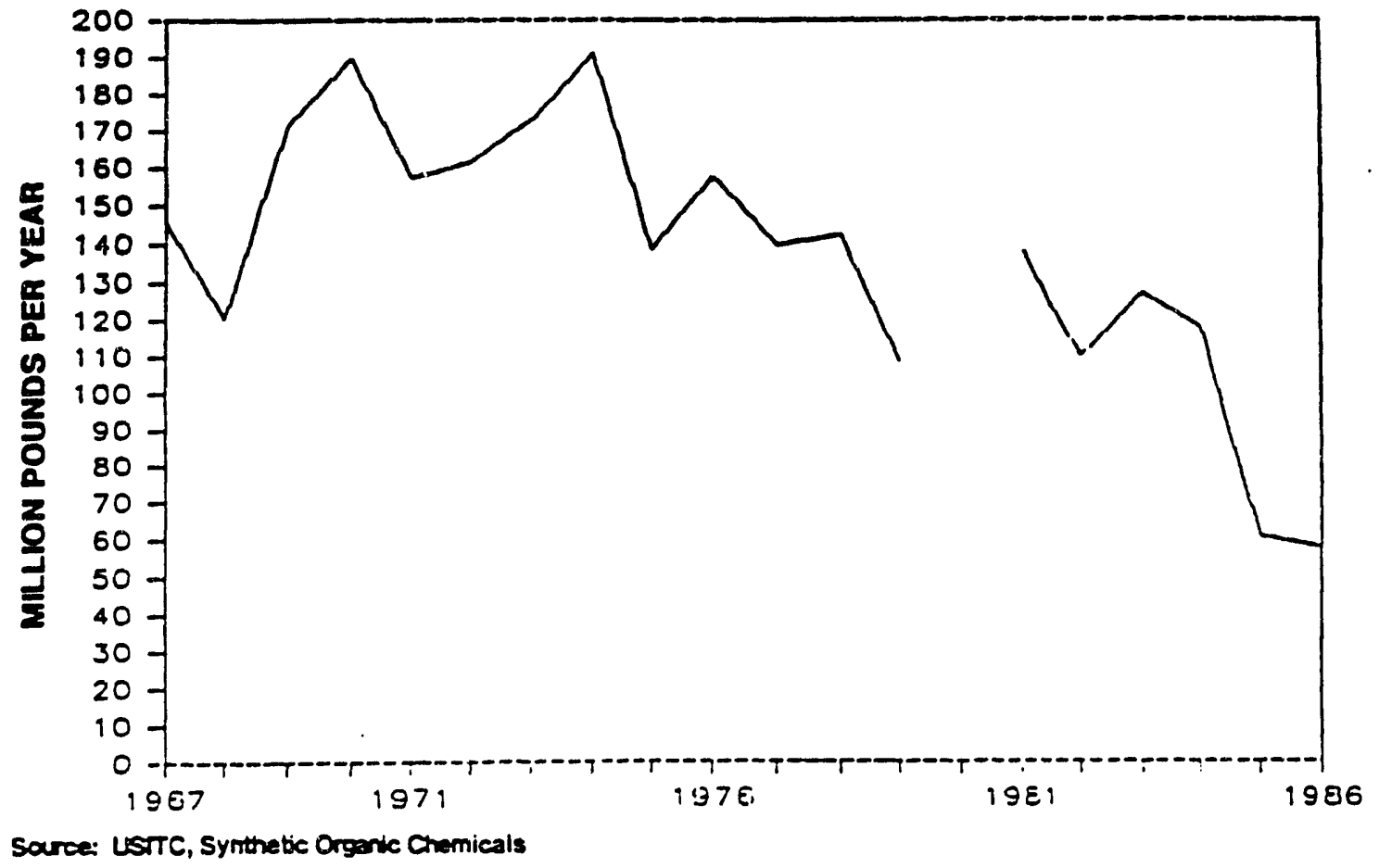

Figure 25. Production of cresols and cresylic acid. 


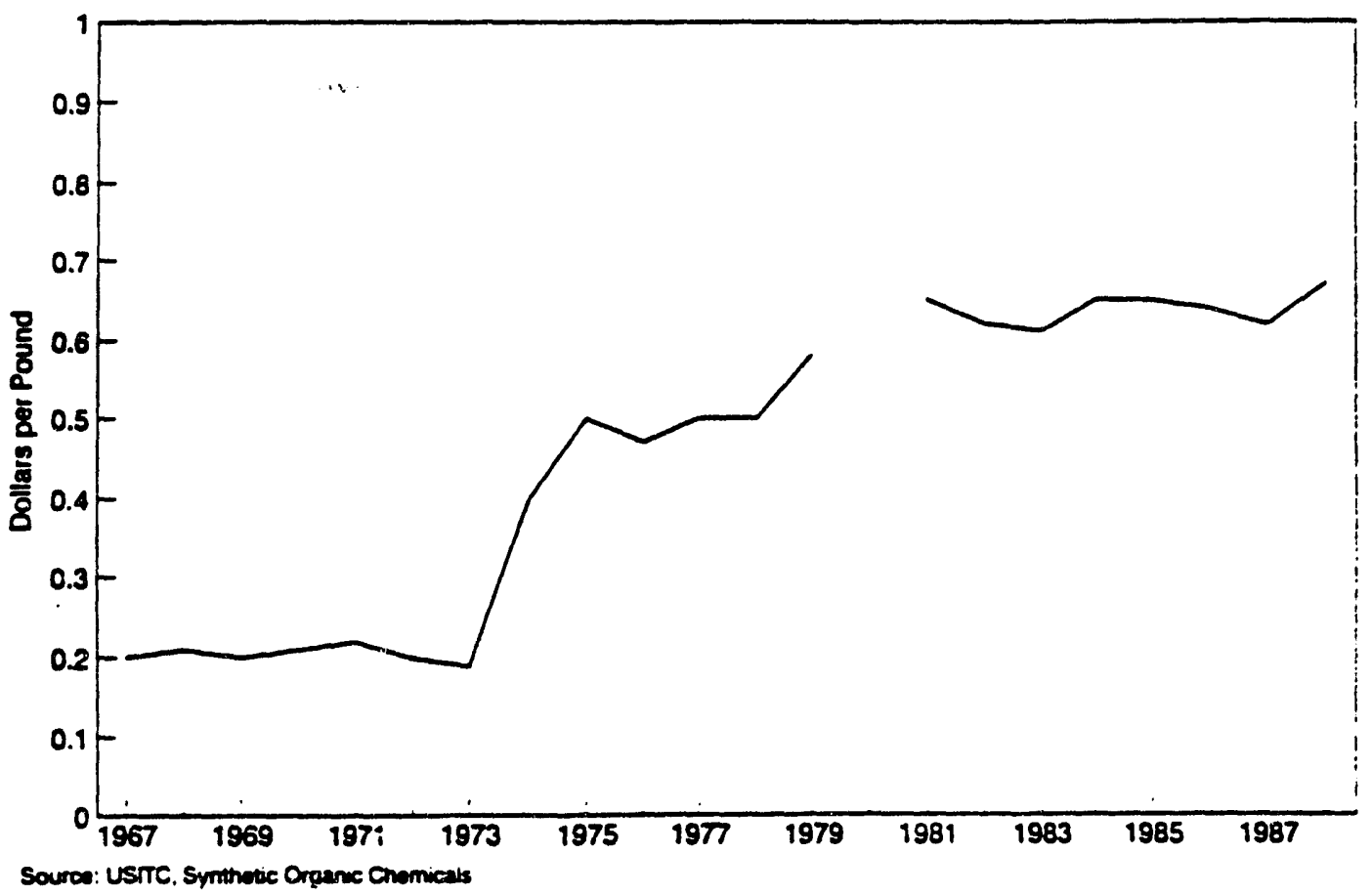

Figure 26. Average prices for cresols and cresylic acids.

An important development in the market situation since the completion of the 1988 market assessment has been the entry of Dakota Gasification Company into the cresylic acid market. The company recently began selling crude cresylic acids produced at the Great Plains coal gasification plant. The Great Plains material should be very similar to what would be produced in a mild gasification process. Great Plains makes about 30 million pounds of crude cresylic acids per year. As seen in Figure 25, this amounts to a large fraction of total U.S. production, and the entry of such a large amount of material into the market creates marketing problems.

Currently Great Plains is exporting half of its production. Originally the company planned to produce refined cresylic acids and spent a considerable sum in building distillation facilities. However, they were unable to solve the difficult technical problems involved with purifying the crude material. This indicates that it would be hazardous for a mild gasification project to consider the same approach. Great Plains is selling its crude product for about $\$ 0.20$ per pound, or only one-third of the prices indicated for refined products in Figure 26.

Another factor on the world market is the expansion of cresylic acid production from Sasol in South Africa. Other than Dakota Gasification Company, the only remaining U.S. domestic producer of natural cresylic acids is Merichem of Houston. Less than 10 years ago there were still five U.S. producers.

The outlook for natural cresylic acids continues to acknowledge two broad, long-term negative factors. One is the general loss of market share by natural products to 
higher-purity synthetic materials. The other is the toxic and carcinogenic nature of coal tar products, which prompts users to find more benign substitutes. Currently, low petroleum prices act to accentuate the conversion to petroleum-derived substitutes.

None of the uses listed for natural cresylics has been identified as a high-growth area. Because petroleum-derived synthetics can substitute for all natural cresylic applications, future demand and price levels will both be constrained by petroleum prices. The outlook, therefore, is for no price increases relative to petroleum and for static or decreasing demand levels.

\subsubsection{Phenol}

The situation for phenol is generally similar to that for cresylic acids, except that the phenol market is much larger. U.S. production of synthetic phenol is over 3 billion pounds per year. The United States International Trade Commission has also discontinued reporting phenol production data after 1998. Data through 1988 are shown in Figure 27. Phenol prices compiled from a variety of sources are shown in Figure 28.

Dakota Gasification Company is now selling about 15 million pounds of crude phenol per year from the Great Plains coal gasification plant. This is only about half their production. They have been unable to sell the remainder because of its off-color and off-odor characteristics. The material that is being sold is going to applications such as foundry core resins where color and odor are not a problem. In this market, they are receiving about $\$ 0.20$ per pound, or only two-thirds the market level indicated in Figure 28. Attempts to upgrade the material to market specifications have been unsuccessful to date. The inability of Great Plains to sell all of its production strongly suggests that crude phenol from a mild gasification plant would face a difficult market.

The 1988 market assessment noted that there should be no problem finding a market if specifications can be met. This conclusion remains true. The study also identified a process--the Dynaphen process-which is supposed to be capable of converting a stream of mixed alkylbenzenes and alkylphenols to benzene plus phenol. If the process can be shown to be economically feasible on a small scale, it would be a way of converting mild gasification phenols and cresols to easily salable products.

\subsubsection{Pitch}

The 1988 market assessment noted that the yield of pitch from mild gasification liquids would be much lower than from coke-oven tars. Although the yield of pitch can be increased by techniques such as air blowing, this has generally been unsuccessful in meeting specifications for electrode binder pitch-the largest single end use. If appreciable quantities of pitch could be derived, it could be an attractive by-product.

Due to the decline in cokemaking in the United States, coal tar pitch production has seen a long-term decline (Figure 29). The resulting shortage of good pitch feedstock for anode production has caused prices to rise over the term (Figure 30 ). Such a rising price trend in the face of declining production indicates that production (availability) is driving prices rather than vice versa. 


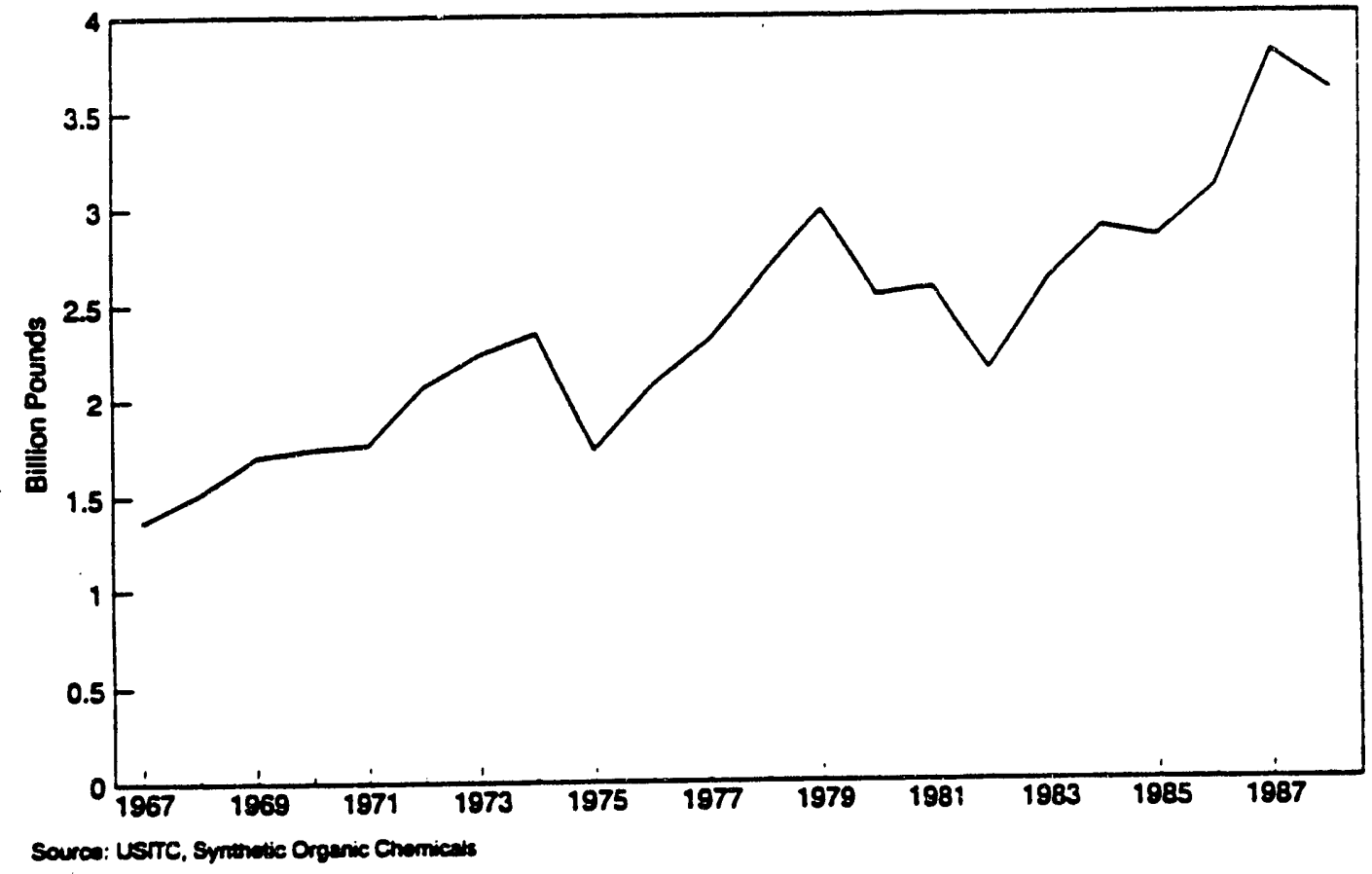

Figure 27. Total United States phenol production.

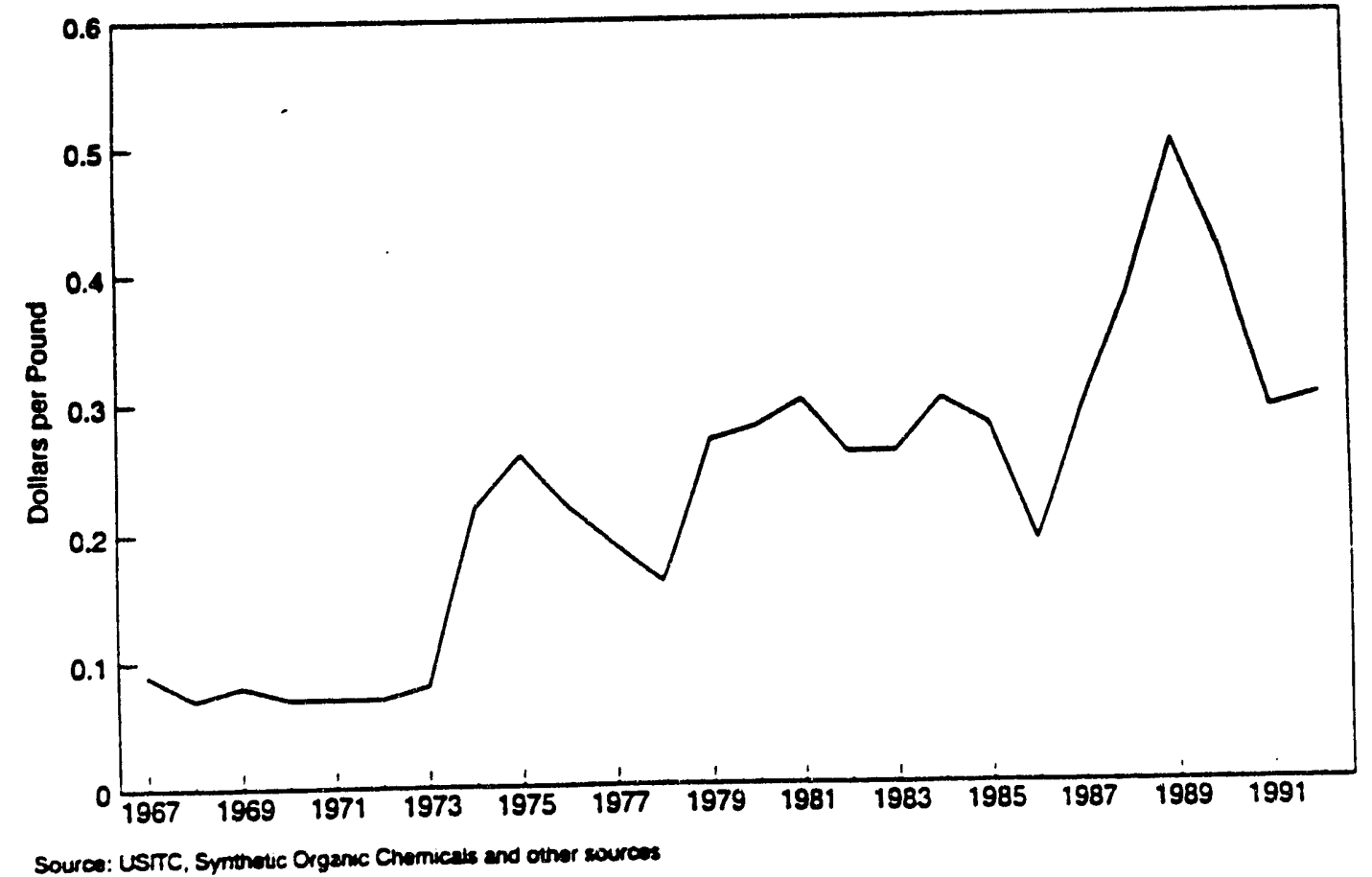

Figure 28. Phenol prices. 


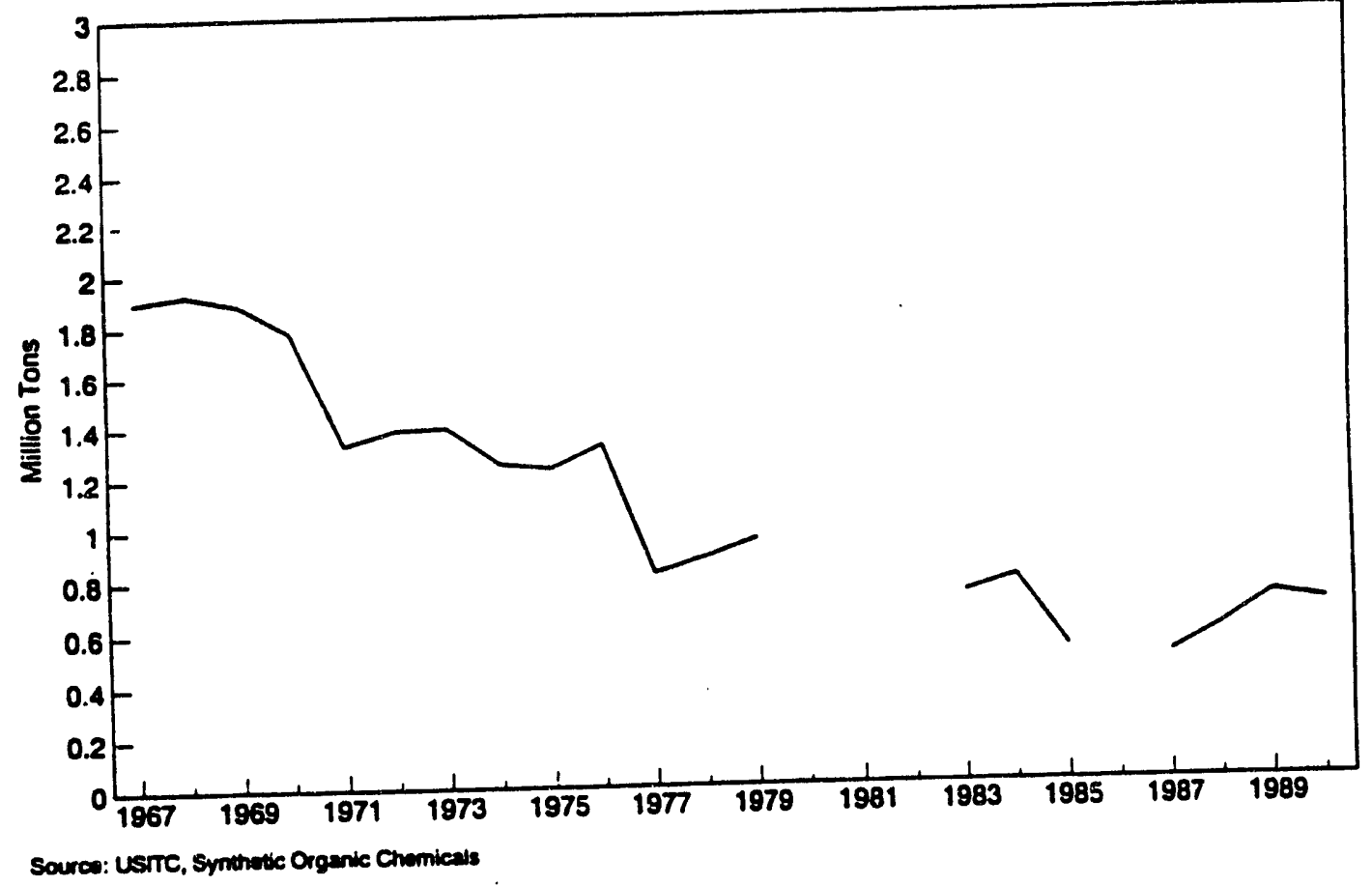

Figure 29. Coal tar pitch production.

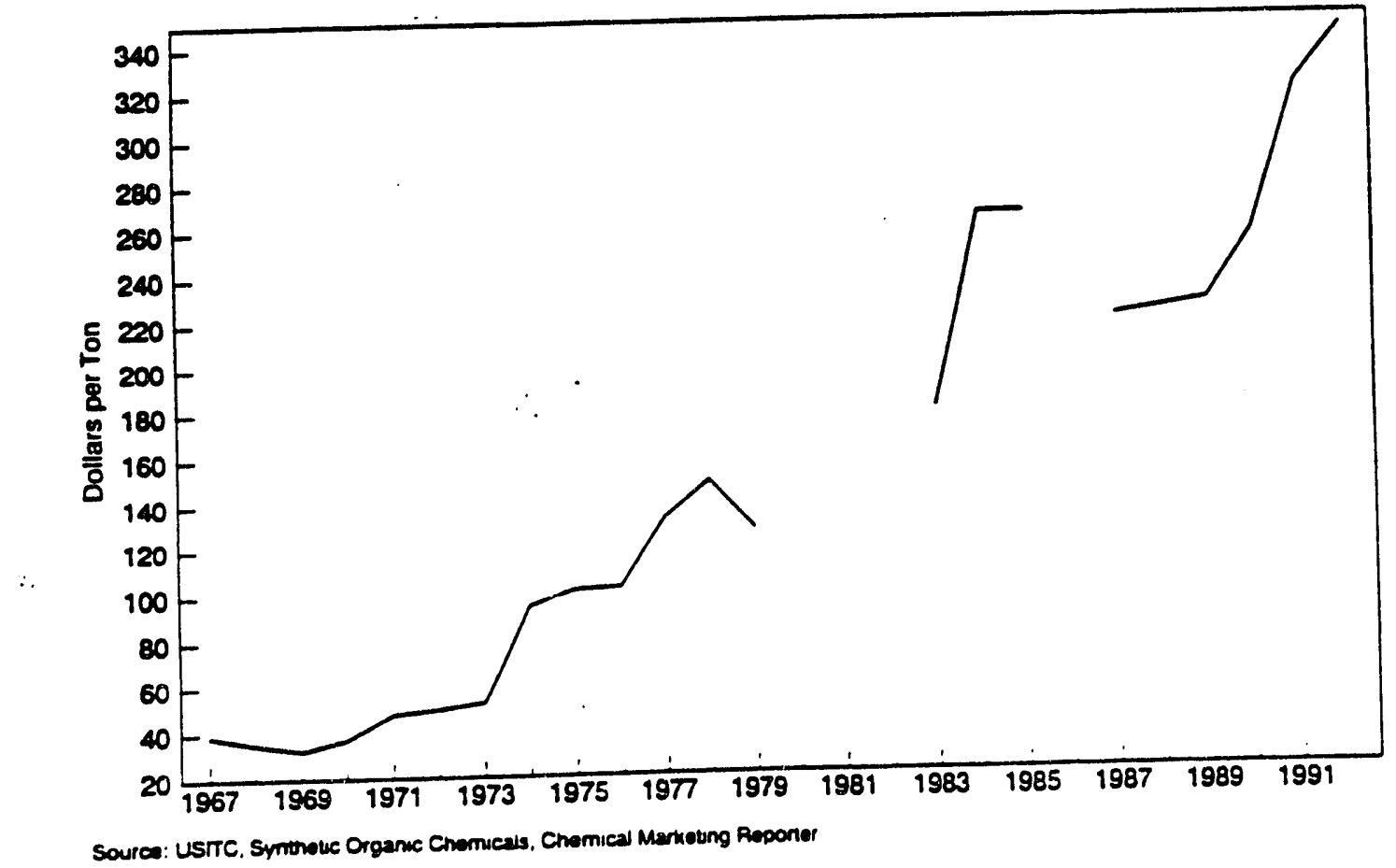

Figure 30. Coal tar pitch prices. 
Aluminum demand is expected to remain strong, growing in proportion to, or slightly faster than, the gross national product. The United States is the world's largest consumer of aluminum, both on an absolute and a per capita basis. Aluminum production is heavily dependent on low-cost electricity, and future production will probably move outside the United States. Therefore, although demand for electrode pitch should remain firm, it is unlikely to increase above current levels.

\subsubsection{Tar Crude}

Trends for production and sales of coke-oven crude tar have changed little since the 1988 market assessment. After a long period of decline, production seems to have stabilized at about 160 million gallons per year (Figure 31). Prices seem to have been little affected by the loss of production (Figure 32), indicating either that demand has fallen in concert with production or that demand actually determines production. The latter is at least partially true for those coke-oven operators who have the option of burning the tar crude for fuel when there is no market for sales. Prices for refined coal tar grade RT-12 have not changed in several years outside the range of $\$ 1.05$ to $\$ 1.25$ per gallon.

It is possible that mild gasification crude liquids could be sold to a tar refiner. However, the product characteristics would be much different than a typical coke-oven tar crude. The market characteristics shown in Figures 31 and 32 do not make an attractive long-term prospect.

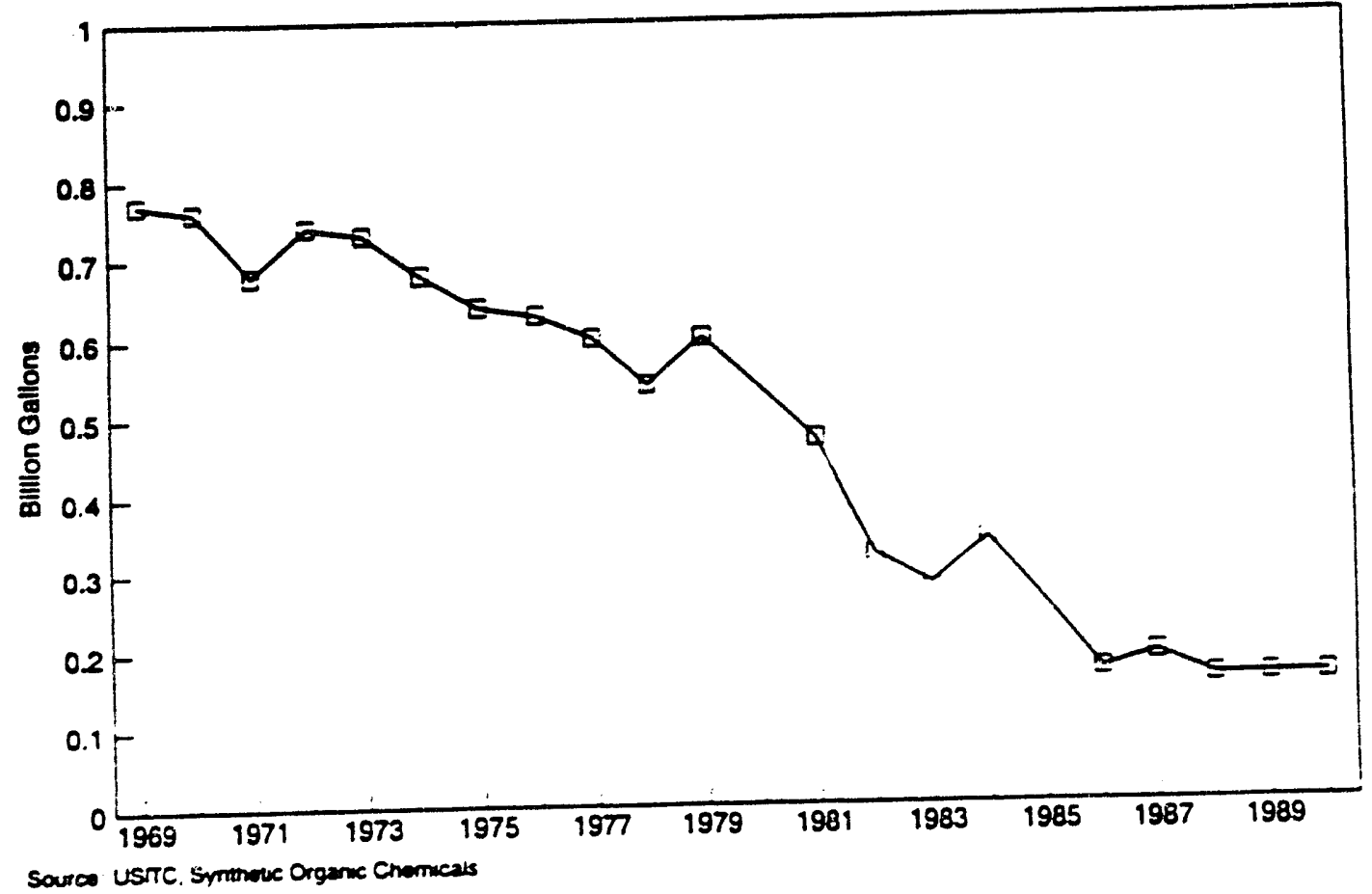

Figure 31. Coal tar production by coke-oven operators. 


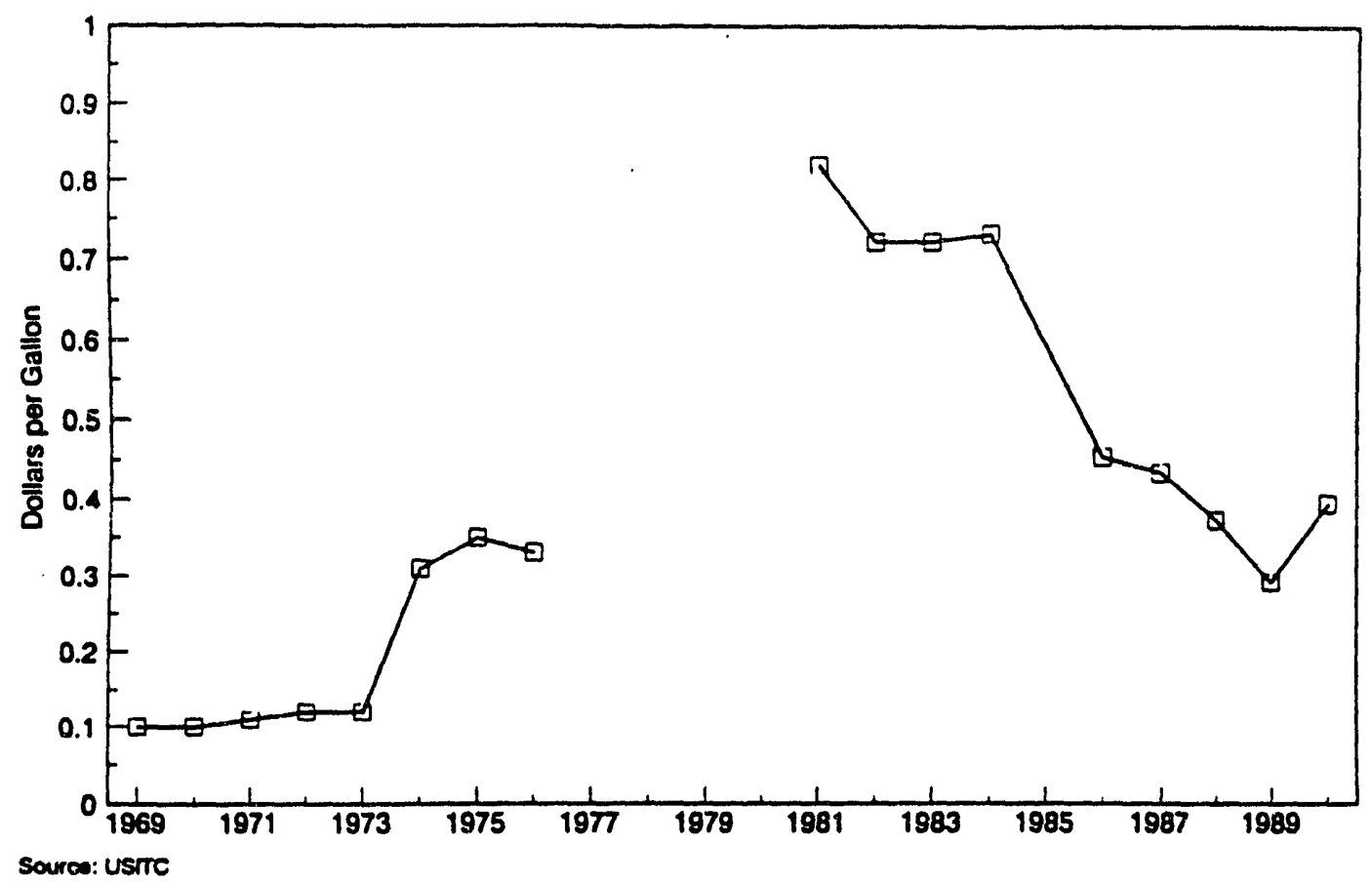

Figure 32. Coal tar prices. 


\subsection{MARKETING}

A strategy for marketing mild coal gasification products, including char, liquids, and gases, is based upon the approach defined in Figure 1. Systems are defined as follows:

- Mild coal gasification technology

- Coal supply, quality, and cleaning

- Iron and steel market

- Activated carbon market

- Coal chemicals market

These interrelated systems constitute unique business sectors which affect and are affected by one another as well as by factors external to each business. Changing market conditions offer new opportunities, but may result in discontinuance of some older, wellestablished businesses.

The objective of this study is to define viable market opportunities for mild coal gasification products even though many attempts have been made to develop commercial coal gasification projects in the past with little success. Some were successful for years (i.e., town gas) only to be replaced by a service or commodity that offers greater value, quality, price, or delivery, as perceived by the customer.

Selection of potential markets for gasification products is first based upon the technical possibilities, namely, the gases, liquids, and solids that have been produced or could be produced to displace products in existing markets, to produce new products, or perhaps to take advantage of a new combination of technology and market conditions.

It is usually easier to move into existing markets with a new source, such as formcoke to replace a diminishing supply of oven coke, but another alternative is to produce activated carbon for the new growth industries of water treatment and gas scrubbing. This approach could reduce the activated carbon market price from the current level of $\$ 0.50$ to $\$ 1.00$ per pound to a much smaller figure, thus expanding market potential. If the spent activated carbon can be fired as boiler fuel instead of being sent to off-site regeneration, the price could be lowered further. Costs for regeneration, transportation, and inventory are reduced while fuel value is used. Previous gasification projects have attempted to compete directly with gas and oil, unsuccessfully. The commodity market is very tough and unforgiving if one cannot meet price and delivery along with specifications. A combination of domestic and imported gas and oil has consistently beat out coal and coal products for the transportation and chemical markets because of fungibility, price, ease of use, flexibility of use, and ease of transport.

Coal has successfully competed against gas and oil in the industrial power generation market, with some exceptions such as fuel switching to achieve environmental requirements. 


\subsection{PROJECT FINANCIAL ANALYSIS}

A preliminary financial analysis was carried out using the capital cost estimate prepared by Xytel-Bechtel (16) and an operating cost estimate prepared by AMAX Research and Development Center.

\subsection{Formcoke Value}

A wide range of opinions exists as to the potential market value of formcoke. Because it is not a currently purchased commodity in the steel industry, there is no precise measure of its value. It is generally expected that formcoke would be somewhat less valuable than conventional metallurgical coke, because the formcoke properties will be less desirable or may require changes in blast-furnace operating procedures. A fully optimized formcoke process could theoretically produce a more uniform product and might eventually command a higher market price. Prices of as much as $\$ 200$ per ton have been suggested for such a premium, low-sulfur product. At the moment, that possibility is purely speculative.

Because only a small fraction of the total amount of coke produced is actually sold in a market transaction, reported prices fluctuate a great deal in response to changing demand. Prices in the past have generally ranged from about $\$ 80$ to $\$ 150$ per ton. Current values appear to lie in the range of $\$ 100$ to $\$ 120$. Prices required for investment replacement are expected to be $\$ 150$ to $\$ 160$ per ton. A value analysis (1) (in which the value of coke was computed as the product of the additional output of steel generated by a marginal increase in coke times the price of steel) led to a price of $\$ 157$ per ton.

The biggest hurdle for a formcoke produced from Indiana coal is to make a product that will be marketable from the standpoint of sulfur content. Standard practice is to set an absolute limit of $1.0 \%$ sulfur in coke. In actuality, there is nothing magic about this value. Higher sulfur levels simply mean more expense in removing sulfur during the steelmaking process. In the United Kingdom, because of the scarcity of low-sulfur coking coals, a sulfur level of up to $1.5 \%$ in metallurgical coke is tolerated (17). However, there seems to be a general consensus that sulfur has to be no higher than $1.0 \%$ for the U.S. market.

In spite of the key importance of sulfur in coke, there is no widely accepted scale for coke value as a function of sulfur content. Depending on the individual coke producer, sulfur penalties or premiums may be assessed on coking coal, ranging from $\$ 1.00$ to $\$ 2.50$ per ton per $0.1 \%$ sulfur above or below a desired level such as $0.7 \%$ If it is assumed that these values flow through to the coke and that they can be extended to higher sulfur levels, a 3\% sulfur coke might have to carry a discount of $\$ 30$ to $\$ 70$ per ton. The lower figure might be acceptable, but there is no indication that a $3 \%$ sulfur coke could be sold even at a much higher discount.

For the purposes of this analysis, it was assumed that a formcoke with no more than $1.0 \%$ sulfur could be produced and that the market value would be between $\$ 100$ and $\$ 200$ per ton. 


\subsection{Electricity Value}

The project case analyzed has only two products: formcoke and electricity. If the project could be structured as a cogeneration facility, it could obtain "qualifying facility" status from the Federal Energy Regulatory Commission. This results in certain financial benefits for the plant owner. The electrical utility in whose service area the plant is built would be required to purchase the electricity produced by such a facility.

Without designation as a cogeneration facility, the formcoke plant would be classified as an independent power producer (IPP). As an IPP, electricity sales would have to be negotiated with a utility. It would not necessarily have to be the utility in whose service area the plant is located. Electricity could be "wheeled" over the transmission lines of the local utility to the final purchaser.

Current electricity purchase prices offered by Indiana utilities are on the order of $\$ 0.03$ per $\mathrm{kWh}$ (combined energy rate and demand rate). However, the current price being paid for electricity by the Chinook mine is on the order of $\$ 0.04$ to $\$ 0.05$ per $\mathbf{k W h}$. Therefore, power could be supplied to the mine by the mild gasification plant to realize an internal income of up to $\$ 0.05$ per $\mathbf{k W h}$. In the future, when the utilities again begin building new generation facilities, it is expected that their aroided cost could go as high as $\$ 0.07$ per $\mathrm{kWh}$. Therefore, the electricity prices used for a sensitivity analysis were $\$ 0.03, \$ 0.05$, and $\$ 0.07$ per $\mathrm{kWh}$.

\subsection{Product Rates}

\subsubsection{Formeoke}

To obtain a product flow rate for use in the financial analysis, the following streams from the XBI report were used:

- 13a, calcinaté, 25,100 lb/hr

- 15 , calcinate fines, $5,614 \mathrm{lb} / \mathrm{hr}$

- 20 , tar oil, 5,278 lb/hr

Streams $13 a$ and 15 are at $7 \%$ volatiles content, while the final formcoke product is assumed to be at $2.5 \%$ volatiles. Furthermore, it was assumed that $40 \%$ of the tar oil used as binder is volatilized during briquette curing. Therefore, total product yield was computed by:

- Stream 13a, 25,100 = $0.955=23,970 \mathrm{lb} / \mathrm{hr}$

- Stream $15,5,614 \times 0.955=5,361 \mathrm{lb} / \mathrm{hr}$

- Stream $20,5,278$ × $0.60=3,167 \mathrm{lb} / \mathrm{hr}$

- Total $=32,498 \mathrm{lb} / \mathrm{hr}$

On the basis of 330 days per year, total formcoke product for revenue is then 128,700 tons per year. 


\subsubsection{Electricity}

The gross plant electrical capacity in the XBI design is 24 megawatts, with a net output for sale of 19.2 megawatts. On the same basis of 330 days per year, the total production for revenue is 152 million $\mathrm{kWh}$ per year. It appears that this figure may be low because it is not clear that the fuel value of that fraction of the binder volatilized during curing has been added to the fuel stream. If that is the case, electrical output should be increased by over $10 \%$.

\subsection{Capital Cost}

The total capital cost determined by XBI is $\$ 116.4$ million in 1992 dollars. A 3-year construction schedule was assumed, with expenditure profile as follows:

- $40 \%$ in 1995

- $30 \%$ in 1996

- $30 \%$ in 1997

The first year of production is 1998, and production starts at full capacity. Operating life is 20 years, and a salvage value of $20 \%$ of capital cost was assumed.

\subsection{Operating Cost}

\subsubsection{Coal}

The major operating cost is the cost of coal. Plant input is 1000 tons per day, dry basis, at $8.2 \%$ moisture. This translates to 1,089 tons per day wet basis, or 359,477 tons per year. It takes 2.79 tons of coal to produce a ton of formcoke.

The nominal price of coal is $\$ 20$ per ton, and sensitivity cases were run at $\$ 15$ and $\$ 25$ per ton.

\subsubsection{Limestone}

To calculate limestone required for sulfur removal, the following data were used:

- $90 \%$ sulfur removal efficiency

- 2047-lb/hr sulfur removed

- 1.8 stoichiometric ratio calcium/sulfur

- Limestone $=56 \% \mathrm{CaO}$

- 45,600-ton/yr limestone

- Cost of crushed limestone $\$ 7 /$ ton

- Total cost $\$ 319,000$ 


\subsubsection{Disposal Costs}

Fly ash and spent limestone/gypsum are disposed of in the coal mine. Disposal costs were calculated as follows:

- $5,375 \mathrm{lb} / \mathrm{hr}$ fly ash

- $5,117 \mathrm{lb} / \mathrm{hr}$ excess limestone

- 11,000 lb/hr gypsum (CaSO4-2H2O)

- Disposal cost \$2/ton

- Total cost $\$ 170,200 / y r$

\subsubsection{Water}

Water requirements were calculated as follows:

- Cooling tower heat load 350 million BTU/hr

- Assume 75\% latent heat transfer

- $270,600 \mathrm{lb} / \mathrm{hr}$ evaporated, 32,000 $\mathrm{gal} / \mathrm{hr}$

- Adding blowdown and drift, need 40,000 gal/hr

- 317 million gal/yr

- Cost $\$ 0.50$ per 1,000 gal

- Total cost $\$ 158,400 / \mathrm{yr}$

\subsubsection{Chemicals}

Water treatment chemicals include:

- Biocide for cooling tower, \$32,000/yr

- Boiler feed water treatment, $\$ 24,000 / y r$

- Make-up brine and glycol, \$8,000/yr

- Total cost $\$ 64,000 / y r$

\subsubsection{Supplies and Maintenance}

Calculated as 2.5 percent of capital cost, or $\$ 2,910,000 / y r$.

\subsubsection{Labor}

Operating labor costs were estimated as follows:

- Operations, 40 persons, $\$ 2,617,000 / y r$

- Support, 10 persons, $\$ 482,000 / y r$

- Engineering, 7 persons, $\$ 534,000 / \mathrm{yr}$

- Supervision, 7 persons, $\$ 591,000 / y \mathbf{r}$

- Total cost $\$ 4,224,000 / y r$

\subsubsection{Operating Cost Summary}

Total operating costs amount to $\$ 15,041,000$ per year, as summarized in Table 17 . 


\section{TABLE 17}

Operating Cost Summary (Dollars per Year)

Totals

Feedstocks

Coal (\$20/ton)

$\$ 7,190,000$

Limestone

$\$ 319,000$

Chemicals

Disposal

Supplies and Maintenance

Utilities

Gas

Water

Wastewater

$\$ 7,509,000$

$\$ 64,000$

$\$ 170,000$

$\$ 2,910,000$

Labor

Operations

$\$ 2,617,000$

Support

$\$ 482,000$

Engineering

$\$ 534,000$

Supervision

$\$ 591,000$

$\$ 164,000$

Grand Total

$\$ 4,224,000$

$\$ 15,041,000$

\subsection{Financial Evaluation}

\subsubsection{Evaluation Parameters}

Financial analyses were carried out using the following parameters:

- $4 \%$ general inflation rate

- All costs and revenues inflated at $4 \%$ per year

- $100 \%$ equity basis

- Trxes calculated on stand-alone project basis

- Project subject to Indiana income taxes

\subsubsection{Base-Case Results}

Base-case results are combined with a capital cost sensitivity analysis in Figure 33 and T $\mathrm{vble} 18$. For the best-guess capital cost estimate of $\$ 116.4$ million, the discounted cash flow rate of return (DCFROR) is $8.1 \%$ at a formcoke price of $\$ 150$ per ton. Increasing the capital cost by $20 \%$ drops the rate of return to $6.9 \%$, and decreasing the capital cost by $20 \%$ increases the rate of return to $9.6 \%$. 
The calculated rate of return is not sufficiently attractive to draw outside investors into such a project. The major reason for the poor economics as compared to conventional coke ovens is the small plant size and consequent high cost per unit of capacity. In terms of unit cost, the mild gasification formcoke plant costs $\$ 900$ per yearly ton of capacity, about 3 times the estimated cost for conventional coke ovens. This overwhelms the fact that cheaper coals can be used as feedstock. This size does not appear to be an attractive commercial venture. A plant of this size should more properly be considered a demonstration project and not be expected to earn full commercial rates of return on investment.

\subsubsection{Sensitivity to Electricity Prices}

The effect of three different levels for the price of electricity is shown in Figure 34 and Table 19. The nominal level of $\$ 0.05 / \mathrm{kWh}$ corresponds to electricity replacement cost at the Chinook mine. As before, the indicated rate of return is $8.1 \%$ at a coke price of $\$ 150 /$ ton. Decreasing the price of electricity to $\$ 0.03 / \mathrm{kWh}$, the current avoided cost offered by Indiana utilities, drops the rate of return to 5.8\%. Increasing the price of electricity to $\$ 0.07 / \mathrm{kWh}$, the expected future value, increases the rate of return to $10.1 \%$. Electricity prices thus have a major effect on the project's financial performance.

\subsubsection{Sensitivity to Coal Cost}

The effect of three different levels for coal cost is shown in Figure 35 and Table 20. The nominal level of $\$ 20 /$ ton corresponds to the expected cost of coal from the Chinook mine. As before, the indicated rate of return is $8.1 \%$ at a coke price of $\$ 150 / \mathrm{ton}$.

Increasing the cost of coal to $\$ 25 /$ ton decreases the rate of return to 6.8\%. Decreasing the cost of coal to $\$ 15 /$ ton raises the rate of return to $9.4 \%$. Although the effect is significant, coal cost swings of this magnitude cannot push the project into an attractive financial regime.

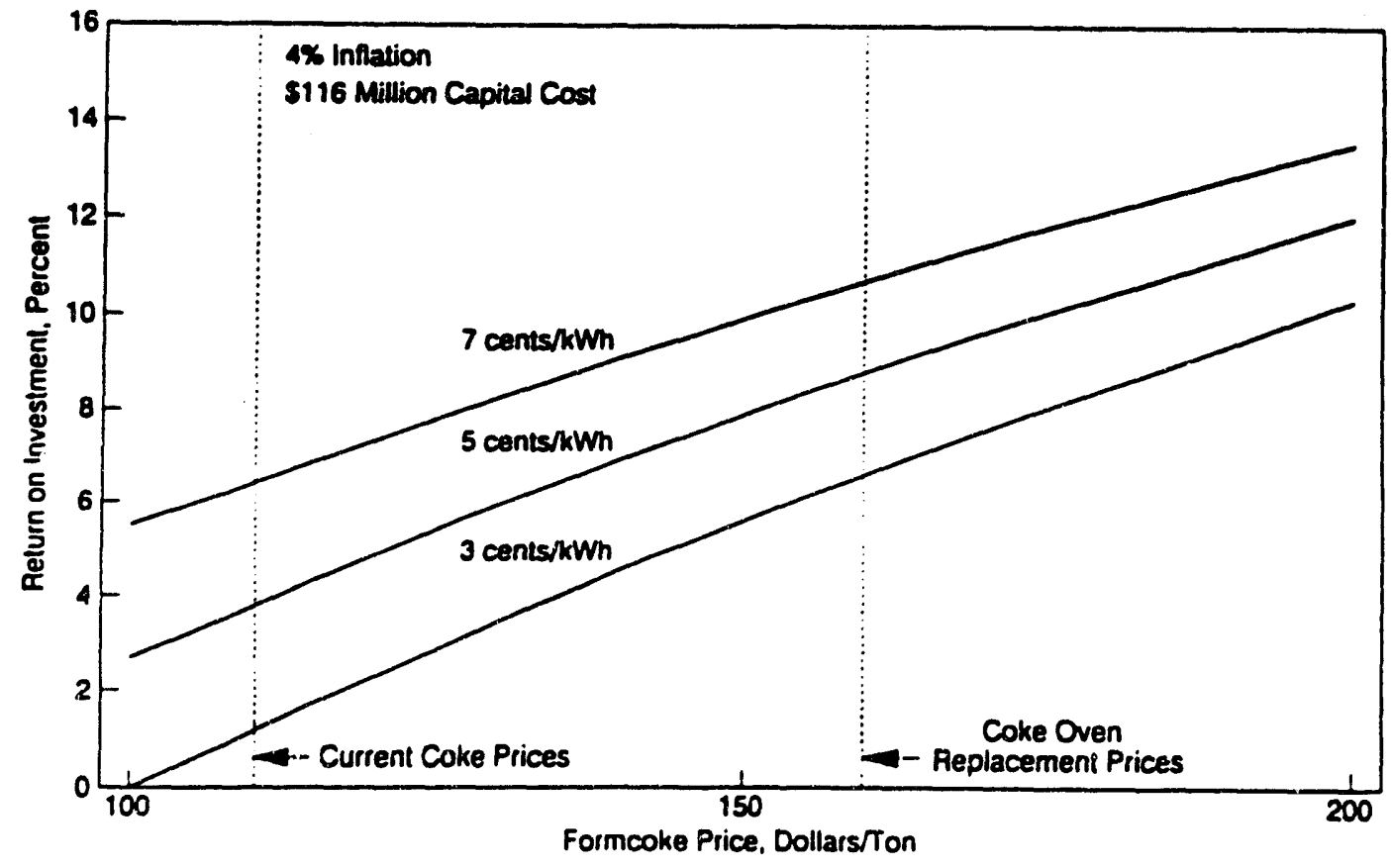

Figure 34. DCFROR as a function of formcoke and electricity prices. 
Electricity Price Sensitivity (Discounted Cash Flow Rate of Return, Percent)

DCFROR

Nominal electricity price $(\$ 0.05 / \mathrm{kWh})$

Coke price $\$ 100 /$ ton

2.7

Coke price $\$ 150 /$ ton

8.1

Coke price $\$ 200 /$ ton

12.0

Increased electricity price $(\$ 0.07 / \mathrm{kWh})$

Coke price $\$ 100 /$ ton

Coke price \$150/ton

Coke price $\$ 200 /$ ton

Decreased electricity price $(\$ 0.03 / \mathrm{kWh})$

Coke price \$100/ton

Coke price $\$ 150 /$ ton

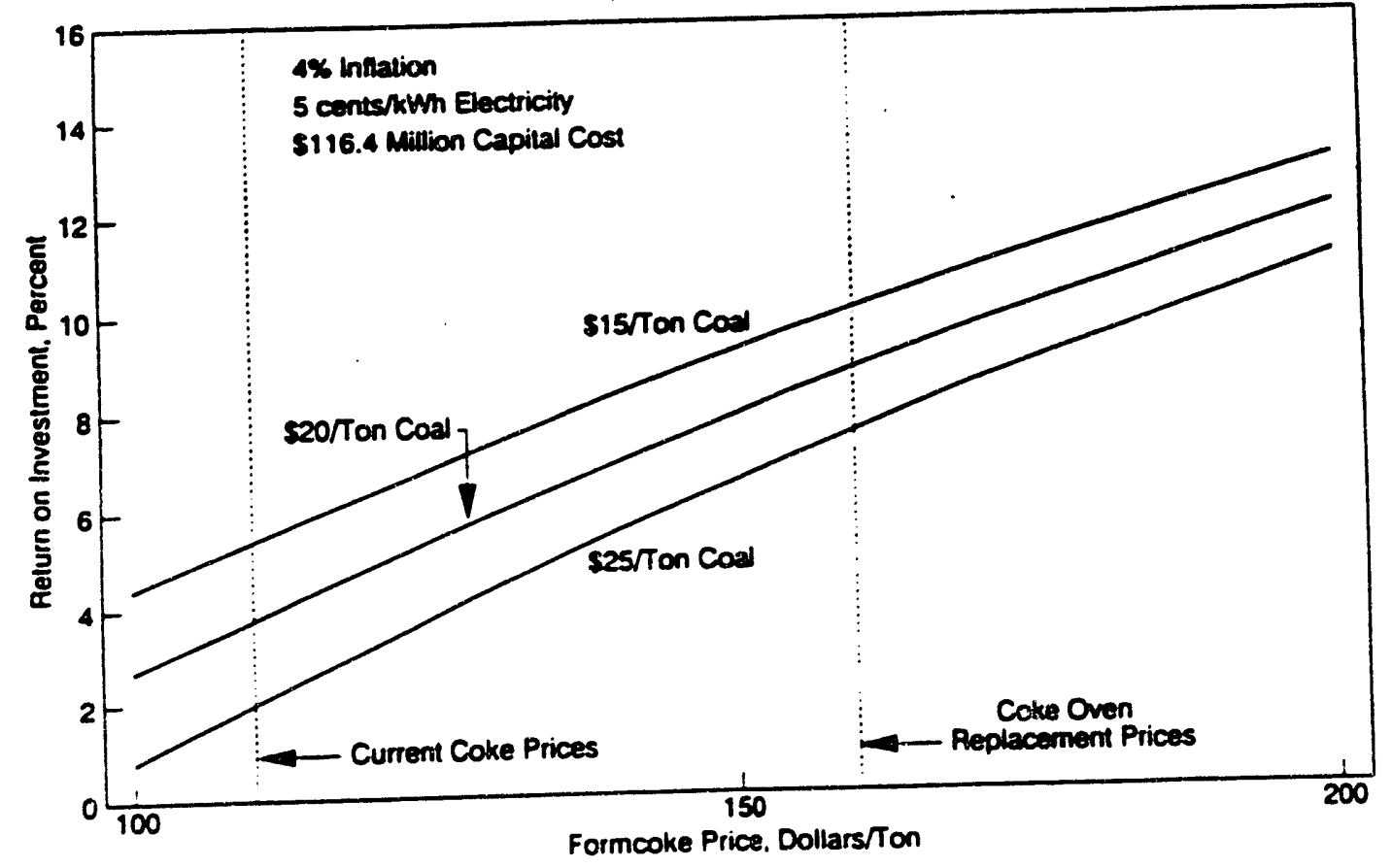

Figure 35. DCFROR as a function of coal costs and formcoke prices. 


\begin{tabular}{cc}
\hline & DCFROR \\
\hline Nominal coal cost $(\$ 20 /$ ton) & \\
Coke price $\$ 100 /$ ton & 2.7 \\
Coke price $\$ 150 /$ ton & 8.1 \\
Coke price $\$ 200 /$ ton & 12.0 \\
Decreased coal cost $(\$ 15 /$ ton $)$ & \\
Coke price $\$ 100 /$ ton & 4.4 \\
Coke price $\$ 150 /$ ton & 9.4 \\
Coke price $\$ 200 /$ ton & 13.0 \\
Increased coal cost $(\$ 25 /$ ton $)$ & \\
Coke price $\$ 100 /$ ton & 0.8 \\
Coke price $\$ 150 /$ ton & 6.8 \\
Coke price $\$ 200 /$ ton & 11.0 \\
\hline
\end{tabular}

\subsubsection{Probability Distribution on Cost Sensitivity}

A final economic run investigated the result of a probability distribution on capital costs. The results shown earlier in Figure 33 simply give the values (DCFROR) which would result from specific changes in capital cost. In reality, capital cost may be thought of as a random variable whose most likely value is the estimate of $\$ 116.4$ million. If the plant is actually built, it could end up costing less than the estimate, but is far more likely to end up costing more than the estimate. This effect can be analyzed using the technique of Monte Carlo analysis.

A triangular probability distribution for capital costs was assumed, with $\$ 116.4$ million as the most likely value, $\$ 92.8$ million as the lower limit, and $\$ 151.3$ million as the upper limit. Using a random number generator to choose capital values from the triangular probability distribution, several hundred computer runs were then made to generate probability distributions for the discounted cash flow return on investment as a function of formcoke prices. Results are presented in Figure 36 and Table 21. Shown are the DCFROR values for $10 \%, 25 \%, 50 \%, 75 \%$ and $90 \%$ probabilities. These may be interpreted as follows. For any given coke price, there is a $90 \%$ probability that the DCFROR will exceed the values on the lower line in Figure 36, a 75\% probability that the DCFROR will exceed the values on the second lowest line, a $50 \%$ probability that the DCFROR will exceed the values on the middle (heaviest) line, etc. Thus the thickness of the lines in Figure 36 indicates, in a qualitative way, the likelihood of the actual project rate of return falling in the vicinity of the line. It is most likely to fall near the middle line and increasingly less likely to fall on the lines farther away from the middle. Because cost overruns are more likely than cost underruns, the probable DCFROR is shifted toward the lower lines. Thus, as seen in Table 21, the base-case rate of return (50\% probability) at $\$ 150$ coke price is $7.9 \%$ compared to $8.1 \%$ for the nominal case in Table 18. 


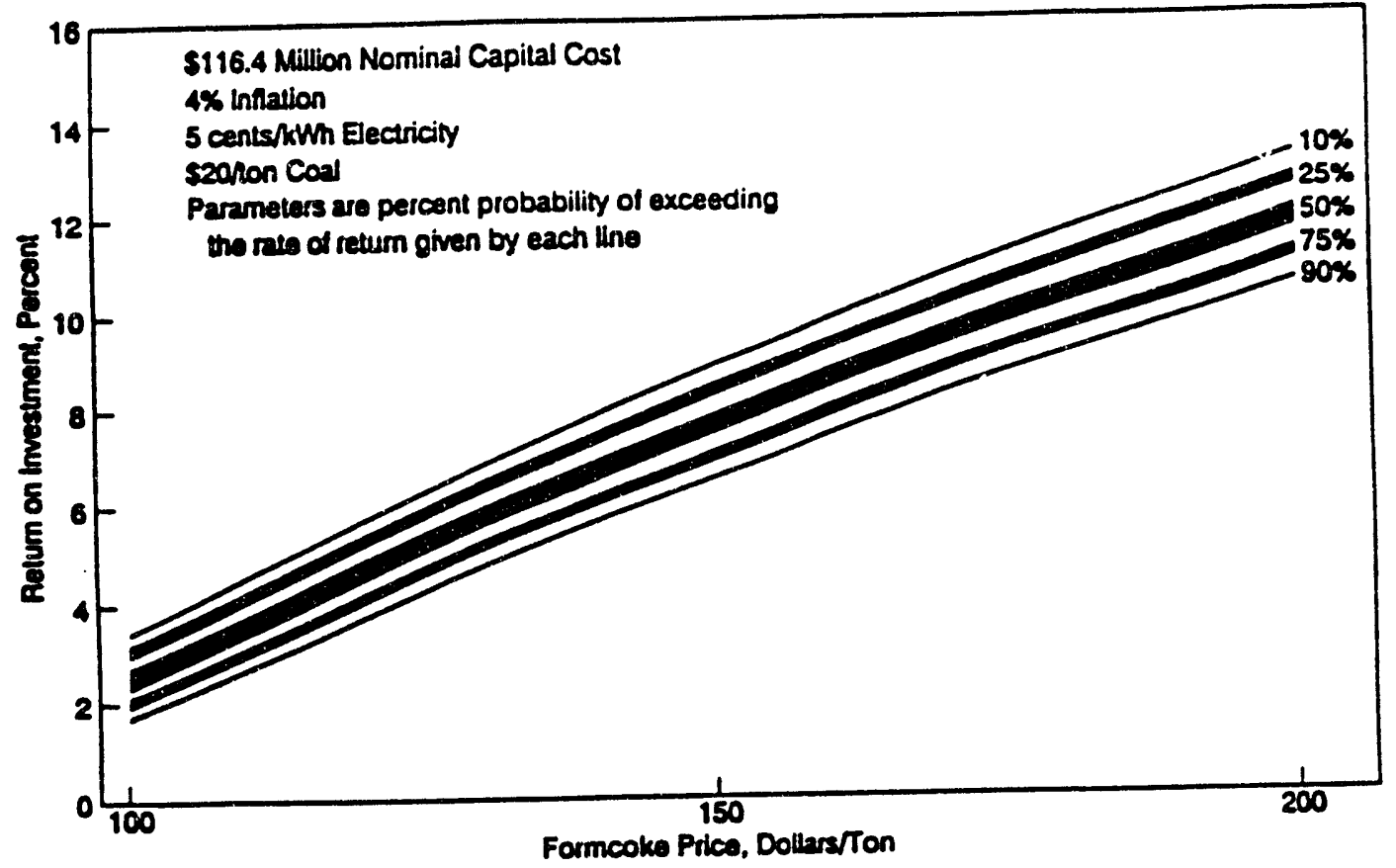

Figure 36. DCFROR as a function of capital cost and formcoke prices.

TABLE 21

Probability Distribution on DCFROR as a Function of Capital Cost and Coke Prices (Probability, Percent of Reaching or Exceeding the Specified Discounted Cash Flow Rate of Return, Percent)

\begin{tabular}{lcc}
\hline & Probability, Percent & DCFROR, Percent \\
\hline Formcoke price \$100/ton & 90 & 1.69 \\
& 75 & 2.09 \\
& 50 & 2.50 \\
Formcoke price \$150/ton & 25 & 2.96 \\
& 10 & 3.41 \\
& 90 & 6.76 \\
& 75 & 7.33 \\
Formcoke price \$200/ton & 50 & 7.89 \\
& 25 & 8.51 \\
& 10 & 9.12 \\
& 90 & 10.55 \\
& 75 & 11.19 \\
& 50 & 11.83 \\
& 25 & 12.53 \\
\hline
\end{tabular}




\subsection{REFERENCES}

1. Research Triangle Institute (1991). "Controlling Emissions from By-Product Coke Oven Charging, Door Leaks, and Topside Leaks: Economic Impacts of Candidate NESHAP," draft report prepared for T.G. Walton, Office of Air Quality Planning and Standards, United States Environmental Protection Agency, August.

2. Peters, A.T. (1991). "The Effects of the Clean Air Act, Amendment of 1990 on the U.S. Coke and Steel Industry and Foreign Trade Balance," United States Depa-tment of the Interior, Bureau of Mines, September.

3. Prabhu, D.U., and P.F. Cilione (1992). "1990 Clean Air Act Amendments: Technical/Economic Impact on U.S. Coke and Steelmaking Operations," United Engineers and Constructors, Inc., Philadelphia, Pennsylvania, January.

4. Lepinski, J.A. and D.C. Meissner (1991). "Coal-Based Ironmaking with the Fastmet Process," presentation at the Eighth Annual International Pittsburgh Coal Conference, Pittsburgh, Pennsylvania, October 14-18.

5. Midrex Corporation (1991). Direct from Midrex, First Quarter.

6. Farren, J.M., T.J. Hauser and J.C. Lake (1992). "U.S. Industrial Outlook '92: Business Forecasts for 350 Industries," United States Department of Commerce, January.

7. Current Industrial Reports, Inorganic Chemicals (p. 40).

8. Roskill Information Services Ltd. (1990). The Economics of Activated Carbon, Third Edition 1990, London, England, April.

9. Lowe, P.A. B. St. John and B.J. Zakheim (1991). "Mild Gasification Chars for Use as a Source of Activated Carbon," report for the Ilinois Center for Research on Sulfur in Coal.

10. J.E. Sinor Consultants, Inc. (1992). "Market Assessment for North Dakota Lignite," report prepared for the North Dakota Industrial Commission, April.

11. United States Environmental Protection Agency. "Municipal Waste Combustors-Background Information for Proposed Guidelines for Existing Facilities," EPA-450/3-89-27e.

12. Kassebohm (1990). "The Costs of Flue Gas Desulphurisation," Institute of Energy Seminar, London, England, September 19.

13. United States Environmental Protection Agency. Air Pollutant Emission Standards and Guidelines for Municipal Waste Combustors: Revision and Update of Economic Impact Analysis and Regulatory Impact Analysis, EPA-450/3-91-003.

14. Knudson, C.L. 1992. Personal Communications. 
15. Chow, W., M. Miler and J. Fortune (1991). "Managing Air Toxics Under the New Clean Air Act Amendments," Power Engineering, January.

16. Xytel-Bechtel, Inc. (1992). "Conceptual Design and Budget Estimate for a 11,000 T/D Mild Coal Gasification Facility," for the University of North Dakota Energy and Environmental Research Center and AMAX Coal Company Research and Development Center, April.

17. Loison, R., P. Foch and A. Boyer (1989). Coke Quality and Production, Second - Edition, Butterworths, Boston, Massachusetts. 

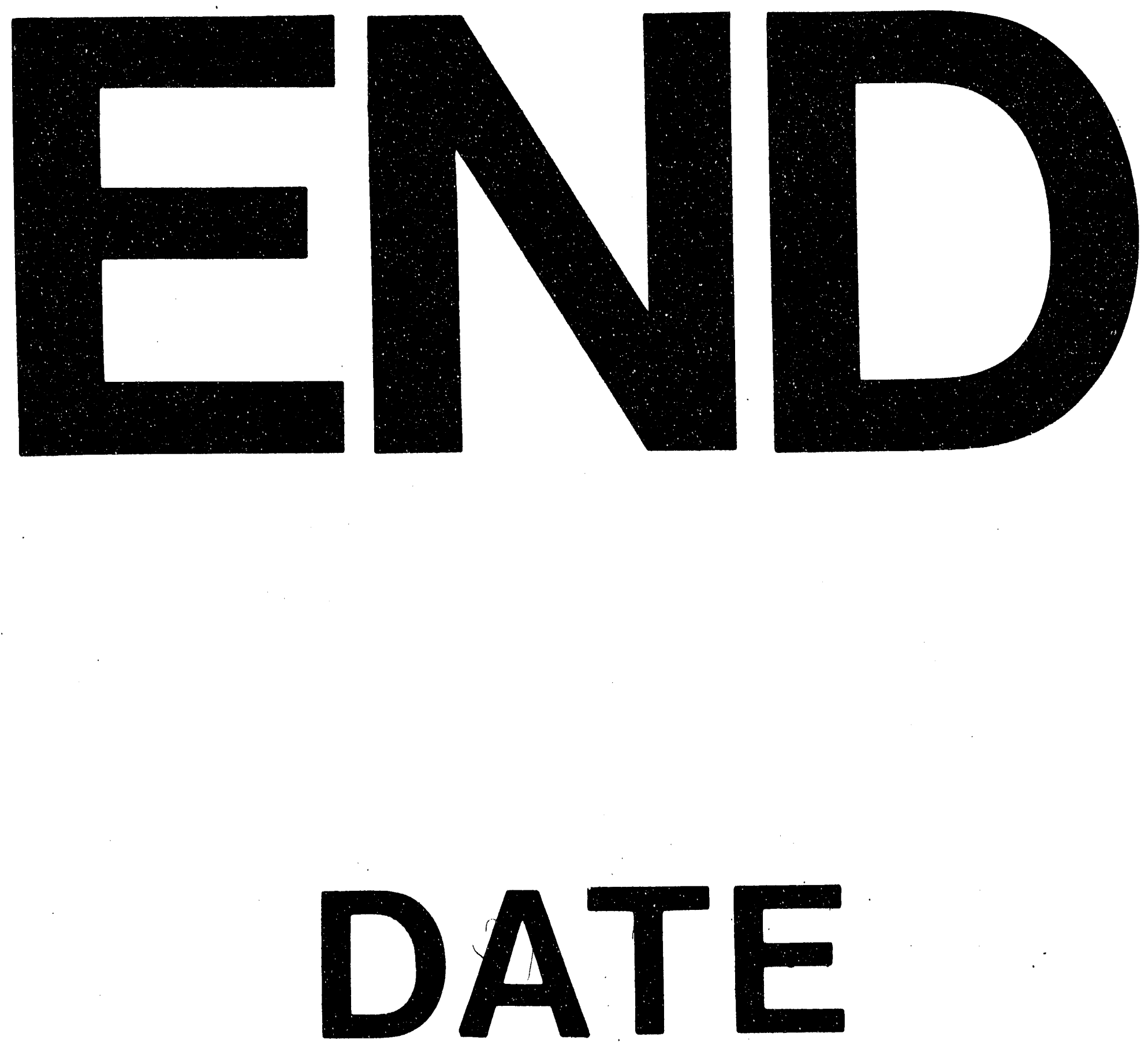

1
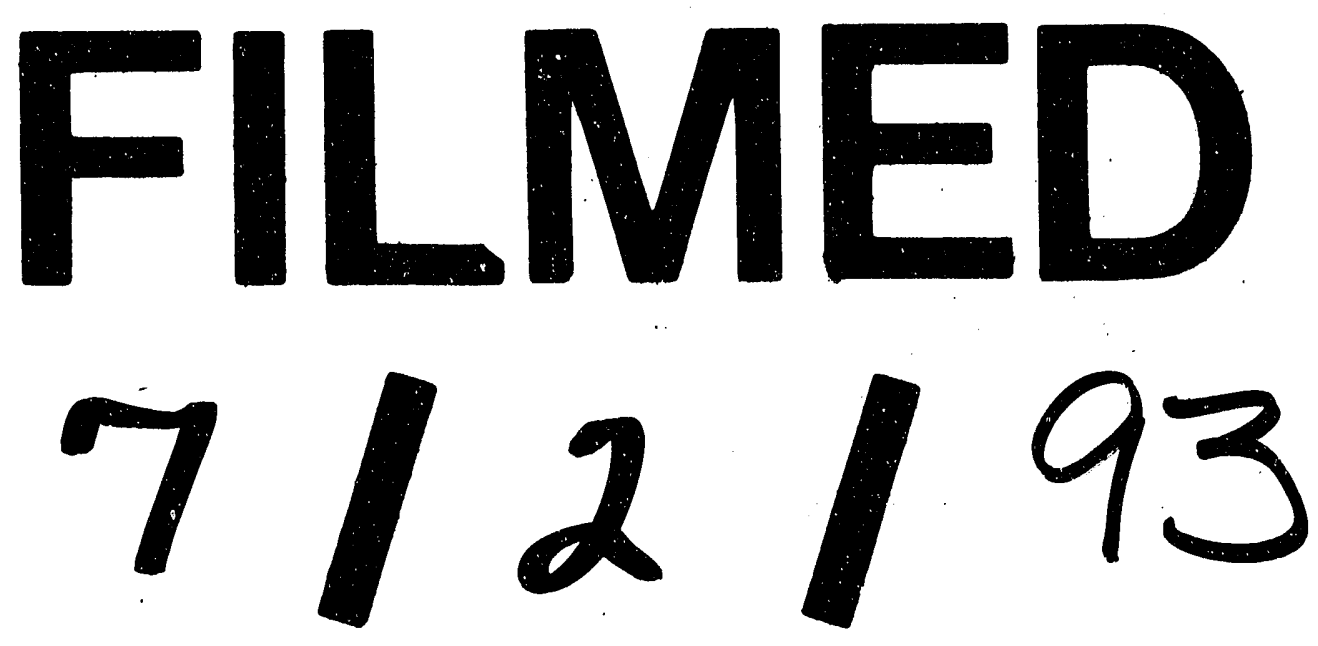
